\title{
Kernos
}

Revue internationale et pluridisciplinaire de religion grecque antique

$10 \mid 1997$

Varia

\section{Epigraphic Bulletin for Greek Religion 1993-1994}

\section{Angelos Chaniotis and Eftychia Stavrianopoulou}

\section{OpenEdition}

\section{Journals}

\section{Electronic version}

URL: http://journals.openedition.org/kernos/666

DOI: 10.4000/kernos.666

ISSN: 2034-7871

\section{Publisher}

Centre international d'étude de la religion grecque antique

\section{Printed version}

Date of publication: 1 January 1997

Number of pages: 249-314

ISSN: 0776-3824

\section{Electronic reference}

Angelos Chaniotis and Eftychia Stavrianopoulou, « Epigraphic Bulletin for Greek Religion 1993-1994 », Kernos [Online], 10 | 1997, Online since 12 April 2011, connection on 16 September 2020. URL : http:// journals.openedition.org/kernos/666 


\section{Epigraphic Bulletin for Greek Religion 1993-1994}

\section{$(\boldsymbol{E B G R})$}

From the first publication of $E B G R$ in 1991 the chronological gap between the publication of a book or an article and its presentation in this bulletin has been relatively long, i.e., four years. In this issue we will begin an attempt to reduce it. The seventh issue of $E B G R$ presents the publications of 1993, part of the publications of 1994, and several addenda to EBGR 1991-1992. Several publications of 1992 and 1993, which unfortunatelly were not accessible on time, will be presented in the next issue.

The principles explained in Kernos, 4 (1991), p. 287-288 and Kernos, 7 (1994), p. 287 also apply to this issue. As usual, works devoted exclusively to aspects of Greek religion (marked with an asterisk) are presented very briefly. The abbreviations used are those of L'Année Pbilologique and the Supplementum Epigraphicum Graecum. We are very much obliged to Oliver Hoover, M.A., for improving the English text.

\section{Additional abbreviations}

Accounts Lewis:

$A E M T, 4:$

AEMT, 5:

Ancient Macedonia V:

Apbieroma Vanderpool:
R. OSBORNE - S. HORNBLOWER (eds), Ritual, Finance, Politics: Atbenian Democratic Accounts Presented to D.M. Lewis, Oxford, 1994.

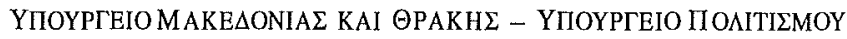

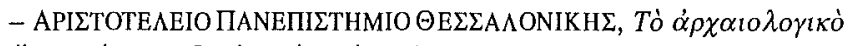

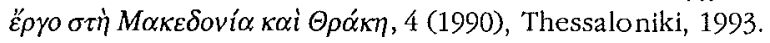

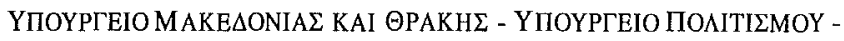

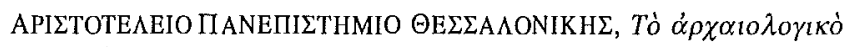

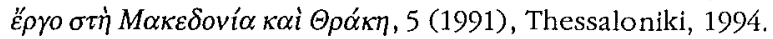

Ancient Macedonia V. Papers Read at the Fifth International Symposium Held in Tbessaloniki, October 10-15, 1989, Thessaloniki, 1993.

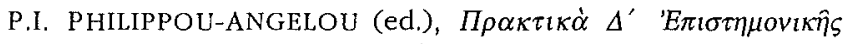

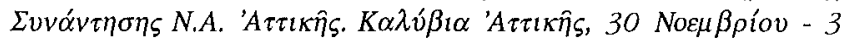
$\triangle \varepsilon \kappa \varepsilon \mu \beta \rho i ́ o v ~ 1989$. 'A

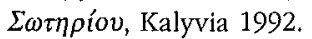


Ariadne:

Boeotia Antiqua IV:

Les bois sacrés.

Cappadoce:

$D T$ :

Eiforscbung Kleinasiens:

Grandi santuari:

Héracles:

L'Illyrie:

I.Ko.Ko:

Lykien-Symposion:

Orfeo:

Rupes loquentes:

Sculpture:

Self-Definition:

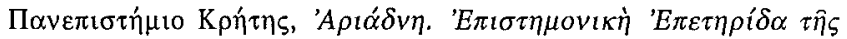

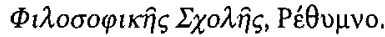

J.M. FOSSEY - J. MORIN (eds), Proceedings of the 7 th International Congress on Boiotian Antiquities (Boeotia Antiqua IV), Amsterdam, 1994.

Actes du colloque International organisé par le Centre Jean Bérard et l'École Pratique des Hautes Études, Naples, 23-25 novembre 1989, Rome, 1993.

B. LE G UEN-POLLET - O. P ELON, La Cappadoce méridionale jusqu'à la fin de l'époque romaine. État des recherches. Actes du Colloque d'Istanbul, 13-14 avril 1987, Paris, 1991.

G. AUDOLLENT, Defixionum Tabellae, Paris, 1904.

G. DOBESCH - G. REHRENBÖCK (eds), Die Epigrapbiscbe und altertumskundlicbe Erforscbung Kleinasiens: Hundert Jabre Kleinasiatische Kommission der Österreichiscbe Akademie der Wissenschaften. Akten des Symposiums vom 23. bis 25. Oktober 1990 (TAM, Ergänzungsband 14), Wien, 1993.

A. MASTROCINQUE (ed.), I grandi santuari della Grecia $e$ l'Occidente, Trento, 1993.

C. BONNET - C. JOURDAIN-ANNEQUIN (eds), Héraclès d'une rive à l'autre de la Méditerranée. Bilan et perspectives. Actes de la Table Ronde de Rome, 15-16 septembre 1989, Bruxelles-Rome, 1992.

P. CABANES (ed), L'lllyrie méridionale et l'Epire dans l'antiquité. II. Actes du II colloque international de ClermontFerrand (25-27 octobre 1990), Paris, 1993.

A. BERNAND, De Koplos à Kosseir, Paris, 1972.

J. BORCHHARDT - G. DOBESCH (eds), Akten des II. Internationalen Lykien-Symposions, Wien, 6.-12. Mai 1990 (TAM, Ergänzungsband 17), Wien, 1993.

A. Masaracchia (ed.), Orfeo e l'orfismo. Atti del Seminario Nazionale, Roma-Perugia 1985-1991, Roma, 1993.

L. GASPERINI (ed.), Rupes loquentes. Atti del Convegno internazionale di studio sulle Iscrizioni rupestri di età romana in Italia, Roma-Bomarzo 13-15. X. 1989, Roma, 1992.

O. PALAGIA - W. COULSON (eds), Sculpture from Arcadia and Laconia. Proceedings of an International Conference beld at the American School of Classical Studies at Atbens, April 10-14, 1992, Oxford, 1993.

A. BULLOCH - E.S. GRUEN - A.A. LONG - A. STEWART (eds), Images and Ideologies: Self-Definition in the Hellenistic World, Berkeley, 1993. 


\section{Selected Topics}

Geograpbical areas (in the sequence adopted by $S E G$ )

Attika: 3. 13. 14. 35. 37. 38. 39. 78. 88. 93. 96. 98. 103. 104. 107. 109. 113. 131. 134. 159. 169. 182. 184. 187. 198. 199. 208. 215. 220. 227. 236. 241. 268. 269. Aigina: 43. 123. 270. Peloponnesos: Korintbia 126. 127. 219. 228. 254; Argolis 176. 189. 216. 228; Epidauros 59. 191. 221. 231. 265. 266. 267; Lakonia 211. 233. 235; Messenia 55. 239. 240; Arkadia 102. 239; Eleia 180. 197. 280; Olympia 43. 90. 252; Achaia 141. Boiotia: 134. 149. 215. 220. 224. 244. Delphi: 7. 15. 43. 215. 257. 259. Aitolia: 122. Doris: 163. Loktis: 163 . Thessaly: 58. 62. 104. 110. 166. 244. 250. 251. 254. Epeiros: 8. 48. 62. 210. 253. 254. 276; Dodona 207. Macedonia: 1. 2. 4. 5. 21. 40. 41. 42. 63. 87. 89. 100. 114. 147. 157. 173. 178, 179, 188, 190. 196, 202. 203, 242. 249. 258. 260, 261. 262, 263. 264. Thrace: 68. 89. 94. 95. 138. 177. 209. North Shore of the Black Sea: 245. 246. Delos: 186. 193. 194. 259. Rhodes: 13. 136. Lesbos: 140.157 . Kos: 219. Cyclades: 93. 150. 236. Samos: 152. Lemnos 181. 182. Samothrake: 68. 94. 105. Euboia: 220. Crete: 30. 35. 47. 49. 73. 154. 156. 185. 230. 238. Sicily: 10. 11. 12. 29. 90. 119. 121. 151. 152. 230. Sardinia: 281. Italy: 16. 31. 45. 46. 76. 90. 91. 92, 117. 243. 277. Gaul: 53. Asia Minor: 32. 33. 34. 94. 101. 157. 167. 189. 216. 217; Karia 20. 23. 24. 57. 73. 105. 161. 165. 192. 195. 201. 226. 255. 256; Ionia 25. 54. 66. 69. 70. 71. 85. 99. 100. 113. 132. 206; Lydia 26. 111. 112. 133; Troas 124; Mysia 146. 216. 217. 236. 244. 259; Bitbynia 44. 153. 237; Pontos 80. 148. 153; Galatia 153; Pbrygia 146. 167. 247; Pisidia 27. 56. 118. 167. 168; Pamphylia 174. 175. 216; Lykia 27. 28. 67. 84. 97. 144. 164. 183. 204. 205. 218. 222. 225. 273. 274. 279; Lykaonia 72; Kilikia 82. 213. 214. 216. 278; Kappadokia 81. Cyprus: 9. 35. 64. 65. 106. 170. 171, 172. 275. Kommagene: 6.61. 83. Syria: 212. Egypt: 18. 19. 22. 36. 51. 77. 79. 115. 116. 128, 129. 130. 135. 143. 155. 160. 248. Nubia: 17. North Africa: 142. Kyrene: 45. 60. 75.121

abstinence: 59

agons: 113. 167; agonistic curses: 52. 125. 126; agonistic inscriptions: 25. 62. 134. 232; hieronikai: 153

agons, in Angeira 27; Aphrodisias 201; Arykanda 205; Beroia 87; Epidauros 219; Euromos 73; Kos 219; Larisa 276; Side 174; provincial agons 201. 219; Agrippeia (Kos) 219; Aktia in Nikopolis 62. 201. 219. 276; in Damaskos 201; in Kaisareia Stratonos 201; Aleaia (Tegea) 240; Ampbiaraia (Oropos) 134; Antonieia Panathenaia (Athens) 131; Antoneia Severeia, in Mantineia 25; in Kappadokia 25; (Agon) Apolloneios Gordianeios Antoneinios (Side) 174; Apollonia (Myndos) 219; Apollonia Isopytbia (Hierapolis) 25; Arcbegesia (Halikarnassos) 219; Artemisia (Ephesos) 132; Asklepieia in Epidauros 219; in Kos 219; Aspis (Argos) 219; Augusteia (Tralleis) 201; Barbilleia (Ephesos) 25; Delia (Tanagra) 240; Dia Haleia (Philadelpheia) 201; Didymeia (Miletos) 25; Eleusinia in Athens 219; in Taras 25; Doreia (Knidos) 219; Eleutheria in Larisa 240; in Plataiai 240; Ephesia (Ephesos) 25. 201; Epibaterios Agon (Side) 174; Eusebeia (Puteoli) 25; Hadriana Olympia (Smyrna) 25; Hadrianeia (Ephesos) 25; Halieia (Rhodos) 25. 136. 240; Hekatesia (Stratonikeia) 219; Heraia (Argos) 240. 277; Herakleia (Iasos) 219; Herakleia Kommodeia (Tyros) 201; Hermeia (Kos) 219; Istbmia 126. 219. 240; Itbomaia (Messene) 239; Kaisareia in Halikarnassos 219; in Kos 219; in Metropolis 219; in Patrai 219; in Sardeis 219; Kapitolia 219; Klaria 25. 219; Komodeia (Miletos) 25; Lykaia 239. 240; Mystikos Agon (Side) 174; Nemea 219. 239. 240; Olympia: 10. 90. 121. 201. 219. 280; in Ephesos 25; in Larisa 240; in Prousa 44; in Tralleis 25; Olympia Komodeia 
(Sparta) 25; Panatbenaia 25. 240; Phoibeios (Side) 174; Pytbia in Delphi 10; in Hierapolis 201; in Laodikeia 201; in Larisa 240; in Megara 240; in Tralleis 25; in Prousa 44; Pytbia Olympia (Side) 174; Rbomaia in Aigion 240; in Chalkis 240; in Kos 219; Rbomaia Sebasta (of Asia) 219; Sarapieia (Tanagra) 224; Sebasta (Neapolis) 25; Sebasteia (Argos) 25; Sebereia Koina Asias (Sardeis) 25; Theogamia (Nysa) 219; Traianeia (Pergamon) 25

afterlife: 146.153 .184

agermos: 219

altar: 5. 23, 44. 54. 68, 70, 81. 82, 83. 93. 97. 114. 132, 146. 151. 153. 163. 172. 174. 188. 205. 213. 219. 222. 238. 240. 258; domestic altar: 219. 222

amphictiony: 54 (Ionian Koinon)

amulet: 51.52 .148 .158 .234

anatomical votive: 78.167

ancestors, cult of: 29.121; mythological ancestors: 219.267

angels: 127

animals: bull 45; eagle 42.72 .178 ; lion 72 ; see also sacrificial animals

anointing: 121

aparche: 105

apotropaic objects, symbols, words: 51. 52. 139.156. 223; see also amulets, gems

aretalogy: 59

arkteia: 60

aspersion: 121

associations: 10. 11. 13. 14. 18. 26. 42. 44. 116. 132. 146. 153. 155. 171. 182. 185. 193. 209.

219. 242; see also Greek words

asylia: 175.205 .213 .214 .219 .278 ; asylon: 68

baetyls: 253

banquet: 73.87 .89 .93 .151 .192 ; see also theoxenia

benediction: see wishes

birthday: 192. 219

burial, within the city: 195

calendar: 64-65 (Cyprus). 107 (Athens). 166 (Thessaly). 219 (Halikarnassos, Kos). 244 (Kyzikos)

cave: 45.151 .281

cenotaph: 8

Christianity: $15.51,52.53 .127,146,158,160,167$

colonists, colonization: 142. 182. 244

confession inscriptions: 167.236

crown: 23. 121. 132. 219

cult: introduction of cults: 68; cult of mortals: 259 (Diodoros Pasparos); see also deification, deities, emperor cult, foundations, mystery cult, relics, ritual, ruler cult

cult objects: cult image: 121. 239; lamp: 164; perirrhanterion: 231. 265; see also altar, statue; Greek words

cult personnel: priests: 21.23 .44 .69 .80 .104 .110 .124 .132 .146 .174 .196 .205 .214 .219 ; accumulation of offices 205. 219; appointment 3; dress 219; eponymous 28. 73. 135. 151. 166. 240. 258. 264; families of priests 153; bereditary priestboods 3. 28. 153. 211. 219; for life 56. 174. 201. 205. 219; lists of priests 4; pentaeteric priests 174. 205; perquisites 219. 258; sale of priesthoods 219; successive terms 153; other cult personnel: agonothetes 5. 44. 56. 153. 168. 201. 219; akrobates 71; ampbipolos 151; archiereia of the civic emperor cult 5. 56. 192. 195. 255; of the provincial emperor cult in Asia 33, 85; in Lykia 205; in Macedonia 5; arcbiereus of the civic emperor cult 25. 44. 56. 128. 153.168. 
192. 201. 219. 240; of the provincial emperor cult in Achaia 228; in Asia 32-34. 85. 112. 146; in Lykia 144. 204. 205; in Macedonia 5; in Pontos: 148. 153; arcbiskeptouchos 132; asiarcbes 33. 85. 111; dadouchos 3. 164; diakonos 69; epimeletes bieron 219; errephoroi 88; bierokeryx 132; bieronomos 124; bierophantes 3. 110 ; bieropoios 87.219 ; biphiereia 219 ; kanepboros 88.219 ; kistiokosmoi 240; kleidophoros 174; kleidouchos 219; kolakretai 269; kynegos 4; mystarches 153; neopoiai (neopoioi) 73. 132. 219; neokoros 219; oikonomoi bieroi 201; periaktria 60; prostates 116. 240; pythaistai 88; sebastopbantes 44; spondopoios 132; theokolos 180; see also Greek words

curse, defixio: 1. 10. 29. 50. 51. 52. 103. 121. 125. 153. 193. 219; see also funerary imprecation

death: 22. 44. 57. 121. 146. 153. 174. 219. 281; as harbour: 44

dedication: 29. 42. 43. 44. 78. 80. 86. 88. 90, 91. 146. 149. 151. 159. 179. 215. 217. 219. 236. 252. 257; dedicatory formulas: 86 ; see also anatomical votive, Greek words

defixio: see curse

deification: 131 (Antinoos). 219 (Caesar); see also cult of mortals, heroic honours emperor cult, ruler cult

deities: Adrasteia: 219. Agathe Tyche: 84. 153, 241. 251. 268. Agathos Theos: 102. 250. Amphiaraos: 134. Anna: 151. Antinoos: 131. Antiphamos 10. Aphaia: 43. 123. 270. Aphrodite: 16. 44. 45. 64. 84. 99. 100. 102. 146. 153. 162. 174. 180. 201. 209. 229. 253; Anassa 64; Golgia 64; Mychoia 64; Pandemos 219; Papbia 64. 171; Polyainetos 132; Pontia 219. Apollon: 24. 28. 38. 44. 54. 60. 64. 84.87. 88. 89. 101. 129. 150. 151. 170. 174. 205. 209. 231. 245. 253. 254. 258; Agyieus 64. 253; Amyklaios 64; Archegetes 219; Dapbnepboros 64; Daphnousios 237; Dekadryos 21; Delios 219; Didymeus 219; Heleitas 64; Hylates 35. 64; Kalymnios 219; Karneios 219; Keraiates 106; Kerdoios 166; Leonteios 44; Lermenos 167; Lykeios 185; Megistos 64. 129; Probegetes 164; Prostaterios 132; Ptoieus 215; Thawasios (?) 170. Areiai: 69. Ares: 69. 84. 131. 167. 174. 205; Aniketos Axoumites 17. Artemis: 28. 44. 45. 64. 71. 84. 104. 110. 146. 167. 176. 178. 192. 205. 209. 210. 219. 235. 253; Chor(e)ia 231; Agrotera 40. 41. 64. 178; Eileitbyia 250; Eleutbera 97 (cf. 28); Ephesia 70. 132; Euktea 153; Hiakynthotrophos 219; Katagogis 60; Kombike 205; Kratiane 153; Kynegetis 279; Lemnia 181; Pergaia 97. 219. 222; Pboibe 74 (?); Pbosphoros 68 (?); Pytbia 260 (?); Skopelitis 185; Soteira 70. 102; Stratia 250; Thausike 97; Thrasenike 205; Throsia 110. Asklepios: 30. 39. 44. 55. 59. 60. 64. 84. 88. 148. 166. 174. 191. 219. 236. 258. 264. 266. 278; see also Epidauros; Kaisar 219; Prokatbegemon 219; Soter 80. 179. 267. Athena: 10. 24. 44. 60. 64. 84. 131. 145. 148 (?). 162.174. 212. 253. 254; Athenon medeousa 219; Boudeia 244; Boulaia 174 (?); Ilias 124; Kyparissia 240; Lindia 219 (cf. Athenaistai Lindiastai); Nike 120. 219; Pbatria 219; Polias 3. 48. 80; Politis 148 (?); Soteira 80. 88. 219. Belchanos: 64 (cf. Belchania). Boule: 132. Charites: 104. 119. 219. Darron: 147. Demeter: 44. 45. 64. 65. 84. 93. 110. 153. 162. 174. 190. 219. 230. 235; Anarsitike 174; Karpophoros 219; Thesmophoros: 10. Demos: 148. 153. 219. Despoina: 239. Dikaion: 44. Dikaiosyne: 44. Diktynna: 73 (?). 233. Dione: 48 . 254. Dionysos: 9. 11. 41. 44. 45. 60. 64. 68. 84. 88. 98. 131. 153. 166. 171. 174. 196. 198. 209. 213. 219. 227. 241. 242. 250. 253; Agrios 110; Choreios 231; Erikryptos 110; Lenaios 64; Lysios 88; Pseudanor 110; Sikytes (?) 64; Thyllopboros 219. Dioskouroi: 45. 73. 84. 164. 211. 219. Dodeka Theoi: 67. 84. 97. 219. 241. 279. Eileithyia: 30. 88. 219; $c f$. 235. 250. Eirene: 44. 219. Eleuthera: 28. 97 (Artemis). 218. Enyo: 12 (?). Epione: 219. Eros: 44. Eueteria: 219. Eukleia 202. 203. Eumenides: 121. Ge: 87. 246. 247; Kyria 153. Hades: 44. 
Hegemone: 239. Hekate: 84. 146. 167. 219. Phosphoros 68 (?). Helena: 166 (?). Helios: 44. 80. 84. 87. 146. 153. 164. 174. 205. 219. 246. 247; Ktistes 267; Kyrios 213; Pangonos 267. Hemera: 219; Hephaistos: 35. 84. 174. Hera: 10. 64. 84. 145. 153. 205. 209; Olympia 219; Ourania 219; Teleia 219 (?). Thespis 152 (?). Herakles: 10. 44. 80. 84. 87. 91. 93. 142. 145. 153. 154. 174. 178. 182. 189. 193. 205. 219. 242. 253. 269. 275; Ampbidexios 64 (?); Diomedonteios 219; Kallinikos 219; Krateropbron 151; Kynagidas 4. 110. Hermaphroditos: 219. Hermes: 41. 44. 64. 80. 84. 87. 96. 153. 193. 205. 219. 242. 248. 253; Chtbonios 250. 251; Kyllenios 219; Enagonios 219; Meletenos 44; Probakchos 219; Probegetes 164. Hestia: 84. 162. 219. Prytaneia 80. Homonoia: 219. Horai: 219. Hosion kai Dikaion: 44. 146. 167; Endemon 146. Hydrechoos: 80. Hygieia: 39. 44.80. 148. 174. 219. 258. 278. Iatros: 60. Kabeiroi: 84. 94. Kalliteknia Sebastou: 73. Klea: 174 . Kore: 93.110 .153 .219 . Korybantes: 219 . Kronos: 83 . Leukaspis: 104. 152 (?). Leto: 28. 84; Pbytia 47. Leukothea: 80. 250. Ma: 110. 178. Maia: 151. Megaloi Theoi (of Samothrake): 68. 94. 105. 219; see also Kabeiroi. Mes: 167. 246. Messene: 55. Meter: 69. 133. 178. 167; Dindymene: 44; Kiklea 146; Megale 47; Makaria Hosia Dikaia 146; Oreine 146 (Oriene); Thea 146. Meter Theon: 14. 47. 53. 80. 88. 110. 153. 188. 191; Zingotene 146. Meteres: 151. 230. 235. Mneme: 219. Moirai: 219. Muses: 201. 219. Nemesis: 44. 113. 174. 205. 219. Nike: 44. 120. 219. Nikeros: 219. Nymphs: 28. 30. 64. 66. 74. 80. 84. 94. 151. 174. 212. 219. 250. 253. Ouranos: 229. Ourios: 219. Paides: 151. Pan: 44. 45. 84. 130. 209. 219. Parthenon: 28. Parthenos: 24. 178. Peitho: 219. Persephone: 45. 230. Podaleirios: 219. Poseidon: 3. 17. 41. 44. 84. 126. 209. 219. 253. 254. 261. 262; Asphaleios 174. 219; Erechtheus 3; Helikonios 80; Hippios 219; Istbmios 219; Patragenes 251. Priapos: 219. Rhea: 47. 219; Sebaste 219. Roma: 28. 32. 44. 174. 205. 213. Seirios: 80 . Selene: 44.80. Telesphoros: 44. Tetralea: 151. Thanatos: 44. Thea: Epekoos 146; Patroa 236; Syria Parthenos Gyrbiatissa 178. Themis: 80. 174. Theoi: 219; Agreis / Agroteroi 84; Agrioi 164; Basileis 167; Katachtbonioi 153; Pantes 268; Patrioi 219; Soteres 219; see also Dodeka Theoi. Theos: 146; Aneiketos Absameus 153; Atbanatos 153; Doumouisenos 153; Epekoos 146; Epekoos Hypsistos 146. 153; Heros 179; Heros Mestenos 179; Megas Megas Hypsistos 248; Hypsistos 146. 153. 172. 219. Kteision Epekoos 153; Megas 205; Megas Hypsistos 80; Monios 153; Somendeus 205. Tritopatores: 121. Tyche: 44. 153. 162. 229; see also Agathe Tyche. Zeus: 17. 45. 46. 64. 76. 80. 82. 84. 87. 146. 153. 167. 174. 179. 207. 217. 219. 229. 241. 243. 247. 252. 263; Abozenos 167; Akraios 254; Alseios 219; Atabyrios 219 (Diiatabyriastai); Baleos 153; Basileus 219; Basilikos 44; Bennios 146; Boulaios 253; Brontaios 153; Bronton 44. 146; Dikaiosynos 80; Dodonaios 254; Epekoos 153; Epidemios 82. 153; Epikarpios 153; Epouranios 219 (?). Euboulos 93; Eumenes 121; Gainios 153; Halonites 174; Hikesios 219; Hypsistos 41. 44. 78. 178. 219; Itbomatas 240; Karzenos 153; Kerdylas 217; Kersoullos 217; Kimistenos 153; Koropizos 153; Kretagenes 73; Kronides 42; Labraundos 217; Lepsynos 73; Meilichios 20. 41. 121. 203. 251; Naios 10. 48; Nemeios 219; Nikator 174; Nineudios 226; Norites 174; Olybreus Epekoos 213. 217; Olympios 44. 108. 151. 213. 219; Patroos 219; Panamaros 217; Philios 2 (?). 219; Pbratrios 2 (?); Poarinos 153; Polieus 219; Sarsos 153; Sdaleites 153; Soter 73. 88. 164. 219. 253; Strategos 153; Thallos 167; Theos 213; see also agon, cult, festival

deities: Anatolian: 44. 97. 146. 153. 164. 167. 174. 205. 213. 217. 226. 279; Agdistis 199; Attis 199; Groustene (?) 44; Kybele 44-46. 63. 162. 174. 199. Egyptian: 18. 31.41. 44. 79. 80. 84. 93. 129. 130. 132. 153. 155. 162. 174. 183. 192. 205. 213. 214. 219. 
242. 248. 249. 256; Oriental: Dea Syria 178; Melqart 142. 275; Mithras 72.83. 146. 164; Baal 219. Roman: 142. 162. 193. 209. 210. 219. Thracian: 94. 95. 177. 179. 209; Bendis 235; see also rider god

deities, identifications with kings, emperors, statesmen: 38 (Nero - Apollon). 131 (Marc Antony - Neos Dionysos, C. Caesar - Neos Ares); 219 (Agrippina - Demeter Karpophoros, Augustus - Zeus Patroos, Claudius - Zeus Soter); protectors of fertility: 121. 176; protectors of justice: 73.167 ; protectors of military units, citywalls, et sim.: 219. 256; protectors of navigation: 174 . 219 ; river god 45

disease: 22. 51. 52. 132. 234. 236; see also healing

divination: 15.93 ; divinatory charms: 52 ; see also dreams, oracles

dream: 15.52 .151 .185 .236 .250

dress: 110.219

eiresione: 88

Eleusis, Eleusinian cults: 3. 88. 131

emperor cult: 5. 25. 32. 33. 34. 37. 38. 44. 70. 73. 77. 80. 84. 85. 111. 112. 128. 131. 132.

144. 146. 148. 153. 162. 163. 167. 168. 174. 175. 192. 195. 201. 204. 205. 219. 228.

238. 240. 255; identification of emperors with gods: see deities

envy: 139.223

Etruscans: 43. 123. 270

evil eye: $57,139.219$

family: 121.219 ; see also ancestors, genos

festivals: in Aphrodisias 201; in Arykanda 205; in Kos 219; in Samothrake 105. 219; in Ptolemaic Egypt 135; Agriania 110; Alseia 219; Ampbiaraia: 134; Antbesteria 198; Asklepieia (Kos) 219; Boudia (Kyzikos) 244; Demostbeneia (Oinoanda) 225: Dionysia in Athens 98. 227; in Chios 219; in Iasos 161. 219; in Kos 219; in Myrina 182; in Samothrake 219; in Teos 205; Dipanamia (Kos) 219; Ekdysia 47; Eleusinia: 88; Epidauria (Athens) 88; Hepbaistieia (Kos) 219; Herakleia (Athens) 93. 269; Hermaia (Beroia) 87; Hiakynthotrophia (Knidos) 219; Klaria 54; Kotytia (Selinous) 121; Nikephoria (Pergamon) 259; Panatbenaia: 88, 219; Peritia 242; Pythais 88; Pytbokleia (Kos) 219; Thaleia (Kos) 219; Thesmophoria (Teos) 205; see also agon, spectacle

footprints: 249

foundations: 132. 201. 219. 225. 236. 255

funerary cult / practices: 8. 44. 56. 72. 81. 93. 114. 146. 148. 153. 173. 176. 195. 197. 205. 218. 242. 281; funerary imprecation: 25.72 .114 .146 .148 .205 .213 .247 .279 ; see also burial, cenotaph, heroic honours

gems: 229. 234; see also amulets

genos: 3 . 121; see also family

ghosts: 121

gold: 121. 219

grove: 35.101 .219 ; see also Zeus Alseios

gymnasium: 62. 87. 219

hair, cutting of: 143

healing: 52. 59. 178. 191. 219. 258; healing deities: 30. 146; see also anatomical votives, deities (Asklepios, Hygieia, Iatros), disease, incubation

heroes: Herakles: 121. 145 (see also deities); Mopsos: 216; Perseus: 189. 216; Telephos: 216; comparison of mortals with Homeric heroes: 153

heroic cults: 45 (Euthymos). 55 (Messene), 104 (Leukaspis), 138 (Auloneites). 176 (Polemokrates). 179 (Mestenos). 187 (heros Archegetes). 251 (heros Oinousseus)

heroic honours (for the deceased): 56. 132. 195. 197. 205. 219. 255. 259

hierodoulos: 219; see also slave 
hiketes: see supplication

homicide: 121

honey: 121

hunting: 35.110

hymn: 52. 191. 219. 266

identity and myth / religion: 55. 122. 189. 216

imprecation: see curse, funerary imprecation

incense: 148.219

incubation: 59.258

initiation: $35.44 .47,110,143.178$

invocation: 128.201 .213 .248

Jews, Judaism: 26. 165. 167. 173

katabasis: 45

lex sacra: 22.60 .69 .73 .76 .104 .121 .148 .182 .219 .243 .258 .268

libation: 108, 121. 219

linen: 44

magic: 49. 50. 51. 52. 58. 74. 75. 79. 103. 125. 137. 148. 156. 234; erotic magic: 51. 52. 74. 125; see also amulet, curse, gem

mallokouria: 143

manumission, sacred: 110.178 .188

month names: see calendar

mountain: 35

mystery cult: 55 (Andania). 72 (Mithraic). 132 (Artemis); see also Eleusis; mystes: 44.153

myth: 55. 111. 122. 153. 189. 216. 217. 259. 281; comparison of the deceased with mythical figures: 153. 281; mythological names: 201 (Xanthos, Patroklos)

names, theophoric: 65 (Thenaos). 157 (Dies). 178 (Materine); mythological: 201 (Xanthos, Patroklos); related to religion: 11 (Mazan, Namonaios). 169 (Noumenios)

Near East, Near Eastern parallels: 75. 121

neokoreia: 34. 85. 112. 174. 175

night, nocturnal rituals: 127. 260; torchlight procession: 219

oath: 75.87 .193

'obscenity': 96.119

olive, olive oil: 106.121

omphalos: 7

oracle: 15. 48. 52. 101. 132. 151. 152. 185. 207. 215. 217. 219; alphabetical o.: 174

Orpheus, Orphic texts, Orphism: 29. 92. 117. 158. 235

paganism, in Late Antiquity: 15. 160. 167

phallophoria: 219; phallus 223

Phoenicians: 75. 121. 142. 275

pilgrimage: 130.151

politics and religion: 103, 113, 122, 155. 171, 189, 215. 216

pollution: 22. 121

prayer: 124.128 .153 .219

priest: see cult personnel

procession: 60.73 .166 .219

proskynema: 130

purification, purity: 22. 45. 59. 73. 121. 219

relics: 122

rider god: 41. 44. 95. 209

rites of passage: see initiation 
rituals: see agermos, anointing, aparche, arkteia, aspersion, banquet, eiresione, honey, incense, katabasis, libation, mallokouria, night / nocturnal rituals; olive oil, phallophoria, procession, purification, sacrifice, salt, water, wedding, wine; see also Greek words (cult)

ruler cult (Hellenistic): Antigonos Doson 219; Antiochos I of Kommagene 6. 51; Apollonis 259; Ariaratbes IV 219; Arsinoe Pbiladelpbos 219; Attalids 259; Attalos III 259; Eumenes II 219; Ptolemies 9. 135.172

sacrifice: 8. 23. 44. 69. 73. 76. 87. 93. 105. 120. 121. 132. 151. 200. 219. 241. 243. 258. 268; sacrificial animals: bull 23; cow 219; goat 200; ox 8. 219; pig 219. 243; piglet 121; ram 121; sbeep 121. 200. 219; sacrificial calendar: 104. 182. 219

sacrilege: 87

salt: 121

sanctuaries: 132. 148. 149. 164. 219. 258; accessibility 178; archives 133; accounts 60. 109; boundary stones 39. 132. 148; extra-urban 35. 101. 151. 167; federal 30. 140 (see also amphictiony); finances 10, 24. 29. 46. 60. 135. 178. 194. 205. 208. 219; foundation 236; inventories 109; nakoreion 219; production in s. 106; property 70. 208. 219; protection of 169. 219; thesauros 71.109 .219 ; see also grove, temple, temenos

slave, sacred (hieros): $71,132.146 .178 .219$; see also manumission

soul: 146

spectacle: 228. 255

sphinx: 36

statues: 21. 149

superstition: see evil eye

supplication: 68.153

syncretism: 6.28.69.84.91.129.135.142. 275

temenos: 39.44 .73

temple, opening of: 219

theoria: 105,219

theoxenia: 93. 121, 219. 227

thesauros: see sanctuary

torch-race: 87.219 ; torchlight procession: 219

trees: 21.35 ; cypress 92; poplar 219

truce: 121.219

war: 120

water: $45.121 .127,212.219$

wedding: 45.60 .219

wine: 75. 121. 138. 166. 192. 198. 219

wishes: 53.111 .146 .229

women: 88. 98. 110. 219

youth: $47.87 .88 .110,143.201 .211 .219$; see also gymnasium

\section{Greek words}

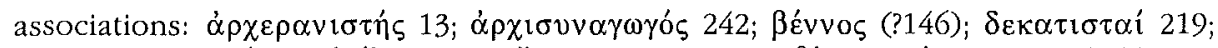

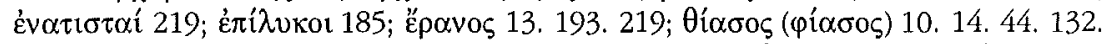

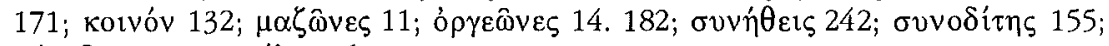

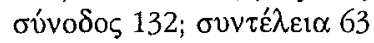

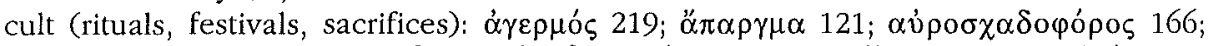

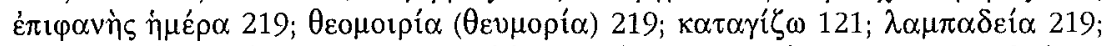

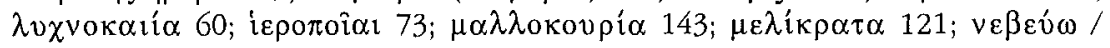




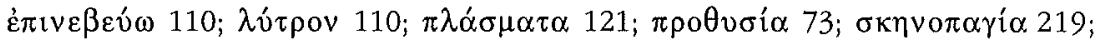

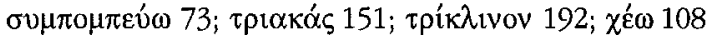

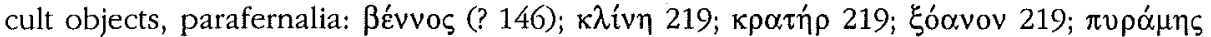

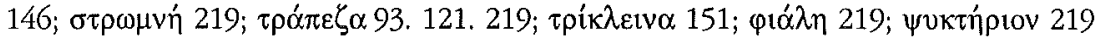

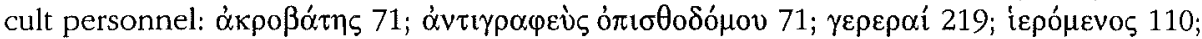

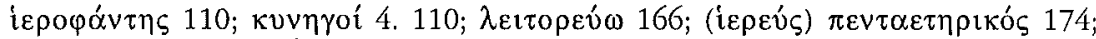

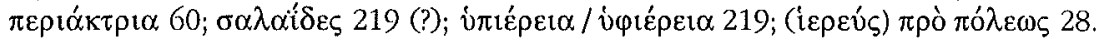
132

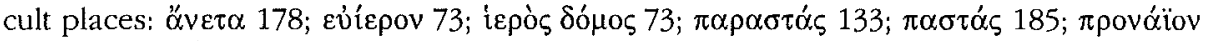
242; то́лоร 18.19

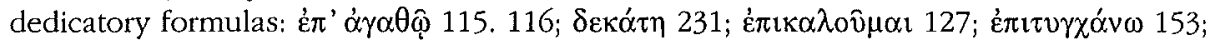

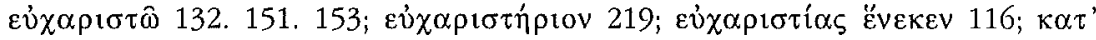

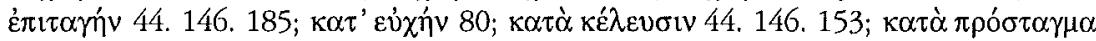

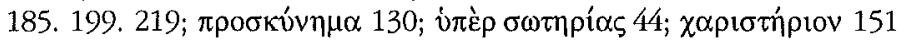

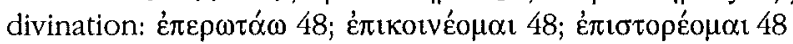

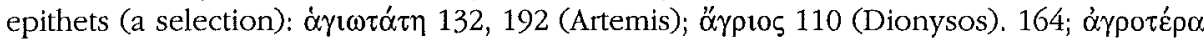

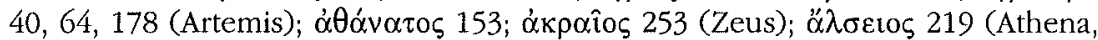

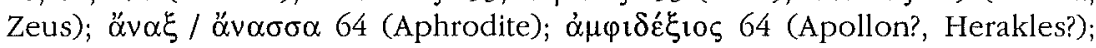

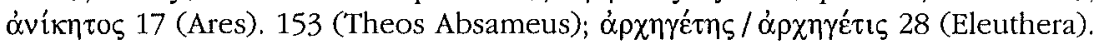

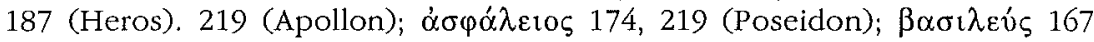

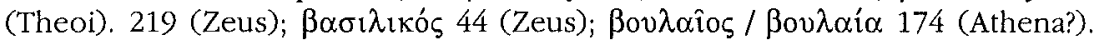
243 (Zeus); Síkalos 146 (Meter); see also deities, Hosion kai Dikaion;

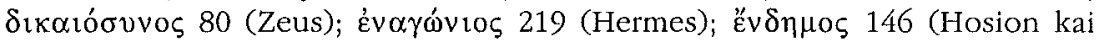
Dikaion); غ̇лі́кoos 44. 146. 147 (Darron). 153 (Helios, Zeus). 174 (Asklepios,

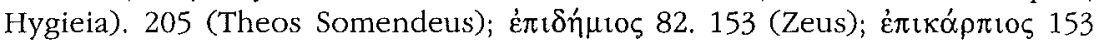

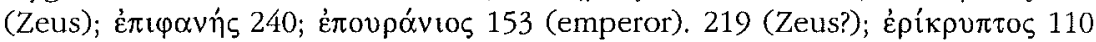

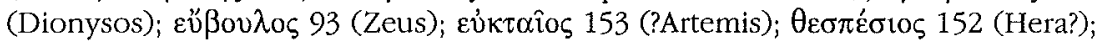

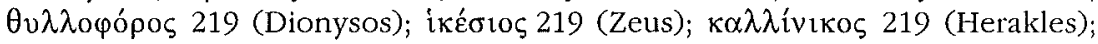

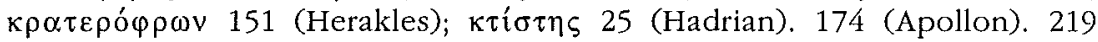

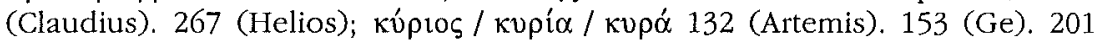

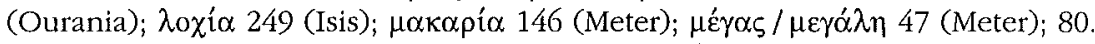

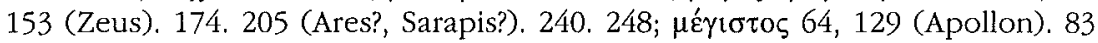
(Kronos). 205 (Theos Somendeus); $\mu v \chi i ́ \alpha 64$ (Aphrodite); vıкó $\omega \omega \rho 174$ (Zeus); ó $\sigma i ́ \alpha 146$ (Meter); see also deities, Hosion kai Dikaion; oủ pavía 219 (Hera);

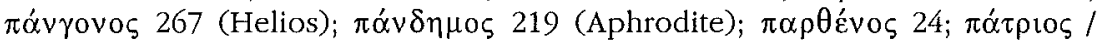
$\pi \alpha \tau \rho \hat{\varphi}$ os 84. 111. 153 (Zeus, Hera). 174 (Apollon, Athena). 219 (Zeus, Theoi).

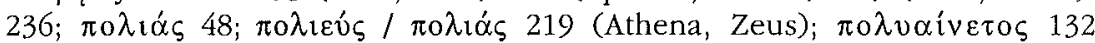

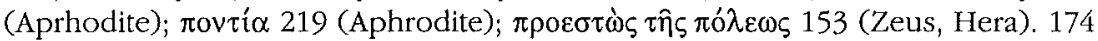

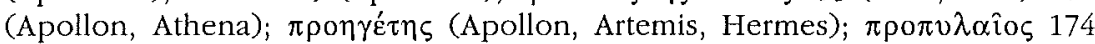

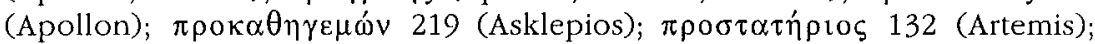

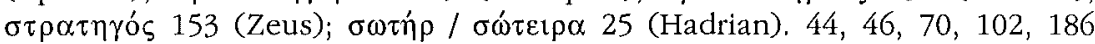

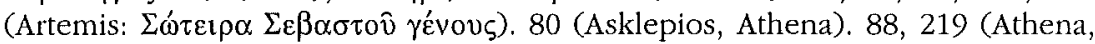
Zeus). 179 (Asklepios). 219 (Apollon Didymeus). 219 (Zeus, Theoi). 253 (Zeus);

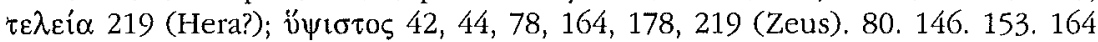

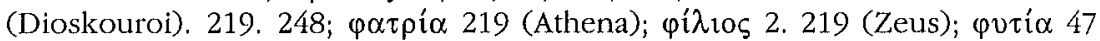

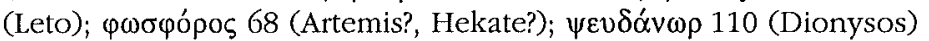

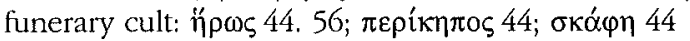

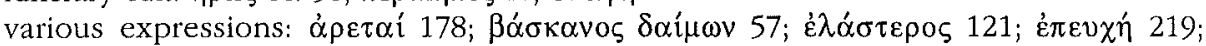

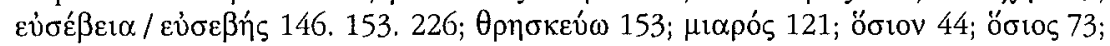
$\varphi \iota \lambda o ́ \theta \varepsilon o \varsigma 153$ 


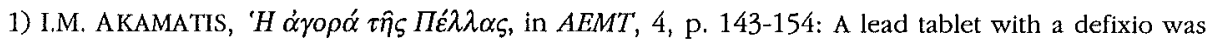
found in a grave in the cemetery southeast of the agora of Pella (ca. $350 \mathrm{BC}$ ); another three defixiones were found in the 'Eastern cemetery' of Pella (p. 148 with note 20). [AC]

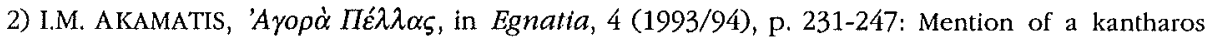
dedicated to Zeus Ph[ratrios] or Ph[ilios] (Pella, Agora, late 4th cent. BC). [AC]

3) S.B. ALESHIRE, The Demos and the Priests: The Selection of Sacred Officials at Atbens from Cleisthenes to Augustus, in Accounts Lewis, p. 325-337: A. discusses the means by which sacred officials were selected in Athens. The epigraphic evidence shows that the gene which provided the hierophantes and the dadouchos of the Eleusinian Mysteries and the priests of (Poseidon) Erechteus and Athena Polias did not fill these priesthoods by allotment as mentioned in the Patmos Lexicon. The hierophantes and the dadouchos were elected by the Eumolpidai and the Kerykes respectively, while the Eteoboutadai transmitted the priesthoods of Poseidon Erechtheus and Athena Polias by inheritance. Yet it is possible that allotment was applied, after a short list had been compiled somehow. This restricted allotment may have been one of the means (or the primary means) of filling gentilician priesthoods in Athens between the fifth century and $21 \mathrm{BC}$. Then the method of appointment for many, if not all, gentilician priesthoods changed, from restricted sortition to direct election probably by the members of the genos which controlled the priesthood. [ES]

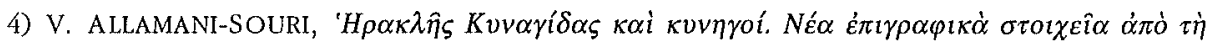

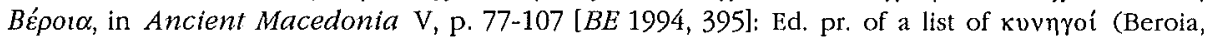
121/20-111/10). The new inscription shows that two kynegoi served as priests of Herakles Kynagidas annually; it is not clear what other function the kynegoi had [cf. infra $\mathrm{n}^{\circ} 110$ ]. The cult of Herakles Kynagidas was epichoric in West Macedonia. The list was inscribed successively, year after year lon such lists of priests and magistrates cf. A. CHANIOTIS, Historie und Historiker in den griechischen Inscbriften, Stuttgart, 1988, p. 186f.]. The sanctuary of Herakles Kynagidas in Beroia may have been closed after the Roman conquest, due to the close connection of the Macedonian dynasty with this cult, and re-established in $121 \mathrm{BC}$, the year in which the present list begins. [AC]

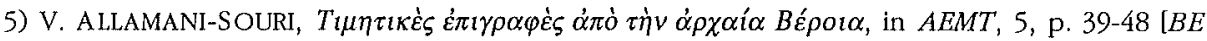
1994, 396]: A.-S. presents two honorific inscriptions from Beroia. One of them was set up for Ti. Claudius Aelianus Alexandros and his wife Avidia Ammia from Astaia (1st/2nd cent.). Alexandros served as agonothetes of the Koinon of the Macedonians and high priest of the provincial emperor

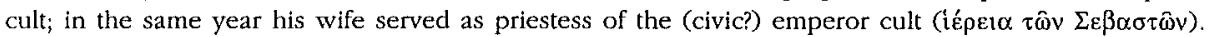
The second honorific inscription was written on an altar erected by the synhedroi of the Macedonian Koinon for Septimia Silvane Kelereine, the daughter of the president of the Koinon (Makedoniarches), Septimius Silvanus Celer, and the high priestess of the provincial emperor cult, L. Aurelia Trevonia Nikomacha (3rd cent.). [AC]

*6) D. ALLGÖWER, Antiocbos Ier de Commagène entre sceptre et diadème, in AION (arcb.), 15 (1993), p. 257-287: The cult reforms of Antiochos I of Kommagene and his religious buildings (hierothesion of Nemrud Dagh, temene) combine Greek and Iranian elements and should be interpreted in the light of Antiochos' royal ideology. [AC]

7) P. AMANDRY, Notes de topograpbie et d'arcbitecture delpbiques. IX. L'opistbodome du. temple d'Apollon, in BCH, 117 (1993), p. 263-283 [BE 1994, 94]: The monument set up in the opisthodome of the temple of Apollon in Delphi, contemporary with the erection of the temple may be either a statue of Apollon dedicated by the amphictiony after the 3rd Sacred War or the omphalos; the accounts of the construction of the temple do not exclude the latter assumption [cf. $E B G R$ 1992, 2]. [AC]

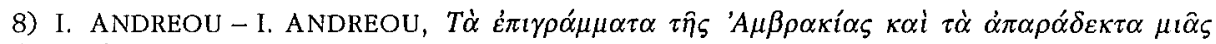

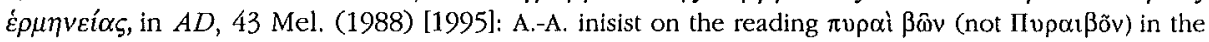
first line of the epigram of a cenotaph excavated in Ambrakia (7th/6th cent.) [EBGR 1991, 5]. The offering of sacrifices of oxen for the Ambrakian warriors buried in the cenotaph can be confirmed by the find of the bones of oxen during the excavation. [AC] 
9) S. ANEZIRI, Zwiscben Musen und Hof, in ZPE, 104 (1994), p. 179-198 [BE 1995, 607]: A. collects the epigraphic testimonia related to the association of the Dionysiac technitai on Cyprus and discusses in detail the organisation of the association and its history. She demonstrates that the Ptolemies played an active part in the foundation of the synod and retained close relations with it (particularly Ptolemy VIII). The prominent position of the synod can be explained in view of the rôle of Dionysos in the dynastic legitimation of the Ptolemies. The synod of the Dionysiac artists was responsible for the musical and dramatic festivals, which played an important part in Ptolemaic selfrepresentation. [ES]

10) R. ARENA, Iscrizioni greche arcaicbe di Sicilia e Magna Grecia. Iscrizioni di Sicilia II. Iscrizioni di Gela e Agrigento, Milano, 1992 [SEG 42, 822]: Collection of the archaic Greek inscriptions of Gela, Akragas, and Kamarina [ $c f$. the corpus of L. DUBOIS: EBGR 1989, 29], with the Greek text, a basic [but not full] bibliography, and some linguistic remarks. Gela: Most dedications are graffiti on vases dedicated to various deities, i.e., Antiphamos (29), Athena (8), (Demeter)

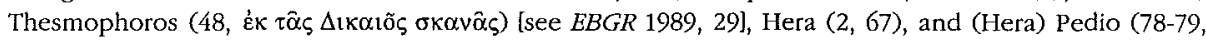

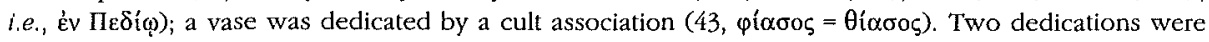
made by Geloan victors in Olympia (4, by Pantares to Zeus) and Delphi (46, by Polyzalos to Apollon). The corpus also includes a few defixiones $(47+80,73$ ?). Akragas: In addition to two defixiones $(90,117)$ I single out an unpublished block, perhaps inscribed with a dedication to Zeus

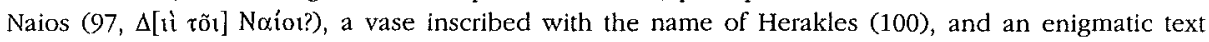
mentioning a debt to a goddess (118). Kamarina: Four defixiones (142-145). [AC]

11) R. ARENA, Le iscrizioni antiche di Gela e Agrigento: problemi di lettura, in Acme, 47 (1994), p. 5-14: The name Mó $\zeta \alpha v$ which appears on a tessera from Kamarina (F. CORDANO, Le tessere pubbliche del tempio di Atena a Camarina, Roma, 1992, $\mathrm{n}^{\circ} 18$ ) is Greek. It is related to the word $\mu \alpha \zeta \hat{\omega} v \varepsilon \xi \varsigma$ which designates a Dionysiac association in Figaleia (IG V 2, $178=D G E 677 \mathrm{~g}$ ). Another

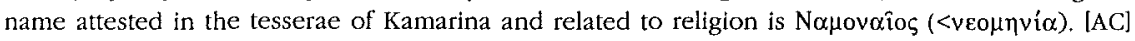

12) R. ARENA, Tra linguistica ed epigrafia, in ZPE, 103 (1994), p. 155-158; A proposes a different reading and interpretation of an archaic inscription from Naxos on Sicily (SEG 35, 1014):

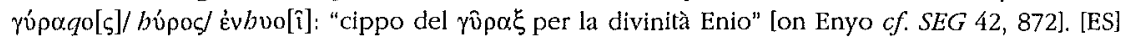

13) I. ARNAOUTOGLOU, APXEPANIETHE and its Meaning in Inscriptions, in ZPE, 104 (1994), p. 107-110: A. examines separately the documents pertaining to the function and position of the $\dot{\alpha} p \times \varepsilon p \alpha v i \sigma \tau)$ in the associations of Athens and Rhodes. While in Rhodes this office was prominent and the archeranistes excercised authority over the fellow ép $\alpha v i \sigma \tau \alpha \dot{i}$, the prominence of the archeranistes in the associative context in Athens is doubtful. [ES]

14) I. ARNaOUTOGLOU, The Date of $I G^{2} 1273$, in $Z P E, 104$ (1994), p. 103-106 [BE 1995, 230]: The only epigraphical testimony for a group of thiasotal worshipping Meter Theon in Athens (IG $\mathrm{II}^{2}$ 1273) should be dated during or after the archonship of Nikias II $(281 / 80 \mathrm{BC})$. An orgeon for the cult of Meter Theon is also mentioned in $I G \mathrm{II}^{2} 1316(246 / 5 \mathrm{BC})$. The different date of the two inscriptions implies either that there were two associations (thiasotai, orgeones) for the cult of Meter Theon in Piraeus in the $3 \mathrm{rd}$ cent. $\mathrm{BC}$, sharing the same facilities, or that the shrine changed hands, from the thiasotai to the orgeones, sometime between $284 / 3$ and $246 / 5 \mathrm{BC}$. [ES]

15) P. Athanassiadi, The Fate of Oracles in Late Antiquity, in Deltion Cbristianikes Archaiologikes Hetaireias, 15 (1990), p. 271-278: After a period of great growth of oracles under the Antonines, in the course of the 3rd and 4th cent. AD the oracles of Didyma and Delphi clearly declined. Divination retained its importance throughout Late Antiquity, but in this period the means of divination were primarily dreams and healing oracles. Despite the decline of the oracular sites, the Christians continued a polemic against oracles, which, however, has an historical relevance only for the period of the Antonines. $[\mathrm{AC}]$

16) M. BARRA BAGNASCO (ed.), Locri Epizefiri. IV. Lo scavo di Marasà Sud. Il sacello tardo arcaico e la "casa dei leoni", Firenze, 1992: The volume presents the results of the excavation in the southern section of the Marasà area, a zone outside the city walls of Lokroi, where a sanctuary of Aphrodite existed from the 7 th to the middle of the 4th cent. BC. A graffito (p. 14), and a dedication 
to Aphrodite (p. 15) permit this identification (p. 14f.). A roof tile bears the stamp iep[ó ] (p. 323). [On these texts cf. EBGR 1990, 18]. [AC]

17) E. BERNAND - A.J. DREWES - R. SCHNEIDER, Recueil des inscriptions de l'Étbiopie des périodes pré-axoumite et axoumite, Paris, 1991 [SEG 42, 1637-1640, 1646, 1655, 1656]: B. gives a new edition of the Greek inscriptions from Axoum, Adoulis, and Meroe, which include the res gestae of Ptotemy III (276, OGIS 54), and res gestae of local rulers mentioning the cult of "ApnS

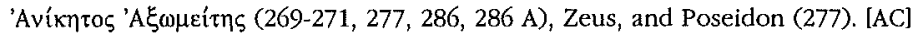

18) E. BERNAND, Un prêtre de la déesse Triphis, in ZPE 96, (1993), p. 64-66 [BE 1993, 686]: Ed.

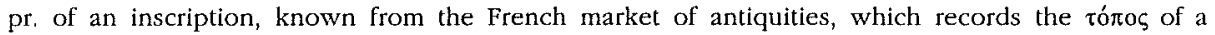
priest of Thriphis. This Egyptian goddess is rarely attested, and it seems that she was worshipped basicaly in Panopolis, the probable provenance of the new inscription. The inscription probably refers to a space (topos) reserved for the priest in the precinct of the goddess or in the building of a cult association [cf. infra $\mathrm{n}^{\circ}$ 19]. [AC]

19) E. BERNAND, Topos dans les inscriptions grecques d'Égypte, in ZPE, 98 (1993), p. 103-110

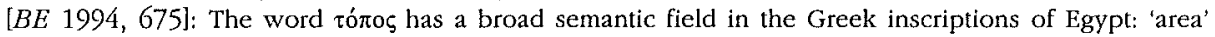
(often in texts referring to grants of asylum), 'building' (often 'sacred building'), 'sacred area', 'space' (often space reserved for associations, artisans, or tradesmen). In contrast to the ancient reader of an inscriptions, who could easily infer the exact meaning of the word from the topographical context, the modern reader often lacks a clue for its interpretation. [AC]

20) F. BERTI, Mission arcbéologique italienne de Iasos. Compre rendu des travaux de 1991, in XIV. Kazi Sonuçlari Toplantisi, Ankara 25-29 mayir 1992, Ankara, 1993, vol. II, p. 91-115 [BE 1994, 530]: A dedication to Zeus Meilichios was found in Iasos (imp., p. 97, fig. 5). [AC]

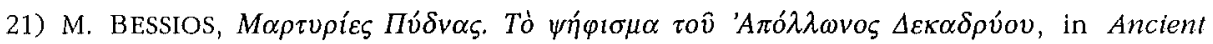
Macedonia V, p. 1111-1121 [BE 1994, 389]: B. presents the transcription of a decree of Pydna (2nd

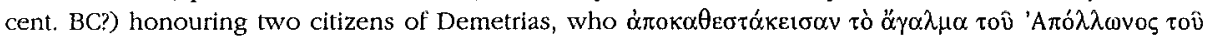
$\Delta \varepsilon \kappa \alpha \delta \rho v 0 v$, at the request of the city. B. suggests that the persons honoured were sculptors who repaired the statue [on the restoration of statues $c f$. SEG 42, 1833]. The new text attests for the first time the cult of Apollon Dekadryos and his temple in Pydna (1. 26f.). The epithet derives from a place name ('the ten oak trees') [cf., e.g., Zeus $\dot{\varepsilon} \kappa \Delta t \delta \dot{\mu} \mu \omega v \Delta \rho v \hat{\omega} v:$ G. PETZL, Die Beicbtinscbriften Westkleinasiens, Bonn, 1994, $\mathrm{n}^{\text {os }}$ 9-12]. The decree was proposed by the priest of Apollon Dekadryos, [This is, however, no evidence for B.'s assumption that he was the eponymous priest of Pydna]. [AC]

22) J. BINGEN, La lex sacra SB I 3451 = LSCG Suppl. 119 (Ptolémaïs, Haute-Égypte), in CE, 68 (1993), p. 219-228 [ $B E$ 1994, 687]: B. discusses a lex sacra from Ptolemais (LSS 119, 1st cent. BC), republished recently - with translation and commentary by A. BERNAND [EBGR 1992, $12 \mathrm{n}^{\circ} 47$ ]. The text concerns itself with the purity ( $\alpha \gamma v \varepsilon v \dot{\varepsilon} \imath v)$ of those who enter a sanctuary. B. restores several

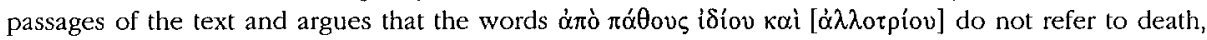
but to disease. His translation, after his restorations, reads: "Ceux qui pénètrent dans le sanctuaire doivent respecter les délais de purification suivant les prescriptions ci-dessous: (pour l'impureté provenant) de sa propre maladie ou de celle d'une autre personne (?), sept jours; d'un décès, $X$ jours; d'un avortement ..., $\mathrm{X}$ jours; d'une accouchée qui allaite, $\mathrm{X}$ jours; si elle s'est séparée de l'enfant, 14 jours; les hommes après des relations avec une femme, 2 jours; les femmes suivent les mêmes prescriptions que les hommes, (cependant, pour l'impureté provenant) d'un avortement, 40 jours; celle qui a accouché et qui allaite, 40 jours; mais, si elle s'est séparée de l'enfant, X jours; pour les menstruations, 7 jours; après des relations avec un homme, 2 jours et elle (apportera?) du myrte." [AC]

23) W. BLÜMEL, Two new inscriptions from the Cnidian Peninsula: Proxeny Decree for Epameinondas and a Funeral Epigram, in EA, 23 (1994), p. 157-159 [BE 1995, 20]: Ed. pr. of a funerary epigram for the priest Phileratos (Knidos, 4th cent. BC). The epigram describes his priestly duties: when offering a sacrifice, he wore a wreath on his head; the most important of these sacrifices was the sacrifice of bulls offered to the immortal gods for the people of Knidos; the thighs of the

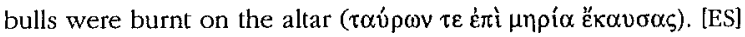


24) W. BLÜMEL, SGDI 5727 (Halikarnassos): Eine Revision, in Kadmos, 32 (1993), p. 1-18: Republication, with new readings, of an inscription of Halikarnassos which records the confiscation and selling of the property of debtors of Apollon, Athena, and Parthenos (SGDI 5727, 5th/4th cent). $B$. comments on some personal and place names. $[\mathrm{AC}]$

25) W. BLÜMEL - H. MALAY, Inscriptions from Aydin Museum, in EA, 21 (1993), p. 129-138 [BE 1995, 517]: Ed. pr. of inscriptions in the Museum of Aydin, including a dedication to Hadrian Soter and Ktistes and Sabina (1), a text mentioning a high priest (6, imp.), and a funerary imprecation

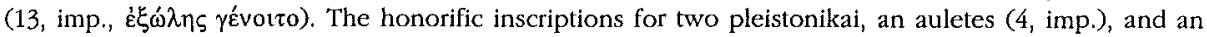
athlete (5, early 3rd cent. AD) mention numerous agons: Sebasteia in Argos, Olympia Komodeia in Sparta, Haleia in Rhodos, Hadriana Olympia in Smyrna, Barbilleia, Ephesia and Hadrianeia in Ephesos, Traianeia in Pergamon, Didymeia Komodeia in Miletos, Pythia in Tralleis, Sebereia Koina Asias in Sardeis, Apollonia Isopythia in Hierapolis, Eusebeia in Puteoli, Sebasta in Neapolis, and Eleusinia in Taras (4), Panathenaia in Athens, Antoneia Severeia in Mantineia, Haleia in Rhodos, Traianeia in Pergamon, Olympia in Ephesos, Olympia and Pythia in Tralleis, Apollonia Isopythia in Hierapolis, and Antoneia Severeia in Kappadokia (5). [AC]

26) M.P. BONZ, Differing Approaches to Religious Benefaction: The Late Third-Century Acquisition of the Sardis Synagogue, in HTR, 86 (1993), p. 139-154: The South Hall of the bathgymnasium complex at Sardeis was possibly constructed as the meeting place of the sacred gerousia, but was taken over by the Jewish community in the late $3 \mathrm{rd}$ cent. AD. B. argues that Sardeis relinquished a major portion of the monumental bath-gymnasium complex to a private religious association in exchange for some measure of financial relief. She explains why the Jewish community and not a pagan religious association assumed possesion of this public space by contrasting the pagan and Jewish approaches to sacred benefaction. While the financing of pagan religious associations relied heavily on a few wealthy patrons and was seriously affected by the economic crisis of the 3rd cent., the Jewish community possessed a flexible and broadly based revenue structure, consisting of both large and small private donations and a well-supported common fund. [AC]

27) J. BOUSQUET - Ph. GAUTHIER, Un juge de Xantbos à Angeira de Pisidie, in REG, 106 (1993), p. 12-23 [BE 1994, 592]: Ed. pr. of an honorific decree of Angeira (Pisidia) for a judge from Xanthos and his secretary (Xanthos, 2nd cent. BC). The Xanthians, the judge, and his secretary are granted prohedria in the athletic contests of Angeira. The honours were to be announced in the agons at Angeira and Xanthos. [AC]

28) J. BOUSQUET - Ph. GAUTHIER, Inscriptions du Létôon de Xanthos, in REG, 107 (1994), p. 319-361 [BE 1995, 555]: 1) Ed. pr. of a decree of Xanthos concerning its sympolity with Myra (after $167 \mathrm{BC}$ ). The dating formula mentions the Xanthian priests of Apollon and Dea Roma as well as a priest $\pi \rho \dot{\text { d }} \pi$ ó $\lambda \varepsilon \omega \varsigma$. This decree is the earliest attestation of the cult of Dea Roma in Lykia; the priest of Dea Roma enjoyed the privilege of being one of the epoymous officials, but is mentioned after the priest of Apollon. It is not clear whether he served for one year or longer. G. argues convincingly that the priesthoood pro poleos was held from 206/5 on by the members of the same family. The sympolity treaty was to be inscribed in the temple of Leto in Xanthos and the temple of Artemis in Myra. This implies that Artemis was the principal deity of Myra and sheds new light on

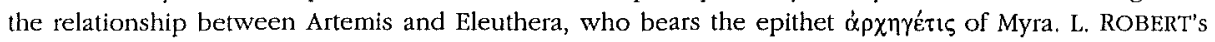
view that Artemis and Eleuthera were two distinct goddesses has to be reconsidered lon the identification of Artemis with Eleuthera $c f$. infra $\mathrm{n}^{\circ}$ 97]. 2) Ed. pr. of two epidosis-lists (second half of the 2nd cent. $\mathrm{BC}$ ) concerning repairs in the temple of Leto and contributions for the gilding of the statues of Apollon, Artemis, Leto, and Parthenon. B. argues that Parthenon is related either to the cult of Elijâna, mentioned in the trilingual inscription of Xanthos (ca. $350 \mathrm{BC}$ ) or to the cult of the Nymphs. The Nymphs are mentioned twice in unpublished Hell. inscriptions; one of them is a dedication addressed to Leto, Apollon, Artemis, and the Nymphs. [ES]

29) A. BRUGNONE, Epigrafia greca, in Kokalos, 39/40 (1993/94), p. 487-514: Review of the recent epigraphic research in Sicily with ample bibliography, among other things about inscriptions of religious interest (the cult of Гevétopes in Nakone, the financial administration of sanctuaries, dedications, Orphic texts, defixiones) [cf. N. CusumaNo, Storia delle religione, in Kokalos, 39/40 (1993/94), p. 623-651]. [AC] 
*30) U. BULTRIGHINI, Divinità della salute nella Creta ellenistica e romana. Ricerche pretiminari, in RCCM, 35 (1993), p. 49-118: This important contribution to the Cretan cults deals particularly with deities which protected health (Asklepios, Eileithyia, the Nymphs), their diffusion, their increasing popularity in Hellenistic and imperial times, and the topography of their sanctuaries. B. presents an impressive dossier of literary, epigraphical, numismatical, and archaeological testimonia for the numerous cities of the island. Besides the prominent Asklepieion at Lebena, whose history, cult, administration, and healing miracles are well documented (p. 81-99), and the Asklepieion of Lisos, which served as the religious center of the koinon of the Oreioi (p. 102-113), sanctuaries of Asklepios existed in the tribal state of the Arkades, in Aptera, Chersonesos, Gortyn, Itanos, Knossos, Lasaia, Olus, Priansos, and probably in Lato and Pyloros. [Another Asklepieion existed in the area of Agiopharango: SEG 42,804; EBGR 1991, 251]. B. locates two other Asklepieia in Larisa, near Hierapytna, following a suggestion made by K.J. RIGSBY (p. 62f, on I.Cret. III, iil 5) Ithe location of this sanctuary in the tribal state of the Arkades is preferable: see A. CHANIOTIS, Die Verträge zwischen kretischen Poleis in der bellenistischen Zeit, Stuttgart, 1996, p. 436-438] and Apollonia (p. 76-79, on I.Cret. IV 182) [see, however, CHANIOTIS, o.c., p. 47: Rhaukos]. Cults of the Nymphs are attested in several areas (Itanos, Lebena, perhaps Polichna). The cult of Eileithyia was prominent in Lato, Inatos, and Amnisos. $[\mathrm{AC}]$

31) A. BuONOPANE, Regio X. Venetia el Histria, in Supplementa Italica. Nuova Serie 11,

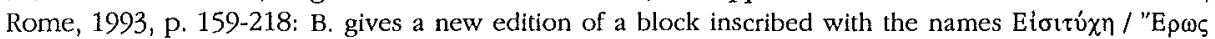
(Mama, 2nd/3rd cent.) [cf. SEG 42, 963]. It is not clear if it is a dedication to Isityche (Isis Tyche) by Eros, or if the text refers to representations of Isis and Eros which stood on the block. [AC]

32) M.D. CAMPANILLE, Osservazioni sul culto provinciale di Augusto in Asia Minore, in Epigraphica, 55 (1993), p. 207-211: C. studies the development of the title used for the high priests of Augustus in Asia from $29 \mathrm{BC}$, when he permitted the erection of the first temples, until the middle

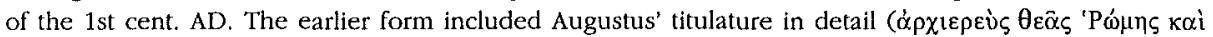

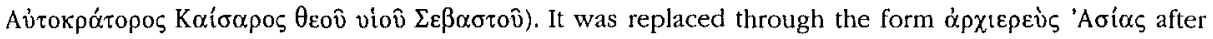
the death of Augustus. [AC]

33) M.D. CAMPANILE, I sacerdoti del Koinon d'Asia (I sec. a.C.-III sec. d.C.), Pisa, 1994: C. offers a complete prosopography of the known archicreis and Asiarchs of Asia and of their families. She discusses in detail the social aspects of these magistracies (social background, family, carreer). On two controversial issues, i.e, whether the titles Asiarch and archiereus designate two different offices and whether women served as high priestesses in their own right, C. very prudently rejects the views expressed by R.A. KEARSLEY [cf. EBGR 1988, 81 and in the same sense infra $\mathrm{n}^{\circ}$ 85] and argues that Asiarchs are identical with high priests and that the high priestesses served in this office only as members of the family of an archiereus and not as separately elected magistrates [cf. EBGR 1992, 96 and 244; infra $\mathrm{n}^{\circ} 205$ ]. [ES]

34) M.D. CAMPANILE, I sommi sacerdoti del Koinón d'Asia: Numero, rango e criteri di elezione, in ZPE, 100 (1994), p. 422-426 [BE 1994, 470]: C. discusses the criteria for the election of the high priests of Asia as well as how they were assigned to the different cities with temples dedicated to the cult of the emperor(s). C. argues that the high priests were not assigned to the cities with a neokoreia according to their own place of origin, but according to the number of votes they received and according to the chronological order in which a city had received the right of a neokoreia. Thus, the candidate with the relative majority of votes was assigned to Pergamon, the first city to receive a neokoreia, the second candidate was assigned to Smyrna, the second city to be awarded a neokoreia and so on. Thus, there were no rank distinctions between the cities of the conventus with the title of neokoros, but only a 'chronological' priority. [ES]

35) G. CAPDEVILle, De la forêt initiatique au bois sacré, in Les bois sacrés, p. 127-143: Through an analysis of basically literary sources $C$. discusses the significance of the forest covered mountain for the rites of passage of the youth in the ancient Mediterranean, particularly in Rome, Crete, and Cyprus. Besides athletic exercises and hunting [cf. infra $\left.\mathrm{n}^{\circ} 110\right]$ the initiation also included the furnishing of the timber necessary for ancient metallurgy. The proximity of foundries, sacred groves, and sanctuaries (e.g., in the sanctuary of Apollon Hylates at Kition and in the Hephaisteion of Athens) should be explained in light of such initiatory practices. In this context C. extrapolates 
from the Cretan epigraphic evidence the importance of Zeus and his sanctuaries (Idaean Cave, Palaikastro) for the initiation of the youth. IOn Cretan initiation rituals see also EBGR 1992, 21. To the Gretan evidence collected by $C$. one should add the finds from the sanctuary of Hermes Kedrites ('Hermes of the Cedar') at Kato Simi, on the Hieron Oros ('Sacred Mountain'). These demonstrate the importance of extra-urban sanctuaries located on the mountains and associated with sacred groves for Cretan rites of passage and confirm the information given by EPHOROS (ap. STRAB., X, 4,

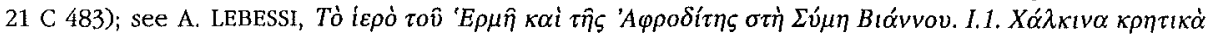

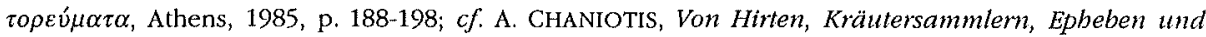
Pilgern: Leben auf den Bergen im antiken Kreta, in Ktéma, 16 (1991), p. 103f. C.'s view that the Idaean Cave was in the territory of Axos, supported only by APOLLONIUS (Arg., I, 1129-1131) is clearly contradicted by the classical and Hell. documentary sources; see more recently A. CHANIOTIS, Habgierige Götter-habgierige Städte: Heiligtumsbesitz und Gebietsansprucb in den kretiscben Staatsverträgen, in Ktèma, 13 (1988) [1992], p. 34f.] [AC]

36) J.-Y. CARREZ-MARATRAY, Une énigme du sphinx: I.Metr. 130, in ZPE, 95 (1993), p. 149152: Discussion, with new readings, of the metrical inscription written on the platform in front of the

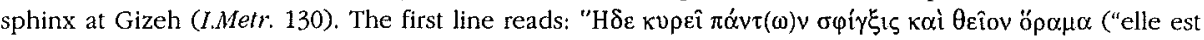

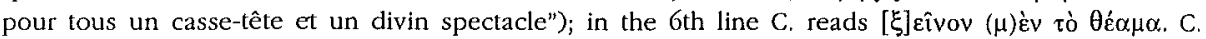

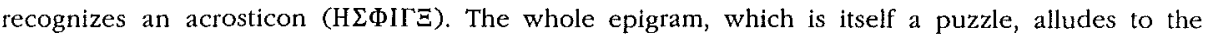
enigmatic nature of the sphinx. $[A C]$

37) A. CHOREMI, in $A D, 44$ Chron. (1989) [1995], p. 18-21: An inscribed base of a statue dedicated

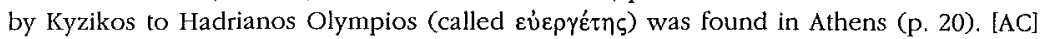

38) A. CHOREMI, in $A D, 45$ Chron. (1990) [1995], p. 16: An honorific inscription for emperor Nero, called Neos Apollon, was found in Athens. [AC]

39) A. CHOREMI, in $A D, 45$ Chron. (1990) [1995], p. 19-22: The boundary stone of a temenos of Asklepios and Hygieia (2nd cent. BC) was found in Athens (p. 21, pl. 14a). [AC]

40) A. Chrysostomou, in $A D, 45$ Chron. (1990) [1995], p. 371-372: A dedication to Artemis Agrotera (Promachi, Almopia, AD 243) [see infra n ${ }^{\circ} 178$ ]. [AC]

41) A. CHRYSOSTOMOU, Ancient Almopia from Prebistoric Times to the Early Byzantine Era, Thessalonike, 1994 (in Greek and English): The cults of the Almopia region in Macedonia (p. 7685) include those of Artemis Agrotera, Dionysos (and his mysteries), Hermes, Poseidon, Sarapis, Zeus Hypsistos, Zeus Meilichios, and the rider god. C. presents an inscription found in 1989 which records a dedication made to Artemis Agrotera from the revenues of her sanctuary (Promachi, AD 242/3) [now published in infra $\mathrm{n}^{\circ}$ 178]. [AC]

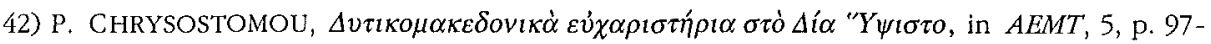
110 [BE 1994, 380]: C. presents the monuments related to the worship of Zeus Hypsistos, a weathergod, in Western Macedonia. Many of these dedications (usually repesentations of eagles) are unpublished. I single out the inscribed dedications from Beroia (p. $99 \mathrm{n}^{\circ} 4$ ), Kyrros (p. $100 \mathrm{n}^{\circ} 1$ ), Anydro (p. 100), and Belbendos (p. 102). The stele from Beroia was dedicated by the 34 members of a cult association. C. also mentions an unpublished dedication to Zeus Kronides from Aiane (p. 101, pl. 10d). The earliest monuments, dating from the Hell. period, were found in Aiane, where the cult probably originated. [AC]

43) G. COLONNA, Doni di Etruschi e di altri barbari occidentali nei santuari panellenici, in Grandi santuari, p. 43-67: C. collects and discusses the archaeological, literary and epigraphic evidence for dedications of non-Greeks, especially Etruscans (Tyrrhenoi), in Delphi and Olympia, focusing on the dedications of Arimnestos in Olympia (PAUS., V, 12, 5) and the dedication (of a lebes?) by the Tyrrenoi in Delphi. C. also mentions an unpublished dedicatory inscription of an Etruscan in the temple of Aphaia in Aigina [ $=$ infra $\mathrm{n}^{\circ}$ 123]. [AC]

44) Th. CORSTEN, Die Inscbriften von Prusa ad Olympum II (IGSK, 40), Bonn, 1993 [BE 1994, 571]: In the second part of the corpus of Prusa [cf. EBGR 1991, 50] C. discusses the topography and the history of the city, the local agons Olympia and Pythia (p. 49), the magistracies (priest of Augustus and sebastophantes, high priest, agonothetes, priest of Zeus Olympios) and the cursus 
honorum (p. 53-61). Numerous cults are attested through inscriptions and coins (p. 69-73: Apollon, Asklepios, Dionysos, Hermes, Hosion kai Dikaion, Kybele, Nemesis, the Thracian rider god, Sarapis and Isis, Zeus Olympios). From the representation of a series of divinities (Aphrodite, Artemis, Athena, Demeter, Dikaiosyne, Eirene, Eros, Hades-Sarapis, Helios, Herakles, Hygieia, Nike, Pan, Poseidon, Roma, Selene, Thanatos, Telesphoros, Tyche) only on coins C. infers that they were worshipped in Prusa (p. 70 note 8: "Da die Prägung von Scheidemünzen im Kleinasien der Kaiserzeit der Hoheit der Städte unterlag, sind die auf den Münzen abgebildeten Götter als Zeichen der städtischen Kulte zu werten") (but see the remarks of J. NOLLE, in EBGR 1992, 161]. The volume also contains the testimonia about Prusa in inscriptions found in other areas (p. 76-82) and inscriptions of unknown provenance in the Museum of Bursa. The latter include many unpublished texts (marked with an asterisk). Korragos, the Attalid governor of Hellespont, is honoured because he contributed sacrificial animals and persuaded a king to return hiera temene to a ciry (1001, early 2 nd cent. BC). Dedications to: Apollon Leonteios (*1017, late Hell.?), Apollon (*1018, 3nd cent. AD: $\theta \varepsilon \hat{\varphi}$

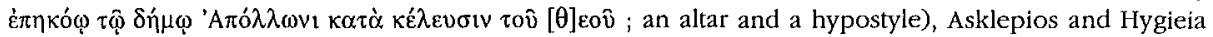
(1019, 2nd cent. AD), Dikaion (*1012, 1st/2nd cent. AD; a temenos), Hermes Meletenos (1020, late

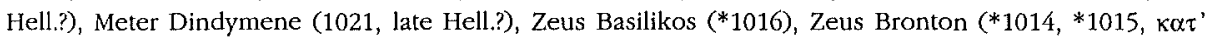

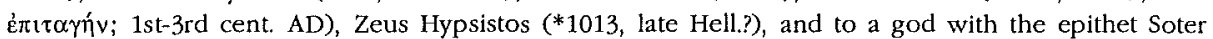
$(* 1023$, imp.); the addressees of two other dedications (*1024 and 1025) are unknown. A dedication

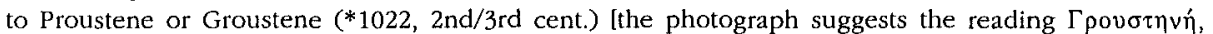

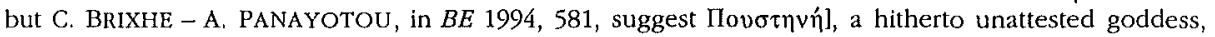

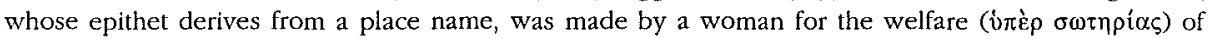
certain persons and for all the Koromanenoi who participated in the worship in her sanctuary (אoi

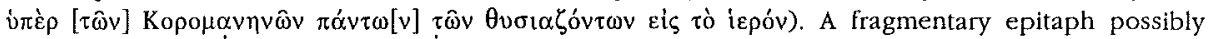
expresses the idea that it is impious (oì óoıv) not to offer the customary burial honours (1027, 2nd cent. AD). [It is more probable that this expression refers to the premature death of the two young men; $c f$. the commentary of $C$. for $* 1030$ with further parallels of the formulaic expression oú $\chi$ ófíc]. A grave epigram for a mystes of Isis $(1028=S E G 28,1585$, late Hell.?) is discussed by R. MERKELBACH. It expresses the idea that the deceased has reached the 'harbour of the blessed' ( $\mu \alpha$ kó $\rho \omega v \delta^{\prime}$ ' $\varepsilon \delta \rho \alpha \mu \mathrm{V}$ Eiç $\lambda_{1 \mu \varepsilon ́ v a \varsigma}$ ). The mystes had performed a ceremony reserved for the initiates, in which a bed covered

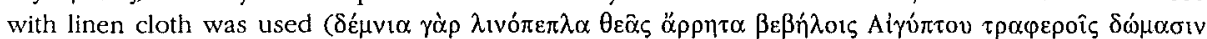

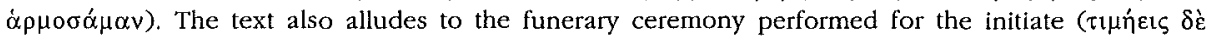

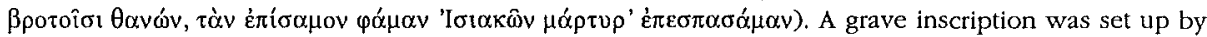

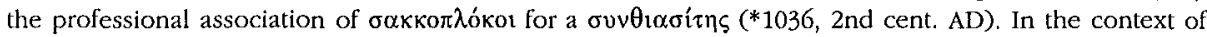

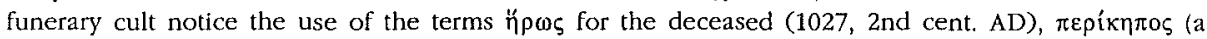

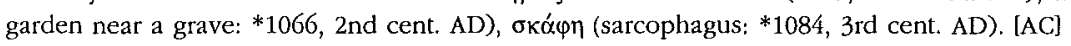

45) F. COSTABILE (ed.), I ninfei di Locri Epizefini. Arcbitettura, culti erotici, sacralità delle acque, Catanzaro, 1991 [SEG 42, 906, 907]: The volume presents an exhaustive study of the sacred caves/nymphaea at Lokroi (Grotta Caruso, Grotta dell'Imperatore), the finds and related objects (terracotta figures and clay models of nymphaea), the cults of the Nymphs and related deities (Aphrodite, Persephone, Demeter, Pan, Dionysos, Zeus, the Dioskouroi, Artemis, Kybele), and the cult of the heroized boxer Euthymos (early 5 th cent.), who was regarded as the son of the river god Kaikinos. C. presents and discusses the partly unpublished clay tablets and herms found in the

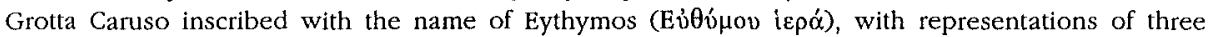
nymphs and a statue of a bull with human face standing before of an altar (4th/3rd cent. BC, p. 195209) [ $f$. EBGR 1988, 5]. C. also mentions an unpublished oxillum inscribed with the name of pan from Centocamera (4th cent. BC; p. 151, fig. 244). C. (p. 105) associates the use of the Grotta Caruso with prenuptial purificatory rituals and with the rite of katabasis prescribed for the nymphai before their wedding in the cathartic lex sacra of Kyrene (LSS 115) [Cf. EBGR 1990, 241). [AC]

46) L. COSTAMAGNA - C. SABBIONE, Una città in Magna Grecia. Locri Epizefiri. Guida archaeologica, Reggio Calabria, 1991: The archaeological guide of Lokroi presents photographs and brief discussion of several epigraphical finds, the financial tablets from the sanctuary of Zeus (p. 38f.) [cf. EBGR 1988, 118], a roof tile with the stamp $\triangle \mathrm{IO \Sigma}$ (p. 85), graffiti-dedications to Kybele (7th/6th cent., p. 106) and Aphrodite (4th cent., p. 107, 112) [cf. supra $\left.\mathrm{n}^{\circ} 16\right]$, and a dedicatory inscription addressed to Zeus (?) Soter (3rd/2nd cent., p. 163). [AC] 
47) N. CUCUZZA, Leto e il cosiddetto Tempio di Rhea di Festos, in Quaderni dell'Istituto di Archeologia della Facoltà di Lettere e Filosofia, Università di Messina, 8 (1993), p. 21-27: C. challenges the attribution to Rhea of a shrine excavated at the southwest corner of the Minoan palace of Phaistos. The archaelogical finds and the evidence for the performance of initiatory rituals in Phaistos (the myth of the metamorphosis of Leukippos from girl to boy; the epigraphic evidence for the festival of the Ekdysia) support an attribution of this shrine to Leto Phytia [on the Ekdysia cf. now D.D. LEITAO, The Perils of Leukippos. Initiatory Transuestism and Male Gender Ideology in the Ekdusia of Phaistos, in ClAnt, 14 (1995), p. 130-163]. A Hell. epigram (I.Cret. I, xxiii 3, 3rd/2nd cent.) concerning the (mystical?) cult of Megale Meter suggests that Leto was associated with Meter Theon. $[\mathrm{AC}]$

48) S. DAKARIS - A.Ph. CHRISTIDIS - J. VOKOTOPOULOU, Les lamelles oraculaires de Dodone et les villes de l'Épire du nord, in L'Illyrie, p. 55-60 [BE 1993, 345]: More than 1,600 fragments of tablets containing questions addressed to Zeus Naios and Dione and oracular responses have been found in the oracle at Dodona; only 65 texts have been published [cf. EBGR 1991, 266]. The questions usually concern problems of everyday-life (family, health, occupation, finances). The authors present 8 texts (two of them already published) containing questions asked by individuals and by communities of Epirus (Apollonia, Bylliones, Epidamnos, Onchesmos, Chaones, Chemara, Orikos,

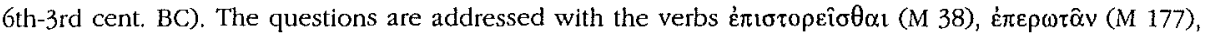
and émıкoเveî $\sigma \alpha_{\alpha 1}$ (M 33). The questions asked by individuals concern the desire for children (M 38), trade (M 4), and dwelling (M 526). Several questions were asked by communities. The Bylliones ( $M$ 827 , ca. 360/340) asked to which god they should sacrifice for the welfare of their property $(\pi \alpha \mu \pi \alpha \sigma i \alpha)$. The question of Onchesmos (M 177, early 4th cent.) may have concerned a shortage of food. The Chaones ( $M$ 22, ca. 340/30, published) asked whether they should relocate a temple of Athena Polias. The Chemarioi ( $M 718$, 4 th cent.) were concerned about their settlement. The enquiry of Korkyra and Orikos (M 33, ca. 350-325, published) concerned the gods or heroes to whom they should sacrifice in order to safeguard welfare, security, and fertility. [AC]

49) G.B. D'ALESSIO, Nota alla tavoletta plumbea di Phalasarna, in ZPE, 97 (1993), p. 290

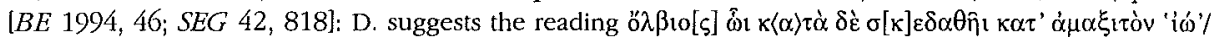

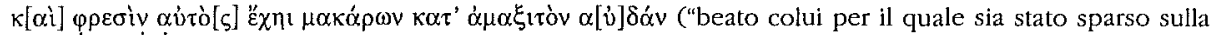
via carraia il grido 'io' ed abbia egli stesso nel cuore sulla via carraia dei beati la voce...") on the lead tablet with a magical poem from Phalasarna (Crete, 4th/3rd cent.) [cf. EBGR 1992, 112]. Thus the word $\varphi \rho \varepsilon \sigma \sigma i \lambda v \tau o \varsigma$ should be erased from LSJ. IOn the lead tablet of Phalasarna cf, infra $\mathrm{n}^{\circ} 156$ and W.D. FURLEY, $Z u$ Form und Funktion von EMSILAI in der griechischen Zaubermedizin, in G.W. MOST - H. PETERSMANN - A.M. RITTER (eds), Pbilanthropeia kai eusebeia. Festschrift fiur Albrecht Dible zum 70. Geburtstag, Göttingen, 1993, p. 80-104]. [AC]

50) R.W. DANIEL, Ein magisches Bleitäfelchen, in ZPE, 100 (1994), p. $337-338$ [BE 1995, 114]: Ed. pr. of a lead curse tablet (now in a private collection in Cologne, 2nd/4th cent. AD) against a

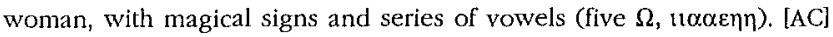

*51) R.W. DANIEL - F. MALTOMINI, Supplementum Magicum. Vol. I (Papyrologica Coloniensia, 16.1), Opladen, 1990: The first volume of the supplement to PMG contains 1 Latin and 50 Greek texts of Egyptian provenance, all published previously. The eds. provide translation and commentaries. 19 texts are pagan protective charms (3rd-4th cent.), usually written on papyrus; the only exceptions are a silver amulet against fever $(2,3 \mathrm{rd}$ cent.) and a stone falcon amulet $(6)$. These objects aimed at protecting their owner in general $(6,7,15)$ or in particular, from evil spirits (13), from the sting of the scorpion $(16,17)$, and from various diseases, i.e., from the inflammation of the

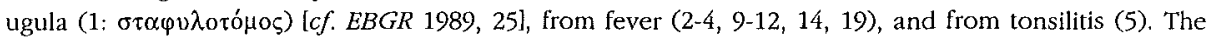
Christian protective charms on papyrus (20-36, 4th-6th cent.) concern themselves also primarily with healing (20-23, 25, 26, 28-35). 15 erotic charms (2nd-4th cent.) were written on lead tablets (37-39, 41, $42,46-50)$, on linen (44), on papyrus (40,43,45), and on a clay vessel (51). Several erotic charms (4651) follow closely the formulary of PMG IV 335-433; three of them (49-51) were written by the same hand. $[\mathrm{AC}]$ 
*52) R.W. D ANIEL - F. MALTOMINI, Supplementum Magicum. Vol. II (Papyrologica Coloniensia, 16.2), Opladen, 1992: The second volume of Suppl. Mag. conains 48 texts, all previously published, with translation and commentary. Seven texts (52-58, 1st-5th cent.) are pagan curses, witten on lead $(53-55,57)$, on a wooden tablet $(52)$, and on papyrus (56). These curses demonstrate a variety of causes: neglection of burial (52), agonistic rivalries (53), the conflict of a master with his slave (56?), and perhaps a legal conflict $(54=D T 38)$; two texts are 'wrath-restrainers' $(57,58)$. Four Christian curses (59-62, 6th cent) aim at the punishment of persons; two of them (59-60) are the wellknown curses of the Christian Sabinos, who cursed his daughter and her husband. Sabinos had himself buried with one of the curses (59), while the hexameters on the other curse were to be inscribed on his gravestone (60). The volume includes also two charitesia (charms to win favour) written on papyrus (63-64, 2nd-3rd cent), two divinatory charms written on a terracotta sherd (65, $3 \mathrm{rd}$ cent.) and on a lead tablet $(66,3 \mathrm{rd} / 4$ th cent.), three charms of uncertain nature written on ostraca $(67,68)$ and on papyrus $(69)$, and 31 formularies $(70-100$, 2nd cent. BC-5th cent. AD). The formularies contain erotic charms $(71-73,82,83$ ?), spells designated to separate a man from a woman (95), to secure favour (97), or to call in customers (97), protective charms (84), charms dealing with a variety of diseases (headache, fever, insomnia, sciatica, etc.: 72, 74, 78, 79, 82, 88, 92, 94, 96, 99), charms against scorpion sting (89), spells for the successful operation of a workshop (99), Homeric oracles (77), instructions for the making of an amulet (80, 81), charms inducing prophetic dreams (85, 90), spells for the identification of a thief (86), and a lamp divination (93). Several formularies $(76,79,82)$ contain short prescriptions for various purposes, e.g., for the relaxation of an erect penis, for picking someone up at the baths, for amorous dalliance with a woman, for frequent sexual intercours, for causing a fight at a banquet, and for turning wine sour (76, cf. PMG VII 167-185), for promoting conception, for inducing a prophetic dream, for restraining wrath, for wining a trial, for curing fever (79). One text contains a prose hymn to the great god (87). Three texts $(96-98,5$ th/6th cent.) orignate in the same magical workshop and suggest mass production. Detailed indices of personal and place names, names of gods, daemons, angels, etc., of Greek, Latin, and magical words, and of vowel combinations, make the two volumes of the Suppl. Mag. an indispensible instrument of work. [AC]

53) J.-C. DECOURT, A propos de quelques inscriptions lyonnaises, in RPb, 67 (1993), p. 237-

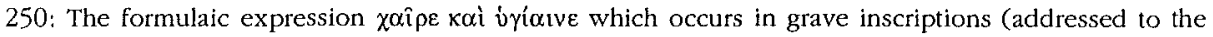
passers-by) should not be taken as an indication that the deceased was the follower of an Oriental salvation cult or a Christian. It is a widespread expression of greeting which says nothing about the religious beliefs of the person buried in the tomb. [AC]

54) J. DE LA GENIÈRE, L'inizio della romanizzazione a Claros, in Grandi santuari, p. 69-79: Recent excavations in the sanctuary of Apollon at Klaros have revealed building activities in the last quarter of the 2 nd cent. BC, including the construction of a new altar for Apollon. G. reports (p. 78) the discovery of a decree of the Ionian Koinon ( $3 \mathrm{rd}$ cent. $\mathrm{BC}$ ) which relates to the reorganization of the pentaeteric festival (sacrifices and agon) at Klaros. [AC]

55) N. DESHOURS, La légende et le culte de Messène ou comment forger l'identité d'une cité, in $R E G, 106$ (1993), p. 39-60: D. discusses the literary, epigraphic, and numismatic evidence for the cult of Messene, the eponymous heroine of Messene and legendary founder of the mysteries of Andania, the contribution of her myths to the construction of the Messenian identity, and her association with Asklepios. The cult must be older than the foundation of Messene in 370/69. [On her temple in the Asklepieion of Messene see now P. THEMELIS, in PAAH, 1987, p. 85f.]. [AC]

56) H. DEVIJVER, The Inscriptions of the Neon-Library of Roman Sagalassos, in M. WAELKENS - J. POBLOME (eds), Sagalassos II, Report on the Third Excavation Campaign of 1992, Leuven, 1993, p. 107-123: Ed. pr. of seven honorific inscriptions for the members of a prominent family of Sagalassos, found in 1992 in the walls of the library (ca. AD 120) [cf. M. WAELKENS - L. BAERT-HOFMAN, The 1992 Excavation Season at Sagalassos, in XV. Kazi Sonuglari Toplantisi, Ankara 24-28 mayir 1993, Ankara, 1994, vol. II, p. 373-407]. T. Flavius Neon (3) served as

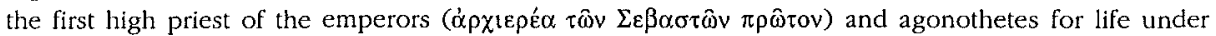

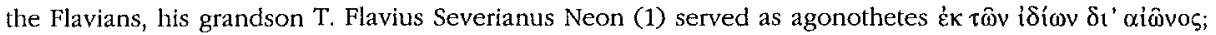

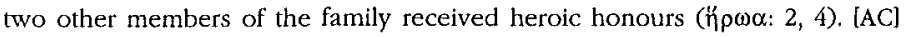


57) M.W. DICKIE, An Epitaph from Stratonikeia in Caria, in $Z P E, 100$ (1994), p. 109-118: In an analysis of the grave epigram for a youth from Stratonikeia [SEG 38, 1103; $E B G R$ 1988, 181] D. discusses in detail the motif of $\beta \alpha \sigma^{\sigma} \sigma \alpha \gamma \nu \varsigma \varsigma$ $\delta \alpha i \mu \omega v$. This text attests the image of Hades' causing his own eyes to waste away out of envy at the beauty of the young man. [AC]

58) M.W. DICKIE, The Identity of Philinna in the Pbilinna Papyrus (PGM ${ }^{2} X X .15$; $S H$ 900.15), in $Z P E, 100$ (1994), p. 119-122: D. argues convincingly that Philinna, the Thessalian woman to whom a spell contained in the Philinna Papyrus is ascribed, should be identified with one of the wifes of Philip II of Macedonia and mother of Philip IV Arridaios. [AC]

59) M.P.J. DILLON, The Didactic Nature of the Epidaurian lamata, in ZPE, 101 (1994), p. 239260 [SEG 42, 293]: In this thorough study of the healing miracles recorded in Epidauros D. exploits the inscriptions to offer a full picture of the ritual practices involved in the Asklepieion (abstinence, ritual bathing, payment of a fee, sacrifice, incubation, demonstration of faith, healing, thanksgiving). The iamata should be interpreted as aretalogies, intended to demonstrate the power of the god. D. also offers a provisional text of healing miracle $n^{\circ} 47$, with a critical apparatus by R. MERKELBACH. [ES]

60) C. DOBIAS-LALOU, Les dépenses engagées par les démiurges de Cyrène pour les cultes, in $R E G, 106$ (1993), p. 24-38 [BE 1994, 73, 701]: D. discusses the accounts of the demiourgoi in Kyrene which record expenses for certain cults (SEG 9, 13 l. 10-21, ca. 335 BC) [cf. EBGR 1988, 29] and presents a new document of this genre. D. observes that these accounts follow the same pattern: a

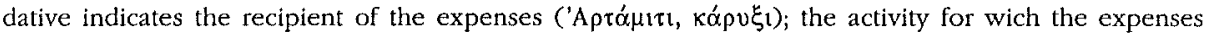
were made is expressed with an accusative ( $\tau \rho \circ \varphi \hat{\alpha})$ ), a genitive of cause $(\tau \rho \circ \varphi \hat{\alpha} \varsigma)$ ), or a prepositional

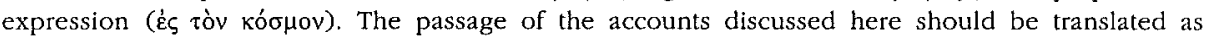
follows: "à l'ourse, pour les cérémonies en l'honneur d'Artémis Katagôgis; à la prêtresse d'Athèna,

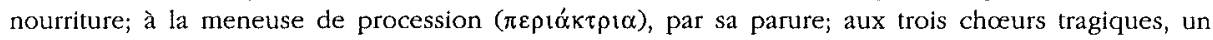
bouf chacun, au chœur dithyrambique, un bœuf, aux chefs de chœurs; aux trois hérauts pour leurs vêtements et leur nourriture (or possibly "aux chefs de chœurs et aux trois hêrauts); aux joueur d'aulos, au secrétaire, au trésorier, au sacrificateur, aux gardes; éclairage aux torches ( $\lambda v \chi v 0 \kappa \alpha t i \alpha)$ en l'honneur d'Iatros à l'approche du soir; les cuisses de chaque bouf atteignant treize statères par bête." The accounts show that the demiourgoi, who administered the revenues of the sanctuary of Apollon, were also resoponsible for expenses for other gods, i.e., Artemis, Athena, Dionysos, and Iatros. The 'bear' is a priestess also mentioned in the cathartic law of Kyrene (LSS 115), of which D. gives a new text and translation ("une femme enceinte, avant d'accoucher, descendra chez Artamis au nymphée (i.e., an area reserved for nymphai) et donnera à l'ourse les pattes, la tête et la peau (de la victime)" [on this text see also $E B G R$ 1990, 241]. D. presents the evidence for the cult of Athena in Kyrene. The term $\pi \varepsilon \rho l o ̛ ́ k \tau \rho \iota \alpha$ does not designate a device for changing the stage-design, but is the title of a woman responsible for a procession. The exact nature and place of the performances of tragic choruses is not known. Iatros is a well known healing deity of Kyrene, identified with Asklepios by PAUSANIAS (II, 26, 9), but also known from the epigraphic evidence as an autonomous deity; thus Iatros should not be interpreted simply as an epiklesis of Asklepios, but as an hypostasis of this god. [AC]

61) F.K. DÖRNER, Epigraphische Forschungen in Kommagene, in Erforschung Kleinasiens, p. 49-58: The history of the discovery of and the research on the cult reforms of Antiochos of Kommagene. [AC]

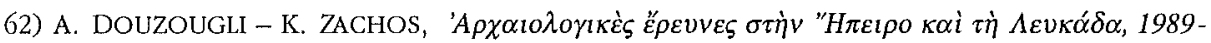
1990, in Epeirotika Chronika, 31 (1994), p. 11-50: Presentation of two honorific inscriptions for two victors of the stadion race (in the age-class of paides); the first boy was winner at the Great Aktia, the second at an agon in Larisa $\left[=\right.$ infra $\left.\mathrm{n}^{\circ} 276\right]$. The texts were probably found in the gymnasium of Nikopolis (imp., p. $43 \mathrm{n}^{\circ} 11$ ). [AC]

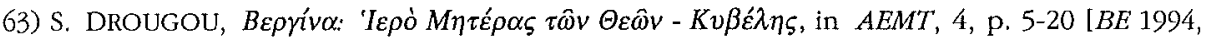
393]: A sanctuary excavated in Vergina could be identified as a shrine of Meter Theon / Kybele (4th-

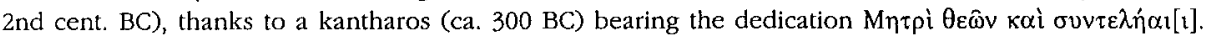
The word $\sigma v v \tau \varepsilon \dot{\lambda} \lambda \varepsilon \dot{\alpha}$ probably designates a cult association. [AC] 
64) M. EGETMEYER, Wörterbuch zu den Inschriften im kyprischen Syllabar (Kadmos, Suppl. 3), Berlin-New York, 1992: This invaluable lexicon of the words and names attested in the inscriptions of the Cypriote syllabary can be used by scholars who have not been initiated into the secrets of the early Cypriote script and language with the help of a Greek alphabetical index (p. 273301), which, however, does not contain every word and name. I single out the names and epithets of gods and the month names I was able to locate in the syllabic part of the lexicon. Divine names and epithets: Aphrodite (a-po-ro-ti-ta-i; Anassa: wa-na-sa-se; Golgia: ko-lo-ki-a; Mychoia: mu-ko-i-a?; Paphia: pa-pi-a), Apollon (a-po-lo-ni; Amyklaios: a-mu-ko-lo-i; Daphnephoros: ta-u-ka-na-po-ri-o; Heleitas: e-le-i-ta-i, i.e., év ě̉ $e ı ;$ Hylatas: u-la-ta-i; Megistos: me-ko-to, Tamasios: ta-ma-si-o), Artemis (a-ra-te-mi-ti; Agrotera: a-ko-ro-te-ra), Asklepios (a-sa-ka-la-pi-o-i), Athena (a-ta-na), Demeter (ta-ma-ti-ri; Wolwea: wo-lo-we-a-i), Dionysos (ti-wo-nu-si-o; Lenaios: le-na-i-yo; Sikytes?: su-ki-ta-i), Hera (e-ra-i), Hermes (e-re-ma-o), Nymphe (nu-pa), Zeus (ti-wo); $c f$. the epithets Amphidexios (a-pi-te-ki-si-o, Herakles or Apollon?) and po-?-e-o-se (Phorieos?). Month names: a-ku-we-u-su-ti-ri-yo (month of Apollon Agyieus), Aphrodisios (a-po-ro-ti-si-yo), a-za-ra-wo-ne [cf. infra $\mathrm{n}^{0}$ 65], Dystros (?, tu-[so-to-rol), Korwewiyo (ko-ro-we-wi-yo), Belchanios (wa-la-ka-ni-o), Megalatheos or Megalantheos (mi-ka-la-te-o), ta-wa-ki-si-yo, and Warmiyon or Warimiyon (wa-ri-mi-yo-ne). [AC]

65) M. EGETMEYER, Zur kyprischen Onomastik, in Kadmos, 32 (1993), p. 19-38: a) The 'Bulwer Tablet' from Cyprus (ICS 327, 6th/5th cent.) [cf. infra $\mathrm{n}^{\circ}$ 170] contains 11 month names. E. discusses the name a-za-ro-wo-ne (*Azarwos), which he associates with the verb $\dot{\alpha} \gamma \varepsilon i$ p $\omega$. It is the only Greek month name deriving from this verb (the etymology of Agrionios is different). [For the notion of 'gathering' in a month name, $c f$. the month Apellaios: see W. BURKERT, Apellai und Apollon, in RbM, 118 (1975), p. 1-21]. b) The name te-na-o-se known from a Cyporiote grafitto in Karnak should be identified with $\mathrm{T}^{\mathrm{h}}$ enàos; it is related to other names composed with the word $\theta \varepsilon$ cós ( $\theta \varepsilon$ - through hyphaeresis), such as Thennos, Themnastos, etc. c) A dedication found in Tala near Paphos [EBGR $1988,110]$ is addressed to a goddess with the epithet wo-lo-we-a-l. E. argues that this epithet does not derive from a place name, but is related to the root *wel- ('wind'). It must be an epithet of Demeter, the goddess of corn ( $c f$. Demeter Himalis, Ompnia, Sito, and Soritis). [AC]

66) N. EHRHARDT, Zwei arcbaische Statuen mit Nympben-Weibungen aus Milet, in EA, 21 (1993), p. 3-8: E. republishes two archaic dedications to the Nymphs in Miletos (C. BLÜMEL, Die archaiscben griechischen Skulpturen der Staatlichen Museen zu Berlin, Berlin, 1964 $4^{2}$, p. $65 \mathrm{n}^{\circ} 71$, who attributed it to Samos; SEG 36, 1056; E. gives new readings) and discusses the evidence for the cult of the Nymphs in archaic Miletos (LSAM 50 1. 29; V. VON GRAEVE, in H. KYRIELEIS, Archaiscbe und klassische griechische Plastik, 1986, I, p. 24f.). [AC]

67) H. EICHNER, Probleme von Vers und Metrum in epichorischer Dichtung Altkleinasiens, in Erforscbung Kleinasiens, p. 97-169: Metrical analysis of the Lykian and Greek version of the epigram of the Lykian ruler Gergis (CGE 177, 5th cent. BC), who set up a stele for the Twelve Gods in the agora of Xanthos, conmemorating his victories. The Greek version may have been influenced by the meter of the Lykian poem (p. 137f.). [AC]

68) K.-L. ELVERS, Der "Eid der Berenike und ibrer Söbne": eine Edition von IG Bulg. III 2, 1731, in Chiron, 24 (1994), p. 241-266 [BE 1995, 433; SEG 42, 661]: E. publishes for the first time the full text of an oath (imitating the formal features of a decree) taken by Berenike and her sons with regard to the safe departure of a suppliant from a sanctuary (Seuthopolis, early 3rd cent. BC). The inscription, discussed in detail by $\mathrm{E}$, is important for two reasons. It presents an interesting case of asylia and describes the guarantee given to the suppliant. It also provides much evidence for the Greek cults in Thrace, attesting for Seuthopolis a sanctuary of $\Phi \omega \sigma \varphi$ ópos (Artemis or Hekate), an altar of Apollon, whose cult had been introduced by the Macedonians, in the agora of Kabyle, an altar of Dionysos (for a priest with a Thracian name see IGBulg. III 2,1732), and a sanctuary of the Great Samothrakian Gods (this is the earliest mention of this cult outside Samothrake). E. discusses the introduction of these cults and the question of the ethnic identity of the cult officials. Elements, such as the existence of sanctuaries with altars in the agora of the city, can be interpreted as a conscious (but perhaps isolated) effort to imitate Greek culture. [ES] 
69) H. EngelmanN, Der Kult des Ares im ioniscben Metropolis, in Erforscbung Kleinasiens, p. 171-176: Coins and inscriptions show that Ares was in addition to Meter the main deity of Metropolis in Ionia. The cult personnel consisted of a priest, a priestess (unusual for his cult), and $\delta$ 'ókovol, who were not slaves but citizens. E. quotes passages of an unpublished Hell. decree, found

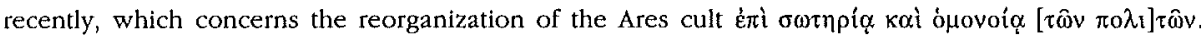
With the support of the banker Hegesias the number of sacrificial animals was increased. This decree was added to an already existing lex sacra about the cult of Ares (i் "

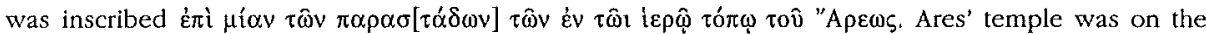
acropolis. In Metropolis, the Greek Ares was probably identified with an old indigenous god, who was worshipped together with female companions ( $c f$. the 'ApEîl in Savatra: IGR III 1481). [AC]

70) H. ENGELMANN, Zum Kaiserkult in Ephesos, in ZPE, 97 (1993), p. 279-289 [BE 1994, 497; SEG 40, 1001]: E. discusses a series of aspects of the imperial cult in Ephesos. a) The location of the Sebasteion of Ephesos has been the subject of a long controversy. E. attempts to solve it by arguing that Ephesos had two Sebasteia. The existence of a Sebasteion within the Artemision may be safely inferred from I.Ephesos 1522; this text belongs to a dossier related to the measurement and registration of the sacred property of Artemis undertaken under the proconsulship of Asinius Gallus (AD 5/6; cf. I.Ephesos 1523-1524); it records the construction of a wall around the Sebasteion. E. suggests the existence of a second Sebasteion in the city by pointing to the importance of Augustus' cult in Ephesos, ( $c f$. the existence of a phyle called Sebaste, of an association of hymnodoi, of the agon Ephesia Sebasta, and of a priest of Augustus). In addition to that, OGIS $458+S E G 4,490$ (letter of the proconsul and decree of the province Asia, $9 \mathrm{BC}$ ) imply the existence of Kaisareia in all the metropoleis of Asia. b) The dedicatory inscription of Apollonios Passalas (I.Ephesos 902) which records the seting up of a statue of Augustus and the dedication of a temenos does not prove the existence of a Sebasteion in the agora ('Stadtsmarkt'). c) A series of inscriptions shows that one of the Augustea of Ephesos possessed a collection of works of art (statues). d) I.Ephesos 412 does not prove P. SCHERRER's view that the altar found west of the Artemision was dedicated to Augustus. e) Two inscriptions (I.Ephesos 1265 and JÖAI 53, 1981/82, p. $142 \mathrm{n}^{\circ}$ 149) show that Artemis was worship-

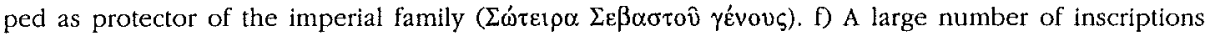
found in and near the agora makes the existence of a gymnasium in this area probable (early hell.early imperial times). [AC]

71) H. FNGELMANN, Zum Opistbodom des Ephesischen Artemisions, in ZPE, 102 (1994), p. 188-190 [BE 1995, 489]: E. gives a new edition and commentary of a fragmentary inscription from Ephesos which refers to a member of the cult personnel of the Artemision (SEG 34, 1100). According to E.'s emendations it is an honorific inscription for an hieros, a person dedicated to Artemis and

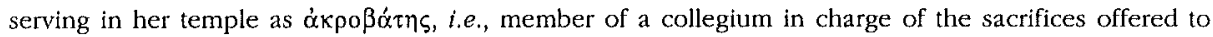

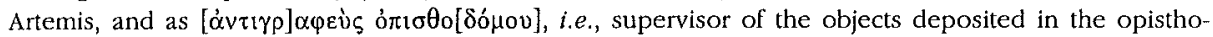
dome. This opisthodome, which is hitherto archaeologically unattested, may have functioned as treasury and/or archive. [ES]

72) H. ENGELMANN - A.B. UNER, Inschriften aus dem Museum von Karaman (Lycaonia), in AnzWien, 129 (1992) [1993], p. 1-24 [EBGR 1992, 65], Addenda: E.-Ö. discuss (p. 8) the

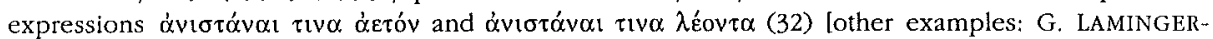
PASCHER, Die kaiserzeitlichen Inschriften Lykaoniens. 1, Wien, 1992, $\mathrm{n}^{\circ} 67=E B G R$ 1992, 126]; they are not related to grades of initiation in the mysteries of Mithras, as suggested by some scholars, but they denote the erection of a grave monument in the form of an eagle or a lion ('to set up for $\mathrm{NN}$ an eagle', 'to set up for $\mathrm{NN}$ a lion'). Also notice that the funerary imprecation $\mathrm{n}^{\circ} 29$ is the same as $\mathrm{n}^{\circ} 150$ in the corpus of LAMINGER-PASCHER (o.c.). [AC]

73) M. ERRINGTON, Inschriften von Euromos, in EA, 21 (1993), p. 15-31 [BE 1995, 521, 523, 524, $525,527,528,529,530$ ]: Ed. pr. of inscriptions found during restoration work in the temple of Zeus Lepsynos at Euromos. Two proxeny decrees (1-2, 4th-3rd cent.) set up in this sanctuary, mention the eponymous priest (1). Among other privileges, the proxenoi received a portion of the sacrificed

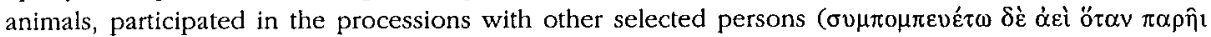

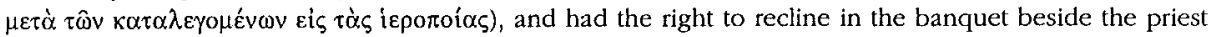
(1 1. 11-19; 2 1. 7-15); the latter honour is very rarely attested Ifor parallels see C. BRIXHE, in BE 1995, 
521]. A benefactor (4, ca. $201 \mathrm{BC}$ ) was honoured with prohedria in the agons and had a privilege

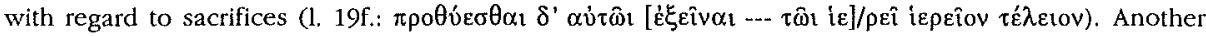
honorific decree, inscribed in the temple of Zeus Lepsynos, mentions the office of the neopoiai ( 7 , late 2nd cent.). A fragmentary decree (5, after ca. 197 BC) concerns the introduction of new magistracies in Euromos (kosmoi, prostatai) probably after the treaty between Antiochos III and Euromos. A priest of Zeus Kretagenes (and Diktynna?) may have served as stephanephoros (for the introduction of Cretan cults in Karia $c f$. C. BRIXHE, in $B E$ 1995, 525]. A boundary stone of a sanctuary (8, 2nd cent.) is inscribed with a metrical lex sacra, prohibiting the entrance to the sacred precinct (Evíiepov, ípòc

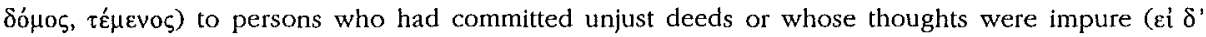

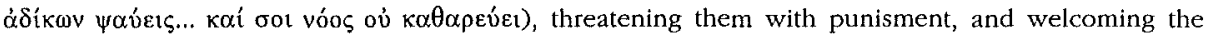

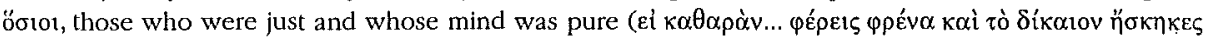

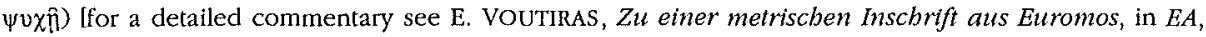
24 (1995), p. 15-19]. The demos dedicated a statue of Kalliteknia of Augustus [i.e., Julia: BRIXHE, ibid.]; her priest was also priest of the Dioskouroi $(9,1$ st cent. BC/AD) [cf. the restoration of BRIXHE, ibid.]. Another dedication is addressed to Zeus Soter (10, 1st cent. AD). [AC]

74) C.A. FARAONE, Notes on Tbree Greek Magical Texts, in ZPE, 100 (1994), p. 81-85 [BE 1995 , 115]: a) The last verse of an erotic defixio [EBGR 1988, 78 ] contains the name of the Nymph Phoebe

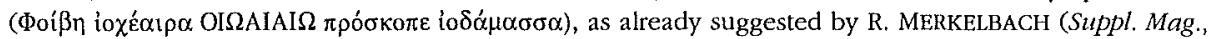
I, p. 204). The imagery of archery in this verse (io $\chi^{\prime} \alpha \iota \rho \alpha$, io $\delta \alpha \alpha \alpha \sigma \sigma \alpha$ ) suggests that Phoebe may have been a poetic name for Artemis. b) $\mathrm{F}$. discusses the $1 \alpha \lambda \delta \alpha$-logos identified by K. PREISENDANZ (PGM I 203-207; IV 1196-99; XIII 971-74) and attested in numerous magical papyri. The $1 \alpha \lambda \delta \alpha-\log 0$ seems to be particularly associated with the sun. The syllable $\varphi \rho t$ is probably the Greek rendition of the name of the sun-god Re; the recent find of a lead disk from Nemea corroborates this interpretation. c) The

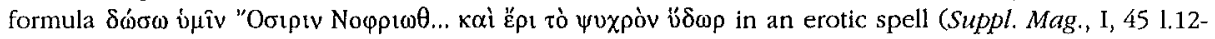
15) is a combination of two common formulas of blessing ("may Osiris be benevolent to you" and "may Osiris draw for you cool water"). [ES]

75) C.A. FARAONE, Molten Wax, Spilt Wine, and Mutilated Animals: Sympatbetic Magic in Near Eastern and Early Greek Oath Ceremonies, in JHS, 113 (1993), p. 60-79: The 'oath of the Theran settlers' (purportedly a text of the 7th cent. BC) quoted in a 4th cent. inscription of Kyrene (MEIGGS-LEWIS, GHI 5) describes an oath ceremony in which wax images are involved. One of the arguments against the authenticity of this text is the claim that the use of wax effigies in magical rituals is unattested in Greece prior to the 4 th cent. and must have been adopted by the Kyreneans long after the foundation of the city. F.'s study demonstrates that the melting of wax effigies and similar rituals of sympathetic magic (spilling wine, mutilating animals) are a commonplace in Near Eastern oaths of the respective period (8th-7th cent.) and were used by the Greeks and Romans [cf. EBGR 1990, 192] in particular situations, when compliance with the oath was believed to be exceptionally difficult for one or both parties; their closest parallels are not the private magic spells of the Hellenistic period. The oath ceremony described in the 'oath of the settlers' corresponds to pactices common in archaic Greece. The evidence (e.g., the similiarity of the expression öpкı $\alpha$, $\varepsilon \dot{\mu v \varepsilon ı v}$ and foedus ferire with analogous Hebrew and Phoenician formulations, the invocation of particular gods as witnesses, and the use of sympathetic curses) suggests that the oath-ceremonies in the Eastern Mediterranean basin had reached some decree of standardization in the archaic period. [AC]

76) F. FERRANDINI TROISI, Una piramidetta iscrita da Canosa, in Epigrapbica, 56 (1994), p. 196-199: Ed, pr. of a ritual prescription written on a pyramidal object made of clay (Canusium,

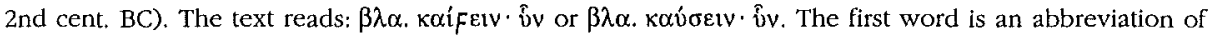
*blamen (= flamen). T. relates this text to the cult of Zeus; the cult of Iupiter pluvialis is attested on a Latin inscription found at the same location. [ES]

77) D. FISHWICK, The Caesareum of Alexandria Again, in AJAH, 12.1 (1987) [1995], p. 62-72; F. reviews the ambiguous literary evidence for the existence of a heroon for Iulius Caesar in Alexandria; he argues that the heroon mentioned by CASsiUS DIO $(51,15,5)$ was dedicated to Divus Iulius (not Marc Antony). The Forum Iulium completed by C. Cornelius Gallus $(A E 1964,255)$ must have been the Caesareum, whose construction started already under Kleopatra. [AC] 
78) B. FORSÉN, The Sanctuary of Zeus Hypsistos and the Assembly Place on the Pnyx, in Hesperia, 62 (1993), p. 507-521 [BE 1994, 312]: F. discusses the sanctuary of Zeus Hypsistos on the Pnyx Hill, which - according to K. KOUROUNIOTIS and H. THOMPSON - was constructed before the 'Third Period of the Assembly Place' (1st cent. AD). F. presents a list of the anatomical votive plaques found in and near the sanctuary (p. 515f.), which were probably originally placed in the niches of the sanctuary; some of them are inscribed (no new texts). The study of the plaques indicates that the earlier dedications were periodically removed from the sanctuary and buried nearby. The floruit of the sanctuary was ca. AD 50-250. The recessed area to the east of the bema is not part of the sanctuary. $[\mathrm{AC}]$

79) J. FOSSUM - B. GLAZER, Seth in the Magical Texts, in ZPE, 100 (1994), p. 86-92: F.-G. discuss the attestastions of the name Seth in the magical / Gnostic literature and suggest that the Egyptian god Seth-Typhon was identified neither with the Jewish Seth, the son of Adam, nor with Jesus. [AC]

80) D.H. FRENCH, Sinopean Notes 4. Cults and Divinities: The Epigrapbic Evidence, in EA, 23 (1994), p. 99-108: F., who prepares an account of the cults and divinities of Sinope in the pre-Roman and Roman periods, presents here a list of epigraphical sources on the subject (no new texts), reproducing only the texts which need emendations. The inscriptions are arranged chronologically. The texts of the 4th-3rd cent. include a dedication to Hestia Prytaneia by the prytaneis (1) and a text which mentions the priesthood of Poseidon Helikonios, a cult well attested in Priene and Miletos. The texts of the 2nd-1st cent. are a dedication to Zeus Dikaiosynos (1) and the funerary inscription of a priestess of Leukothea, whose cult is known from elsewhere in the Mediterranean in the Roman period. More numerous are sources from the imperial period (1st-3rd cent. AD). Dedications to: Asklepios Soter and Hygieia (1), Athena Polias and Soteira (2), Meter Theon $\left(6, \kappa \alpha \tau^{\prime}\right.$ Evंxýv), Theos Herakles (3), Theos Heliosarapis (7), Theos (Megas) Hypsistos (8, three texts), Zeus Helios Sarapis and Isis Myrionymos (9), and Zeus Helios Naul..Jmenos (10). Other cults attested are those of Themis and Helios, Selene, Hermes, Hydrechoos and Seirios (11). Three inscriptions attest the emperor cult (12). Cult officials: a priest of Deus Mercurius (5) and a priestess of Isis (4). F. observes that the deities appearing in the inscriptions of the pre-Roman period are not attested in the imperial period. Hestia Prytaneia and Zeus Dikaiosynos are otherwise unattested in pre-Roman Asia Minor. The cult of Athena Polias and Soteira is attested only in the Roman period, and not in the classical period, as one would expect. The cult of the nymph Sinope, known from the numismatic evidence, is not attested in the epigraphic record. [ES]

81) D.H. FRENCH, The Definition of Territories: Cappadocia, in Cappadoce, p. 49-59: The inscriptions relating to the definition of boundaries in Kappadokia include an unpublished funerary

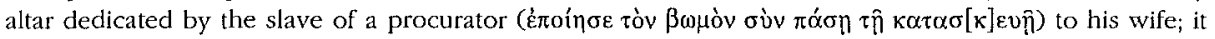
was reused as a boundary marker for the Solotteis (p. 53, 4b1, pl. I). [AC]

82) D.H. FRENCH, Inscriptions from Gerede and Region, in EA, 23 (1994), p. 113-117: Ed. pr. of two altars dedicated to Zeus and to Zeus Epidemios (1st-2nd cent. AD, Gerede $=$ Kretia-Flaviopolis) [for Zeus Epidemios $c f$. infra $\mathrm{n}^{\circ}$ 153]. [ES]

83) D.H. FRENCH, Inscriptions in the Antakya and Gaziantep Museums, in EA, 23 (1994), p. 118-123; 1) Ed. pr. of a square altar dedicated to Theos Megistos Kronos (Zeugma?, 3rd cent. AD); this is the first attestation of the cult of Kronos in Kommagene. 2) Ed. pr. of a miniature altar dedicated to Helios Mithras ( 3 rd cent. AD); this is the first attestation of this cult in the region of Gaziantep (Doliche or Zeugma, rather than Nikopolis or Germanikia). [ES]

*84) E. FRÉZOULS, Les cultes de la Lycie occidentale, in Lykien-Symposion, vol. 1, p. 203-212 [BE 1995, 549]: Survey of the cults in Western Lykia, which comprises ca. 20 cities (among others, Xanthos, Tlos, Arsada, Komba, Nisa, Arykandos, Sidyma, Pinara, Patara, Phellos, Antiphellos, Araxa, Telmessos). Archaeological research has discovered some temples, but only a few could be attributed to specific deities (the Letoon and possibly a temple of Artemis at Xanthos, the Sebasteion of Sidyma). F. mentions an unpublished inscription of Kalyanda (p. 204 note 18) which mentions numerous divinities (Artemis, the Nymphs, Dionysos, Helios, Sarapis, and Demeter). More substantial is the contribution of coins and inscriptions. The deities commonly represented on coins are 
Apollon and Artemis, who were introduced from Greece ( $c f$. their Lykian names Puleni and Ertemi), but not Leto, an originally Anatolian goddess (called Eni mahanani or Eni qlahi ebiyehi). The Lykian inscriptions attest, in addition to these gods, the cults of the Nymphs (Eliyana), the Greek Aphrodite (Pedrite), Zeus, and the local gods Trosobios (Trzzubi), Kakasbos (Herakles), Trqqas, and Malija (Athena). The numerous Greek inscriptions not only attest the emperor cult and the worship of numerous divinities (Agathe Tyche, Aphrodite, Apollon, Ares, Artemis, Asklepios, Athena, Demeter, Dionysos, the Dioskouroi, Hekate, Helios, Hephaistos, Hera, Hermes, Hestia, Isis and Sarapis, Leto, the Nymphs, Pan, Poseidon, and Zeus, and an abundance of local gods, such as Kakasbos, the Kabeiroi, Theoi Loandeis, the Theoi Agroteroi or Agreis, probably identical with the group of the Twelve Gods, and the Patroioi Theoi of Kadyanda, Patara, Pinara, and Xanthos), but they also provide information about sanctuaries, dedications, the motivation behind dedications, the religious feelings of individuals, festivals, cult officials, the protection of graves by gods, theophoric names, and mythology. The divinities most widely worshipped were the triad of the Letoon (Apollon, Artemis, Leto), Helios, and Zeus. [AC]

*85) S.J. FRIESEN, Twice Neokoros. Ephesus, Asia, and the Cult of the Flavian Imperial Family (Religions in the Graeco-Roman World, 116), Köln-Leiden-New York, 1993: F. offers a comprehensive study of the provincial emperor cult in 1st cent. AD Asia. The six chapters are devoted to the early provincial cults in Asia (Pergamon, Smyrna, and Miletos) and the emperor cult in other provinces (p. 7-28), the inscriptions which relate to the temple for the emperor cult in Ephesos (p. 29-49), the development of the word neokoros and the history of the emperor cult in the 1st cent. (p. 50-75), the provincial high priesthoods (p. 76-113), the agons and the festivals connected with the emperor cult (p. 114-141), and the significance of the emperor cult (p. 142-168). F, dates the first neokoreia of Ephesos to the reign of Domitian and the dedication of the temple to AD 89/90. He supports the view expressed by R. KEARSLEY that the provincial high priestesses held this office (from the forties or fifties of the 1st cent. AD) in their own right and not as wives of high priests (p. 81-89). He also agrees that the Asiarchs designate a different office than that of the archiereis (p. 92-112) [cf. EBGR 1988, 81]. The volume also contains lists of the known high priests, high priestesses, and Asiarchs (p. 169-214). IOccasionally, F.'s interpretations are questionable. The trans-

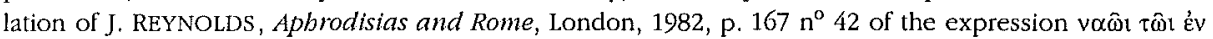

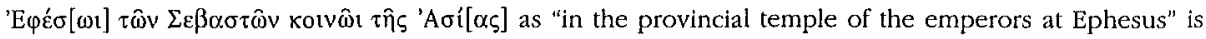
preferable to F.'s "(because of) Asia's common temple etc." (p. 33 and 43). R. KEARSLEY's views concerning the archiereiai and the Asiarchs, which F. follows, have already been disproved with conclusive arguments by recent research; see supra $\mathrm{n}^{\circ} 33$ ]. [AC]

86) C. GallavotT, Revisione di testi epigrafici, in Bolletino dei Classici, 11 (1990), p. 127159: G. restores several archaic metrical inscriptions, including a few dedications, and discusses the metrical structure and dedicatory formulas from the archaic to the imperial period. [AC]

87) $\mathrm{Ph}$. GAUTHIER - M.B. HATZOPOULOS, La loi gymnasiarchique de Beroia, Athens, 1993 [BE 1994, 394]: Ed. pr. of a law (173 lines are preserved) which regulates in detail the function of the gymnasium of Beroia. The oaths quoted in the text and the provisions about the organization of the festival Hermaia are of religious interest. The gods invoked in the oaths of the gymnasiarchos (A 2634) and his co-supervisors (A 55-62) are Zeus, Ge, Helios, Apollon, Herakles, and Hermes. The text also refers to oaths taken by the judges of the competitions at the Hermaia (B 49-51, 54-57). A long passage (B 45-71) describes in detail the festival of Hermaia, on which the editors provide ample commentary (p. 95-117). The festival took place in the last month of the year (Hyperberetaios) and lasted at least two days. The gymnasiarch offered a sacrifice to Hermes and then 'proposed' the prizes to be awarded to the victors of four competitions of young men (probably 18-30 years old):

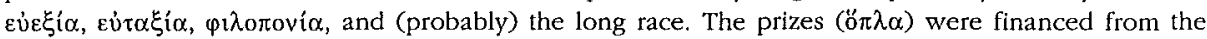
revenues of the gymnasium (B 59-60). The gymnasiarchos nominated seven men, out of which three were chosen by lot to judge the competition of $\varepsilon \dot{v} \varepsilon \xi \hat{i} \alpha$ (cf. B 84-87 on the $\beta p \alpha \beta \varepsilon v \tau \alpha \hat{i}$ ). Under oath the gymnasiarch alone judged the competitions of $\varepsilon \dot{v} \tau \alpha \xi i \alpha$ and $\varphi 1 \lambda o \pi$ oví $\alpha$; the different procedure is explained by the fact that in these two competitions the behavior of the young men throughout the whole year was considered. The gymnasiarchos was also responsible for order and for the punishment of violators. The winners were allowed to wear a wreath on the day of their victory; they were obliged to dedicate their prizes in the gymnasium within 8 months. The paides and the neaniskoi 
competed in the torch-race; the winners probably lit the altar where the final sacrifice took place. One month before the festival (Gorpiaios) the gymnasiarchos appointed three lampadarchai for the neaniskoi and another three for the paides. Each one of them provided the respective age class with olive oil for ten days (B 71-84). The hieropoioi, who were not civic magistrates but were chosen among the young men who attended the gymnasium, received up to two drachmas from every member of the gymnasium in order to offer a banquet (for the neoi); they also appointed their successors. The paidotribai received up to one drachma from each pais and offered a sacrifice on the same day as the hieropoioi (for the paides). They distributed the uncooked meat of the sacrificial animals [for similar sacrifices and competitions off the Koan inscription about the priesthood of Hermes Enagonios (infra $\mathrm{n}^{\circ} 219$ )]. The stealing of objects from the gymnasium was punished as a sacrilege (B 99-101), since the gymnasium was consacrated to Hermes, G.-H. discuss the diffusion of gymnasia in Macedonia and correctly stress the local, Macedonian, character of the training offered in the gymnasium of Beroia, which was dedicated exclusively to the athletic and military education of the youth. $[\mathrm{AC}]$

88) D.J. GEAGAN, Children in Atbenian Dedicatory Monuments, in Boeotia Antiqua IV, p. 163-179 [BE 1995, 243]: The inscribed Athenian dedicatory monuments which name children can be classified into three categories: 1) Dedications to Eleithyia and Asklepios, primarily by women. These dedications reflect the dangers of childbearing and infancy. 2) Dedications mentioning girls who served as kanephopoi in various festivals (Panathenaia, Eleusinia, Epidauria) or in the service of various god (Dionysos and Meter Theon, Zeus Soter and Athena Soteira, Dionysos Lysios, Apollon in the Pythais) and young boys who carried the eiresione in the cult of Apollo. These monuments (with one exception) do not mention the name of the parent/parents who set them up. 3) Dedications naming girls who served as errephoroi in the cult to Athena Polias, girls (kanephoroi), boys (paides pythaistai), and ephebes who participated in the Pythais, and-most common-children who became hearth initiates at the Eleusinia. All of these cult services were very important for the selfrepresentation of the whole family. The projection of status through female as well as male children seems to have been the norm from the classical period down to ca. AD 100. [ES]

89) D. GERGOVA, Common Elements in the Ritual Bebaviour of Thracians and Macedonians, in Ancient Macedonia V, p. 471-478: G. underlines the importance of banquets among the Thracians and the Macedonians as a ceremony bringing together mortals and immortals, and speculates about the religious significance of the Rogozen treasure [cf. EBGR 1989, 40] in the context of "the chthonic-solar Orphic religion" [sic!]. She suggests that the name Kotys is not that of the Thracian king, but that of the Thracian mother goddess ( $c f$. the festival Kotytia) lon the Kotytia

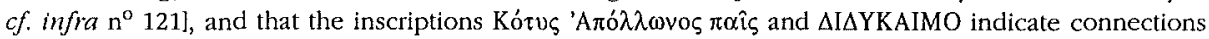
with the cult of Apollon and Zeus Dikaios. [The first inscription clearly shows that Kotys cannot be the name of a mother goddess, the second has nothing to do with Zeus Dikaios]. [AC]

90) M. GIANGIULIO, Le città di Magna Grecia e Olimpia in età arcaica, in Grandi santuari, p. 93-118: Survey of dedications of Greek cities of Sicily and Italy in Olympia and of the participation of their athletes in the Olympic games (6th-5th cent. BC) [cf. H. PHILIPP, Olympia, die Peloponnes und die Westgriechen, in JdI, 109, 1994, p. 77-92]. [AC]

91) M. GIANGIULIO, La dedica ad Eracle di Nicomaco (IG. XIV 652), in A. MAstrocinQue (ed.), Ercole in occidente, Trento, 1993, p. 29-48: Detailed commentary of the metrical dedication of the potter Nikomachos to Herakles (IG XIV $652=$ CEG 396; S. Mauro Forte, territory of Metapontion, late 6th cent. BC) and discussion of the cultural relations between Greek colonists and indigenous population in archaic Lucania. [AC]

92) G. GIANGRANDE, La lamina orfica di Hipponion, in Orfeo, p. 235-248: G. presents a revised text of the Orphic leaf of Hipponion [without knowledge of several recent restorations: see $E B G R$ 1991, 153; 1992, 192, 223; for a new edition see now C. Russo, Dalla morte alla "vera vita": revisione autoptica della lamina di Hipponion, in Epigraphica, 58 (1996), p. 35-50] and discusses a series of problems: a) two verses (2 and 14) are dactylic heptameters; b) the first line (é $\pi \varepsilon \grave{\alpha} \not \alpha \mu \mu \dot{\varepsilon} \lambda \lambda \varepsilon$ $\theta \alpha v \tilde{\varepsilon} \sigma \theta \alpha 1)$ should be translated as "when one is about to die"; c) the change of subject (1.1 and 2) is normal in epic poetry and is not due to a lacuna; d) the adjective $\lambda \varepsilon v$ kó (1. 3), referring to a cypress, does not meen 'white', but 'light green' and indicates a young tree; e) the first line should be read as 


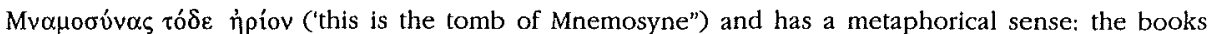
are conceived as the tomb of spoken words ( $f$. THEMIST., Or. 4, $59 \mathrm{D}$ ). In an appendix G. presents the metrical structure of the poem in the light of recent publications (P. SCARPI - D.M. COSI A. TESsIER, I doni di Mnemosyne. Studi sulle laminette orfiche, Firenze 1989; A. BERNABÉ, El poema órfico de Hipponion, in Estudios actuales sobre textos griegos, Madrid, 1992, p. 219f.) (not accessible to us]. $[\mathrm{AC}]$

*93) D. GILL, Greek Cult Tables, New York-London, 1991 [SEG 42, 50, 51, 112, 1677]: $G$. presents a corpus of preserved cult tables ( $\tau \rho \alpha \dot{\alpha} \pi \xi \alpha 1,68$ entries) and discusses in detail their use making ample use of the epigraphic evidence, especially of leges sacrae. The cult tables were used widely for a variety of purposes, e.g., in divination, in theaters, in the grave cult for food offerings to the dead, for the setting out of the crowns of athletes, and for the storage of valuable objects. Their primary use was, however, in sacrifice; they differ from altars both in design and in use. The tables were used for unburned offerings, basically bloodless food offerings, secondarily for the carving of the meat of sacrificed animals. They were also used as dining tables, especially in ritual banquets $(\tau \rho \alpha \pi \varepsilon \zeta \omega \mu \alpha \tau \alpha)$. G. argues that at trapezomata, originally, the god was thought as participating in a common meal with the humans, but later he was thought to be a spectator lon the theoxenia cf. infra $\mathrm{n}^{\circ}$ 121]. The catalogue includes numerous inscribed tables. Some texts were unpublished: a dedication to Demeter, Kore and Zeus Euboulos (27, Naxos, 4th cent. BC), a dedication to Sarapis (40, Athens, 2nd cent. BC), and a table which mentions a festival (Herakleia?) at Diomeia (28, Athens, ca. $400 \mathrm{BC})$; several other unpublished texts are fragmentary $(29,52$, and 60 , Athens). The volume has a list of locations, but no index of divinities. [AC]

94) Z. GOCEVA, Le culte des Cabires et des Nymphes en Asie Mineure et en Thrace, in Eos, 79 (1991) [1992], p. 199-202: G. argues that the cult of the Kabeiroi in Samothrake originates in the Thracian population of Asia Minor and the Aegean islands. In Asia Minor and later in Thrace the Kabeiroi were worshipped together with a triad of Nymphs. [AC]

95) Z. GOCEVA, Die Eigennamen der Stifter auf den Votivtafeln des Thrakiscben Reiters und ibr ethnischer Cbarakter, in L. MROZEWICZ - K. ILSKI (eds), Prosopograpbica, Poznan, 1993, p. 209-215: A cautious study of the names of the worshippers of the Thracian rider god shows that this cult did not loose its Thracian character in imperial times. Even dedicants, who do not have Thracian names, are most likely of Thracian origin. [AC]

96) H.R. GOETTE, Neue attische Felsinscbriften, in Klio, 76 (1994), p. 120-134 [BE 1995, 66]: G. presents a series of inscriptions on rocks in Attika (mainly horos-inscriptions); he also discusses the drawing of an erect phallus found in the 'Temesios-farm' (valley of Agrilliza) and interprets the letter $\mathrm{H}$ beneath the drawing as the beginning of Hermes' name. [AC]

97) Götter, Heroen, Herrscher in Lykien, Wien-München, 1990: The catalogue of an exhibition on Lykia includes three inscribed altars found in Limyra (p. 132f.) dedicated to Artemis Pergaia (22, unpublished) [cf. infra $\mathrm{n}^{\circ}$ 222], Artemis Eleuthera (23), and Artemis Thausike (24, presented by A. DINSTL), and an inscribed dedicatory relief from Myra representing the Twelve Gods of Lykia (p. 134, $\mathrm{n}^{\circ} 26$, presented by K. GSCHWANTLER). [AC]

*98) S. GOLDHILL, Representing Democracy. Women at the Great Dionysia, in Accounts Lewis, p. 347-369: G. discusses the Great Dionysia as a socio-political event and a socio-political institution within the new topography of democracy. The evidence does not allow a firm conclusion about the participation of women. [ES]

99) V. VON GRAEVE, 1991 yili Milet çalismalari, in XIV. Kazi Sonuclari Toplantisi, Ankara 25-29 mayir 1992, Ankara, 1993, vol. II, p. 53-71 [BE 1994, 502]: G. reports the discovery of an archaic deposit in Miletos, containing inscribed sherds of vases dedicated to Aphrodite (p. 56, fig. 89) [cf. infra $\mathrm{n}^{\circ}$ 100]. [AC]

100) V. VON GRAEVE, 1992 Milet Galismalari, in XV. Kazi Sonuclari Toplantisi, Ankara 24 28 mayir 1993, Ankara, 1994, vol. II, p. 83-99: Further inscribed vases dedicated to Aphrodite were found in a late archaic deposit in Miletos (p. 85, 91) [cf. supra $\mathrm{n}^{\circ}$ 99]. [AC] 
*101) F. GRAF, Bois sacrés et oracles en Asie Mineure, in Les bois sacrés, p. 23-29: The evidence of sacred groves in the oracular sanctuaries of Apollon at Didyma, Klaros, and Gryneion shows that they were not always connected with divinities of vegetation. Indeed, they represent the extra-urban space where the human encounters the divine. [AC]

102) GREEK MINISTRY OF CULTURE, An Appeal by the Greek Ministry of Culture, in Sculpture, p. 271-276: Among the objects stolen from the Museum of Tegea in August 1992 were a series of

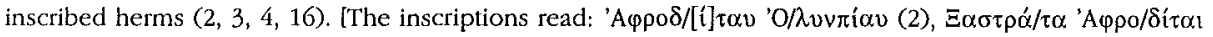

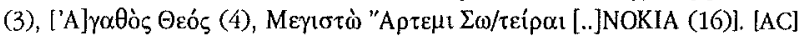

103) Chr. HABICHT, Attische Fluchtafeln aus der Zeit Alexanders des Großen, in ICS, 18 (1993), p. 113-118 [BE 1994, 288; SEG 42, 218]: Three Athenian defixiones from the years before and/or after the death of Alexander the Great are written against prominent Athenian politicians, including Lykourgos, Hypereides, and Kallisthenes [EBGR 1990, 321], officials responsible for the fleet (R. WÜNSCH, Defixionum Tabellae, Berlin, 1897, $\mathrm{n}^{\circ}$ 103), and a group of more than one hundred Athenians, among them Demosthenes $\left(D T \mathrm{n}^{\circ}\right.$ 60). [AC]

104) Chr. HABICHT, Beiträge zur griechischen Prosopograpbie, in ZPE, 101 (1994), p. 219-226

[BE 1995, 208]: 1) Leukaspis, a deity mentioned in the sacrificial calendar of the deme Erchia (LSCG 18), must be a male hero, since Leukaspis is also attested as the personal name of an Athenian citizen [Cf. SEG 34, 1743; 42, 1815]. 2) A recently published inscription from Krannon in Thessaly (SEG 42, 507) $[E B G R$ 1991, 248] is a dedication of the priestess of Artemis to the Charites, whose cult is not well attested in Thessaly. $\mathrm{H}$. identifies the priestess with the victor of a race and dates the inscription to the middle of the 1 st cent. $\mathrm{BC}$, and not to the 4th cent. as proposed by the editor. [ES]

105) Chr. HABICHT, Iasos und Samotbrake in der Mitte des 3. Jabrbunderts v. Chr., in Cbiron, 24 (1994), p. 69-74 [BE 1995, 534]: With the help of a squeeze made by L. ROBERT H. restores an inscription from lasos (I.Iasos 72, mid-3nd cent. BC). It is a proxeny-decree of Samothrake for two Iasians who were sent as theoroi to the festival of the Great Gods in Samothrake, brought an aparche, and sacrificed on behalf of their city. This decree is probably the oldest attestation of the festival of the Great Gods at Samothrake, which must have been established before the middle of the 3rd cent. BC, when Samothrake was still independent. [ES]

106) S. HADJISAVVAS, Olive Oil Production and Divine Protection, in P. ASTRÖM (ed.), Acta Cypria. Acts of an Intemational Congress on Cypriote Archaeology beld in Göteborg on 22 24 August 1991. Part 3, Jonsered 1992, p. 233-249: H. believes that olive oil production on Cyprus was under divine protection on the basis of olive press installations found in sanctuaries or buildings interpreted as shrines (esp. of the Late Bronze Age). He argues that a stone jar dedicated to Apollon Keraiates (Vigla, near Kition; T.B. MITFORD, in $A / A, 65,1961$, p. 116) was either an olive press owned by the sanctuary of Apollon or was offered to the sanctuary by an olive producer. [AC]

107) M.H. HANSEN, Was the Athenian Ekklesia Convened According to the Festival Calendar or the Bouleutic Calendar?, in AJPh, 114 (1993), p. 99-113: The four regular Athenian assemblies per month were convened according to the bouleutic calendar of ten months, not according to the sacred calendar of twelve months. [AC]

108) H. HARRAUER - H. TAEUBER, Inschriften aus Syrien, in Tyche, 8 (1993), p. 31-35 [BE 1994, 628]: Ed. pr, of an alabaster cup from Syria (Hauran?, 2nd/3rd cent.) inscribed with the text: $\chi \hat{n}$

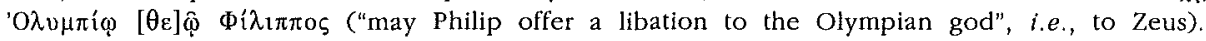
H.-T. offer parallels for the use of the verb $\chi \dot{\varepsilon} \omega$ ('offer a libation'). [AC]

109) D. HARRIS, Freedom of Information and Accountability: The Inventory Lists of the Partbenon, in Accounts Lewis, p. 212-225: H. gives an overview of the accounting principles and the keeping of records in ancient Athens. She argues that the Athenian inventories record only the permanent treasures, for which the treasurers were responsible. They were responsible to Athena, and by extension to the Athenians, but they were also accountable to the Boule. Thus, the Athenian inventories differ from Near Eastern forms of book-keeping. [ES] 
110) M.B. HATZOPOULOS, Cultes et rites de passage en Macédoine (Meletemata, 19), Athens, $1994[B E 1995,303,349,367,405,414,421]$ : In this study H. attempts to reconstruct the initiation rites perfomed by young men and women in Macedonia by studying the epigraphically attested cults and rites. By collecting and analysing a dossier of dedications to Artemis Opooí in

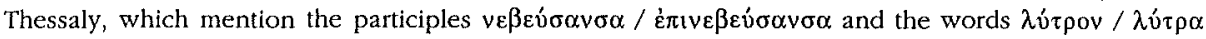

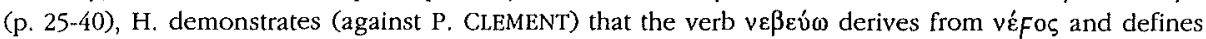
"l'état de quelqu'un qui appartient à une classe d'âge participant à un cycle initiatique". According

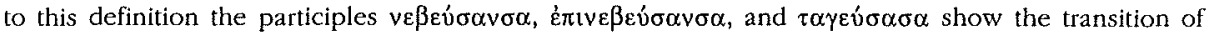
young women from one age-class to the next. Artemis Throsia did not protect pregnant women, but rather protected the end of puberty. Consequently, the dedications addressed to her are to be interpreted as offerings $(\tau \varepsilon \lambda \varepsilon(\hat{i}) o v \mu \alpha)$ or ransom ( $\lambda \dot{v} \tau \rho o v)$ for the successful passing from childhood to the age of a full-grown woman ( $\tau \dot{\varepsilon} \lambda \varepsilon l \alpha$ ). In addition to the cult of Artemis in Thessaly, the same practices can be traced in the cult of Demeter and Kore (or Ko $\lambda \dot{\alpha} \dot{\Theta \varepsilon \alpha}$ ) in Lete, one of the most important cities in Mygdonia (Macedonia, p. 41-53). Using squeezes and notes of Ch. EDSON, H. publishes two inscriptions found in the extra-urban sanctuary of Demeter and Kore during the 1936 excavations (p. 44). They contain the dedication made to Demeter by three women, referred to as $\dot{\alpha} \rho \chi 1 v \varepsilon v 0 \alpha \sigma \alpha \alpha t$

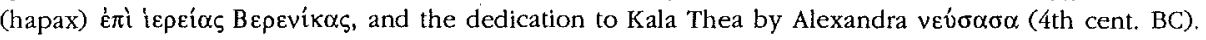

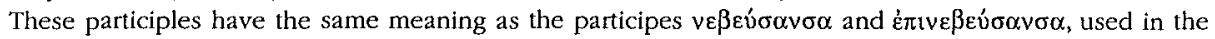
Thessalian dedications. H. also publishes (again from EDSON's notes) two commemorative inscrip-

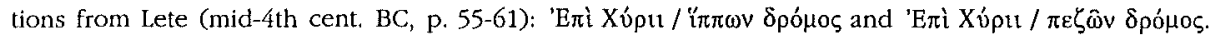
These inscriptions probably belong to a series of inscriptions with identical texts: a) A text from Mandalon [infra $\mathrm{n}^{\circ}$ 178] and another inscription published by $\mathrm{H}$. from Beroia (p. 58, 4th cent. BC):

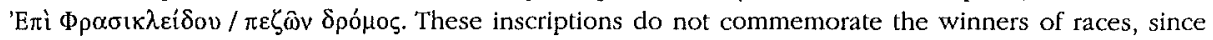
no names are mentioned, but they commemorate the fact that the race took place under the epony-

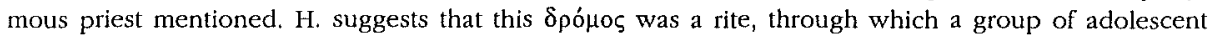
young men or women reached maturity. Similar rites are known from Sparta, Olympia, Athens, Crete and Chios. The ed. pr. of four sacred manumissions from Beroia (AD 248-254, p. 64-72), in which

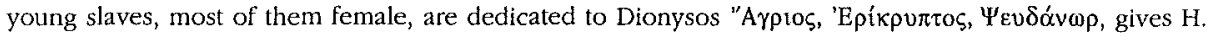
the opportunity to discuss an interesting aspect of Dionysos' cult. The three epithets of Dionysos ("le Sauvage, le Très Caché, le Faux Homme") correspond to the mythological aition of the festival 'A $\gamma$ lóvi $\alpha$, known from different parts of Greece. Dionysos is closely associated with Macedonian rites of passage; his cult may also be linked to that of the Mother of the Gods in Leukopetra. From protectors of the transition of young men and women from one stage of life to the next, Dionysos (as well as Herakles Kynagidas, Meter Theon, Ma, and Artemis) became protector of the transition of slaves to the state of freedom. These texts are dated with reference to the priest of Dionysos

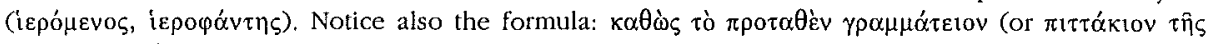
$\delta \omega \rho \varepsilon \hat{\alpha} \zeta) \pi \varepsilon \rho 1 \varepsilon x \chi \varepsilon$. Using notes of A.T.B. WACE and Ch. Avezou and squeezes of Ch. EDSON and J.M.R. CORMACK H. gives a new edition of the letter of Demetrios II to Harpalos (BSA 18, 1911/12, p. 133-139 $\left.n^{\circ} 1\right)$ concerning the priests of Herakles and an inscription of Beroia containing a list of kynegoi (p. 87-111) [supra $\mathrm{n}^{\circ}$ 4]. Both documents attest the relations between the kynegoi and the cult of Herakles Kynagidas, whose priests were selected (by lot) among the kynegoi. $\mathrm{H}$. underlines the role of Herakles and the role of hunting in the training of young Macedonians and, in general, in initiation rituals. He also refers to an unpublished document (from the 37th year of Philip V's reign) which regulates the dress of the kynegoi of Herakles: their cloaks had to be dark ( $\pi \varepsilon \lambda \lambda_{0}$ i) and not

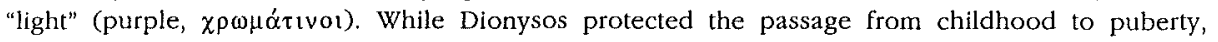
Herakles Kynagidas protected young men in the last stage of their initiation, the passing into the stage of warrior and citizen. [ES]

111) P. HERRMANN, Epigrapbische Forscbungen in Lydien (Polybios aus Sardeis), in Erforschung Kleinasiens, p. 211-219 [BE 1994, 507; 1995, 48, 248]: Ed. pr. of an inscription from Sardeis (middle of 2nd cent. AD). The reverse contains the last part of the minutes of a meeting of the Athenian Areopagos concerning honours awarded to Polybios of Sardeis. In his thanksgiving address Polybios possibly alludes to a mythological tradition about honours awarded to the gods by

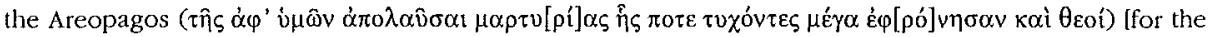
myths, to which the text possibly makes allusion see S. FOLLET, in $B E 1995,248]$. The obverse contains 
the last part of the letter sent by the Panhellenion to Sardeis with regard to Polybios. The letter

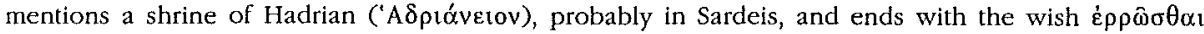

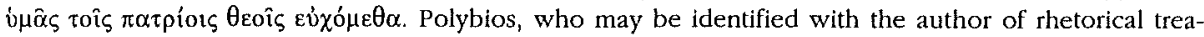
tises and dedicant of a portrait of Cicero in Sardeis, served as Asiarches and probably as representative of Sardeis in the Panhellenion. [AC]

112) P. HERRMANN, Inschriften aus Sardeis, in Chiron, 23 (1993), p. 233-266 [BE 1994, 506]: Ed. pr. of an honorific inscription for C. Asinnius Nikomachos Frugianos, grandson of the high priest of Asia Asinnius Frugi (AD 176). The text gives a further example of the developed titulature of

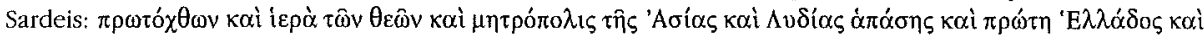

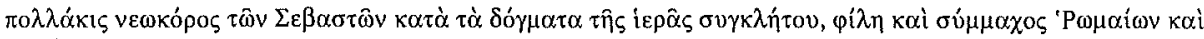

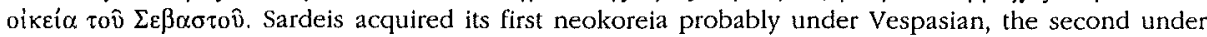
Antoninus Pius, and the third under Elagabalus; the third neokoreia was cancelled under Alexander Severus. The new text, which can be dated to the reign of the latter, uses the unparalled expression

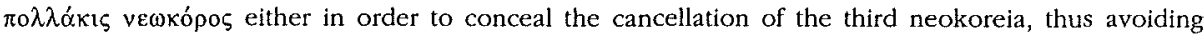
the title 'twice neokoros', or because the degradation had not become final yet. The third neokoreia was restored under Valerianus. [AC]

*113) M.B. HORNUM, Nemesis, the Roman State, and the Games (Religions in the Graeco. Roman World, 117), Leiden-New York-Köln, 1993 [BE 1994, 331]: H. presents an exhaustive catalogue of the literary (p. 91-152) and epigraphic evidence (p. 153-317) for the cult of Nemesis in the Roman world ffor new pieces of evidence from Karallia see EBGR 1990, 53; for Arykanda see infra $\mathrm{n}^{\circ}$ 205; for Kos $c f$. infra $\mathrm{n}^{\circ}$ 219]. The analysis of this evidence supports the conclusion that Nemesis is neither the goddess of the lower classes nor a goddess who protects agons in general. Nemesis' worshippers often belonged to the higher social strata; the numismatic evidence demonstrates the conscious effort of emperors to assert an association of the goddes with the ruler ( $c f$. Nemesis Augusta, p. 15-40). Nemesis was often worshipped as protector of cities (p. 41f.). There is no conclusive evience for an association of Nemesis with agons already in Hellenistic times. On the contrary, Nemesis seems to be related only to the Roman munus and venatio, and not with competitive events in general (p. 43-88). H. also discusses the early evidence for Nemesis' cult in Rhamnous and Smyrna (p. 10-14), her iconography, worship, and epithets (p. 56-78). [AC]

114) G.H.R. HORSLEY, A Bilingual Funerary Monument in кLov $\eta \delta$ óv Form from Dion in Nortbern Greece, in Cbiron, 24 (1994), p. 209-218 [BE 1995, 410]: Ed. pr. of a bilingual inscrip-

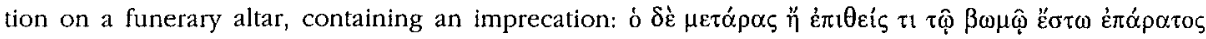
(Dion, 1st/2nd cent. AD). [ES]

115) A. HUSSEIN - G. WAGNER, Une nouvelle dédicace grecque de la Grande Oasis, in $Z P E$, 95 (1993), p. 153-155 [BE 1993, 679]: Ed. pr. of a stele found in the temple at Qasr el Zaiyan in the Great Oasis, dedicated by an hypomnematographos غ̇ $\pi^{\prime} \alpha \gamma \alpha \theta \hat{\omega}$ (3rd cent. AD). [AC]

116) A. HUSSEIN - G.WAGNER, Une dédicace grecque du grand temple d'Esment el Kbarab,

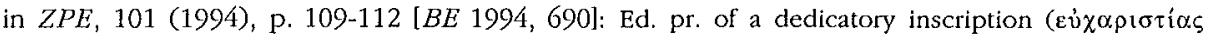

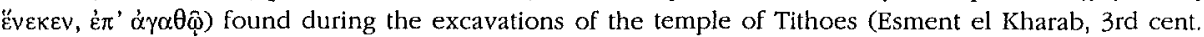
$\mathrm{AD})$. The dedication can be safely assigned to this god, although the name of the deity is not pre-

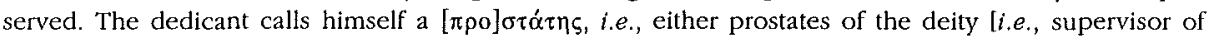
the sanctuary] or president of a cult association devoted to the cult of Tithoes. [ES]

117) G. IACOBACCI, La laminetta aurea di Hipponion: Osservazioni dialettologicbe, in Orfeo, p. 249-264: I. studies the language of the Orphic text of Hipponion (a combination of Ionian, epic elements and Dorian dialectic features) and the relation between this leaf and other Orphic texts. It is possible that the Ionic elements were superimposed on a nucleus originally composed in the Dorian dialect. [AC]

118) B. IPLIKÇIOGLU, Epigraphiscbe Forscbungen im antiken Termessos und seinem Territorium, in Erforscbung Kleinasiens, p. 255-263: The inscriptions presented here have already been published: see B. IPLIKÇIOGLU in Zusammenarbeit mit G. ÇELGIN und A. VEDAT ÇELGIN, Epigraphiscbe Forschungen in Termessos und seinem Territorium I, Wien, 1991 [EBGR 1992, 103]. [AC] 
119) H.P. ISLER, Gerrai. Ein neuer inschriftlicher Beleg aus Sizilien, in ZPE, 101 (1994), p. 103-105: Ed. pr. of an inscribed loom weight (Sicily, early Hell.). The first line names the Charites in the accusative; the word $\gamma$ éppo,t, which designates the male and female genitals, is written on the second line. The last word can be understood as a mocking remark either to the Charites, patrons of the female weavers, or to the users of the loom weight themselves. [ES]

120) M.H. JAmeson, The ritual of the Athena Nike Parapet, in Accounts Lewis, p. 307-324: $\mathrm{J}$. interprets the ritual on the parapet of the temple of Athena Nike as the sacrifice of sphagia which was performed on the battlefield before the beginning of the battle. Nike and Athena guaranteed the success of the Athenian people. Through the violent act of $\sigma \varphi \alpha$ ó $\zeta \mathrm{v} v$ Nike ensured, under Athena's gaze, the victory of the Athenians. [ES]

*121) M.H. JAMESON - D.R. JORDAN - R.D. KOTANSKY, A Lex Sacra from Selinous (GRBS Monographs, 1), Durham, 1993 [BE 1995, 692]: J.-J.-K. publish with thorough commentary one of the most important recent epigraphic finds, a lead tablet from Selinous (ca. 460/450 BC) containing a lex sacra which concerns purification rituals. All the problems connected with this text cannot be discussed in detail here [cf. the detailed discussion of L. DUBOIS, in BE 1995, 692]. I give the editors' cautious translation: Column A: "[2 lines, traces] ... leaving behind (masc. pl.) ... but let the homo-

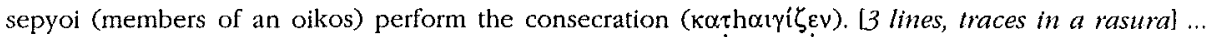
(?) the hiara (images?), the sacrifices (are to be performed) before (the festival of) the Kotytia and (before) the truce, in the fifth year, in which the Olympiad also occurs. To Zeus Eumenes [and] the Eumenides sacrifice a full-grown (sheep), and to Zeus Meilichios in the (plot) of Myskos a fullgrown (sheep). (Sacrifice) to the Tritopatores, the impure (rois $\mu$ topois), as (one sacrifices) to the heroes, having poured a libation of wine down through the roof, and of the ninth parts burn one. Let

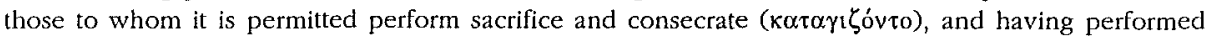
aspersion ( $\pi \varepsilon \rho \rho \alpha \alpha v \alpha \vee \tau \varepsilon \zeta$ ) let them perform the anointing ( $\left.\kappa \alpha \tau \alpha \lambda_{1} v \alpha \dot{\alpha} \nu \tau\right)$, and then let them sacrifice a full-grown (sheep) to the pure (Tritopatores). Pouring down a libation of honey mixture ( $\mu \varepsilon \lambda i$ ikp $\alpha \tau \alpha$ ), (let him set out) both a table and a couch, and let him put on (them) a pure cloth and crowns of olive and honey mixture in new cups and cakes ( $\pi \lambda \alpha \sigma \mu \alpha \tau \alpha)$ and meat; and having made offerings let them burn (them), and let them perform the anointing having put the cups in. Let them perform the ancestral sacrifices as to the gods. To (Zeus) Meilichios in the plot of Euthydamos let them sacrifice a ram. And let it also be possible to sacrifice after a year. Let him take out the public hiera and put out a table before (them), and burn a thigh and the offerings from the table ( $\tau \dot{\alpha} \pi \dot{o} \tau \alpha \hat{\alpha} \varsigma \tau \rho \alpha \varepsilon \varepsilon_{\alpha \varsigma}$ $\dot{\alpha} \pi \dot{\alpha} \rho \gamma \mu \alpha \tau \alpha$ ) and the bones. Let no meat be carried out (of the precinct) ( $\mu \varepsilon \dot{\chi} \chi \varphi \varepsilon \rho \dot{\varepsilon} \tau$ ). Let him invite whomever he wishes. And let it also be possible to sacrifice after a year, at home. Let them slaughter ... statues ... [Let them sacrifice] whatever sacrifice the ancestral customs permit ... in the third year ..."

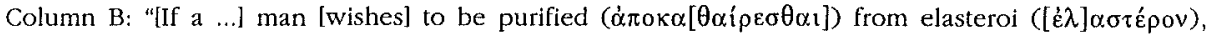
having made a proclamation from wherever he wishes and whenever in the year he wishes and in whatever [month] he wishes and on whatever day he wishes, having made the proclamation whithersoever (i.e., to whatever directions) he wishes, let him purify himself ( $\kappa \alpha \theta \alpha \iota \rho \varepsilon \sigma \theta 0$ ). [And on] receiving (him, i.e., the elasteros), let him give (water) to 'wash with and a meal and salt to this same one, and having sacrificed a piglet to Zeus, let him go out from it, and let him turn around; and let him be addressed, and take food for himself and sleep wherever he wishes. If anyone wishes to purify himself, with respect to a foreign or ancestral one (sc. elasteros), either one that has been

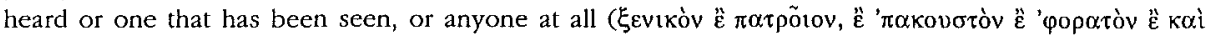

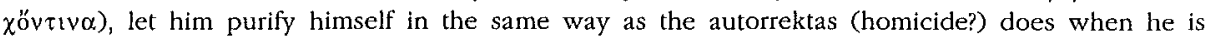
purified of an elasteros. Having sacrificed a full-grown (sheep) on the public altar, let him be pure. Having marked a boundary with salt and having performed aspersion with a golden (vessel), let him go away. Whenever one needs to sacrifice to the elasteros, sacrifice as to the immortals. But let him slaughter (the victim so that the blood flows) into the earth." The text describes rituals for the removal of pollution of an uncertain nature, persumably pollution by death (rather homicide than natural death). This pollution affected not just an individual or a group, but the ancestral spirits (Tritopatores) as well. The procedures in column A show an interaction between the individuals and the gentilician group (hoporénvol) which performed the purificatory rites and the authorities.

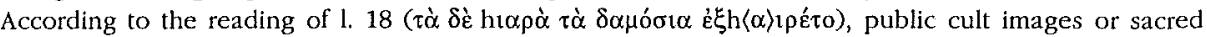

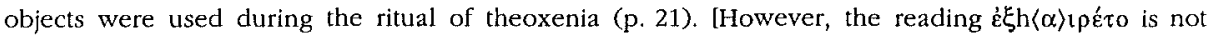


certain, and it is questionable whether the $\delta \eta \mu o ́ \sigma t \alpha$ iøp⿳亠㐅 can be cult images of public sanctuaties; the

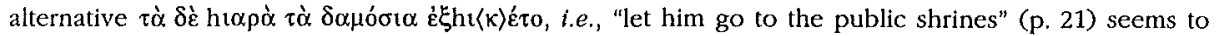
me more attractivel. The rituals had to be completed before two points in the year which marked a ritual renewal of the community, i.e., the festival Kotytia and (every fourth year) the truce of the Olympic festival. The performance of these rites in the following years was optional. The recipients of the sacrifices were deities associated with bloodshed and fertility: Zeus Eumenes (attested only here), the Eumenides, Zeus Meilichios, and the Tritopatores (pure and impure). The purifications in column B were performed under the initiative and were the responsibility of individuals. The purifications concerned themselves with the é $\lambda$ ó $\sigma \tau \varepsilon \rho \circ$, a word which probably designates visitants or hostile spirits (probably, again, in the context of homicide). The closest parallel for the actions prescribed (proclamation, reception, washing with water, a meal, use of salt, sacrifice of Zeus, withdrawing, turning around) is found in the cathartic law of Kyrene (LSS 115 B 28-39) in connection

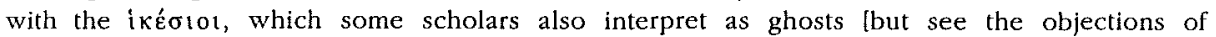
V. KONTORINI $(E B G R 1989,60)$ in the light of a similar lex sacra from Lindos, which are not taken into consideration by the editors]. In their excellent commentary the editors discuss the rituals (sacrifices, theoxenia, libations, purification), the cults of Zeus Eumenes, the Eumenides, Zeus Meilichios (a widely worshipped deity associated with prosperity, bloodshed, and the dead), and the Tritopatores, the festival Kotytia [cf. DuBoIs, o.c.], the meaning of $\dot{\varepsilon} \lambda \dot{\alpha} \sigma \tau \varepsilon \rho \circ \varsigma_{\text {, }}$ and group cults, the Selinountian curse tablets, the sacred area of Zeus Meilichios, and possible Punic influence on the cult of Zeus Meilichios. [AC]

122) A. JÖRDENS - G. BECHT-JÖRDENS, Ein Eberunterkiefer als 'Staatssymbol' des Aitoliscben Bundes (IG XII 2, 15). Politiscbe Identitätssuche im Mytbos nacb dem Ende der spartanischen Hegemonie, in Klio, 76 (1994), p. 172-184 [BE 1995, 104]: The relief above the asylum treaty between the Aitolian Koinon and Mytilene (IG XII 2, 15, late 3rd cent. BC) does not represent a ship, but the jaw bone of a boar. This was the symbol of the Aitolian Koinon and alluded to the hunting of the Kalydonian boar. The 'jaw of the Kalydonian boar' as well as the 'spear of Meleagros', both represented on Aitolian coins, were probably revered as relics; the relevant myths contributed to the collective identity of the Aitolians. [AC]

123) A.W. JOHNSTON, Appendix on the Graffito on $B$ 11, in $A A, 1993$, p. 597-598: $\mathrm{J}$. discusses the Etruscan graffito on a vase dedicated to Aphaia (Aigina, ca. $500 \mathrm{BC}$ ) [cf. infra $\left.\mathrm{n}^{\circ} 270\right]$. $[\mathrm{AC}]$

124) C.P. JONES, The Decree of Ilion in Honor of a King Antiocbus, in GRBS, 34 (1993), p. 73 92 [ $B E$ 1995, 472]: J. attributes the decree of Ilion in honor of a king Antiochos (I.Ilion 32) to Antiochos I and argues for a date between about 278/274 BC lagainst the view of F. PIEJKO: $E B G R$ 1991, 192]. The decree, issued upon the arrival of the king on this side of the Taurus, provides that the priestess, the hieronomoi, and the prytaneis pray to Athena Ilias "that the arrival of the king and his sister the queen, the Friends, and the forces should have been for the best, and that all other good things should come about for the king and the queen, and that the state and their kingdom should last, increasing as they themselves desire." [AC]

125) D.R. JORDAN, Magica Graeca Parvula, in $Z P E, 100$ (1994), p. 321-335 [BE 1995, 113]: 1) A defixio from Aphaka ( $D T$ 15) contains the well attested formula 'destroy the three hundred sixty-five

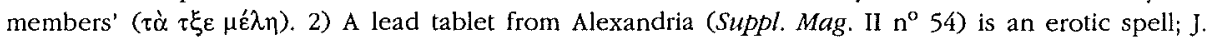
offers a new restoration. 3) Three curse tablets ( $D T \mathrm{n}^{\text {os }} 252$ and 253; EBGR 1990, $\left.147=S E G 40,921\right)$

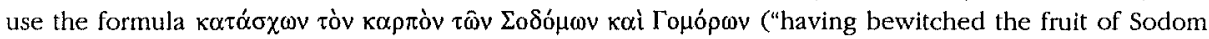
and Gomrrah"). 4) J. provides numerous parallels for a curse on the horses and the charioteers of the Blues $(S E G 7,213)$. [AC]

126) D.R. JORDAN, Inscribed Lead Tablets from the Games in the Sanctuary of Poseidon, in Hesperia, 63 (1994), p. 111-126 [BE 1995, 111]: Ed. pr. of one complete and four fragmentary lead tablets from the sanctuary of Poseidon at Isthmia (imp.). Four texts (1-4) are probably the ballots used by the judges of the Isthmian agon for the admission or disqualification of would-be competitors. Notice the verb ékкp'va ('disqualify'). The fifth text is a defixio against runners, inscribed with magical characters. [ES] 
127) D.R. JORDAN, Inscribed Lamps from a Cult at Corinth in Late Antiquity, in HTR, 87 (1994), p. 223-229: J. republishes, after close examination, the graffiti on Christian lamps discovered in a large underground bath complex in Korinth ('Fountain of the Lamps', 5th/6th cent.). The

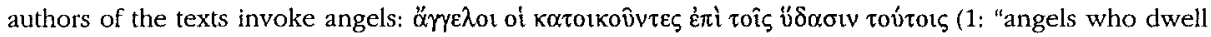

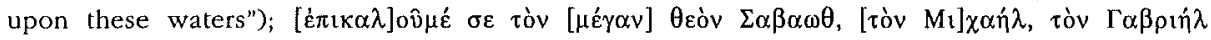
(2: "I invoke you by the great god Sabaoth, by Michael, by Gabriel" or "the (god) of Michael and the (god) of Gabriel" [or "I invoke you, the great god Sabaoth, etc."]. The invocations are followed by

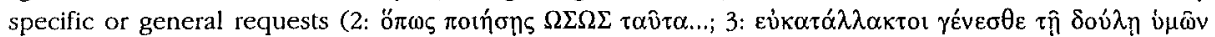

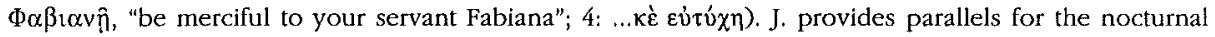
invocation of the supernatural in association with water. The 'Fountain of the Lamps' may have been used for baptisms, but the survival of a pagan healing cult cannot be excluded. [AC]

128) F. KAYSER, Une inscription de Métélis au Musée d'Alexandrie, in ZPE, 97 (1993), p. 213216: Ed. pr. of an honorific inscription set up by the polis Metelis under the supervision of two municipal officials; one them is the high priest of the local imperial cult (3rd cent. AD). [AC]

129) F. KAYSER, Un vétéran au temple de Montou à Tôd (Haute Egypte), in ZPE, 97 (1993), p. 217-220 [BE 1994, 688]: Ed. pr. of a dedication made for the fortune of an emperor by a veteran to Apollon Theos Megistos (=Montou) and the Ktistes (Tod, 2nd cent. AD). The anonymous Ktistes is probably the founder of a shrine. Another (Latin) inscription ( 2 nd/3rd cent.) records building activities in this sanctuary. [AC]

130) F. KAYSER, Nouveau textes grecs du Quadi Hammamat, in ZPE, 98 (1993), p. 111-156: Quadi Hammamat is one of the stations on the route from Koptos to the Red Sea. It has a small fortress, quarries, and a sanctuary of Min-Pan. A series of proskynemata have already been published (I.Ko.Ko. 38-140); another 16 proskynemata were found during recent excavations in part of the temple dedicated to Pan in AD 18 ( $n^{\text {os }} 1-16,1$ st cent. AD). The proskynemata were usually written by soldiers $(1,5,6,9)$ and workers of the quarry $(11,14)$. They are addressed to Pan $(9,10)$ and his

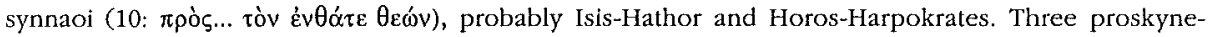
mata are addressed to the 'gods in Persou' $(4,7,15)$; Persou was probably a place near the Paneion.

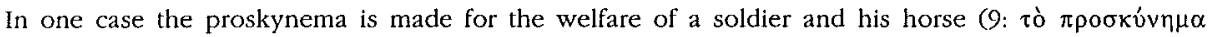

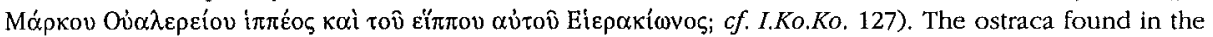
same place $\left(\mathrm{n}^{\mathrm{os}} 20-60\right)$ are not of religious interest. [AC]

131) D. KIENAST, Antonius, Augustus, die Kaiser und Atben, in K. DIETZ - D. HENNIG - H. KALETSCH (eds), Klassiscbes Allertum und frübes Cbristentum. Adolf Lippold zum 65. Geburtstag gewidmet, Würzburg, 1993, p. 191-222: In this excellent general study of the treatment of Athens by Roman statesmen and emperors from Marc Antony to Marcus Aurelius, K. also discusses the divine honours bestowed upon Marc Antony, who was worshipped as Neos Dionysos and was honoured in the Panhellenic festival Antonieia Panathenaia (38 BC). Augustus continued to treat Athens well after his initiation into the Eleusinian mysteries (19 BC); under his reign the client kings decided to complete the building of the Olympieion and to dedicate this temple to the Genius Augusti; C. Caesar was worshipped as Neos Ares. The promotion of Athens reached its colophon under Hadrian, who was also initiated into the mysteries of Eleusis. In addition to his extensive building program and the restoration of festivals, Hadrian introduced the worship of Antinoos and founded the Panhellenion, dedicated to his cult (Hadrianos Panhellenios). K. suspects that Hadrian's foundation of the Panhellenion and his cult as a synnaos of Athena in the Parthenon may have been modeled after Marc Antony's measures (especially, the celebration of Antonieia Panathenaia as a Panhellenic festival). [AC]

132) D. KNIBBE - H. ENGELMANN - B. IPLIKÇIOGLU, Neue Inscbriften aus Ephesos XII, in $J O ̈ A I, 62$ (1993), p. 113-150 [BE 1994, 78, 99]: Ed. pr. of 79 inscriptions found in Ephesos in 19871990 , some of which are of religious interest. Cult associations: An honorific inscription for a benefactor of an association (koinon, synodos) of Aphrodisiastai (17, 2nd cent. BC) informs about its organization: The association had magistrates (oikonomos, scribe), possessed a shrine (klision), and celebrated teletai. It was dedicated to the cult of Aphrodite Polyainetos and perhaps another male deity, as can be inferred from the provision that the benefactor would be crowned with the crown of

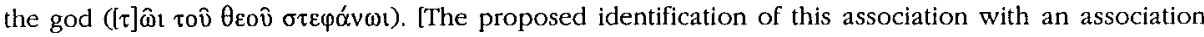


of Rhodian tradesmen is improbable, since the text is not written in the Dorian dialect]. Another honorific inscription was set up by a thiasos (39, Hell.). Priests: An honorific inscription for a priestess of Artemis and prytanis (21) records her services: she performed the sacrifices, distributed the sacrificial meat to the boule, the gerousia, the personnel of the sanctuary (hieros oikos) and the hieronikai of the Artemisia. According to another honorific inscription M. Aurelius Papio, priest of

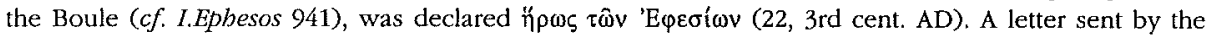
proconsul P. Petronius (9, AD 30/31) attests a priest of Claudius, probably for the civic and not the provincial cult of the emperor. A chrysophoros, the son of a naopoies, expresses his thanks to

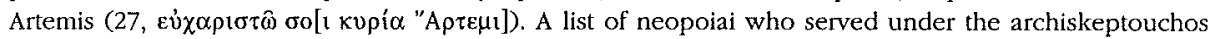

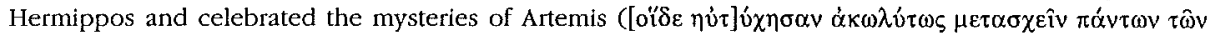

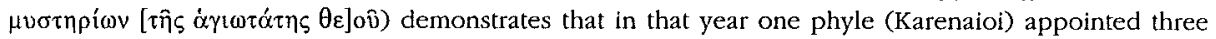
neopoiai (not two, as usually). The same list also names the hieros Theopompos, who served as spondopoios for several years (33, ca. AD 160). Also notice a priestess $\pi$ pò $\pi$ ó $\lambda \varepsilon \omega \varsigma$ (29) and an hierokeryx (69). Dedications: to Artemis Ephesia and Hadrian (12, it records the construction of dikes in the river Manthites), Artemis Ephesia and Domitian (15), Artemis Ephesia (78), Sarapis and Isis (28, Hell.?); an altar of Apollon Prostaterios (26). Sanctuaries: An honorific inscription for M. Messala Corvinus, benefactor of the sanctuary of Artemis and the city (18); the boundary stone of the sanctuary of a chiliastys (30, Hell). Festivals: A series of letters of emperors and governors concerning the privileges of the gerousia illuminate a provision in the endowment of Vibius Salutaris [EBGR 1991, 206]: should his heirs violate the provisions of Salutaris' foundation, they would be liable to seizure exactly as debtors of the Artemision and the gerousia would (p. 122). Two texts concern winners at the Megala Artemisia (31, 32). Oracles: The metrical oracle of Apollon about pestilance (23) has already been the object of detailed discussion [see $E B G R$ 1992, 84]. [AC]

133) D. KNOEPFLER, Le temple du Métrôon de Sardes et ses inscriptions, in MH, 50 (1993), p. 26-43 [BE 1993, 269]: An epigraphic dossier consisting of royal letters and decrees [EBGR 1989, 37] was published in the Metroion of Sardeis. The choice of this particular sanctuary may be due to the close connection of a prominent family of Sardeis to it; two prominent citizens have theophoric names deriving from Meter (Metrodoros, Metrophanes). These texts were to be inscribed ei $\zeta$ tìv

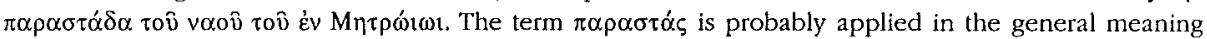
'entrance' ("c'est le sens d"entrée', de 'porche', etc., l'espace situé entre deux parastades pouvant être lui-même qualifié de $\pi \alpha \rho \alpha \sigma \tau \alpha \dot{\zeta} \zeta$ ou de $\left.\pi \rho \circ \sigma \tau \dot{\alpha} \varsigma^{\prime \prime}\right)$. K. proposes a reconstruction of the parastas of the temple in the Metroon, which has not been located yet. [AC]

134) D. KNOEPFLER, Adolf Wilhelm et la pentétèris des Amphiaraia d'Oropos, in M. PIÉRART, Aristote et Atbènes. Friboung (Suisse), 23-25 mai 1991, Paris, 1993, p 279-302: The pentaeteric lestival added to the Attic festivals under the archonship of Kephisophon (329/8; ARISTOT., Ath.Pol., LIV, 7) should be identified with the Amphiaraia of Oropos, as suggested by A. WILHELM and P. FOUCART, and not the Hephaisteia, as suggested by the traces of letters on the London papyrus. The early lists of victors at the Amphiaraia (IG VII $414+S E G 1,126$ ) may be attributed to the archonship of Kephisophon. [AC]

*135) L. KOENEN, The Ptolemaic King as a Religious Figure, in Self-Definition, p. 25-115: In this fundamental study on Ptolemaic kingship $K$. demonstrates how the Ptolemies managed to serve simultaneously the Greek and the Egyptian functions of their office through the amalgmatation of Egyptian and Greek elements. $K$. studies in detail the ruler cult and its development (the development of the eponymous state cults in Alexandria and the symbolic function of eponymous dating, the royal cult in the Egyptian temples, particularly as expressed in the royal titualary of Ptolemy $V$ Epiphanes in the Rosetta Stone) and shows that the Greek cult-names of the Ptolemies (Soter, Euergetes, Philadelphos, Philopator, Philometor, Epiphanes) captured many of the tenets of Egyptian titulary. These cult-names sound Greek to the Greeks, and yet the Egyptians could recognize in them their pharaoh. An analogous interdependence of the Greek and the Egyptian face of the Ptolemaic king can be recognized in the measures for the apomoira for temples and in the dynastic festivals, whose dates often follow the Egyptian ideology of kingship. The struggle of Greek culture to come to terms with the new environment is also clear in the poetry of Kallimachos, which occasionally transforms elements of Egyptian ideology into the language of Greek poetry. [AC] 
136) V. KONTORINI, La famille de l'amiral Damagoras de Rhodes. Contribution à la prosopograpbie et à l'bistoire rhodiennes, in Chiron, 23 (1993), p. 83-99: Ed. pr. of an honorific inscription for Euphranor, son of Damagoras, member of a prominent Rhodian family, who won the chariot race at the Halieia of Rhodos (Rhodos, 1st cent. BC). [AC]

137) R. KOTANSKY, $\Theta \omega \beta \alpha \rho \rho \alpha \beta \alpha v=$ 'The Deposit is Good', in HTR, 87 (1994), p. 367-369: The etymology of the vox magica $\theta \omega \beta \alpha \rho \rho \alpha \beta \alpha v$, very common in ancient spells, can be traced to Hebrew and means 'the deposit is good'. This commercial slogan, probably perceived as a sort of verbal oath, passed into the magician's vocabulary. [AC]

138) Ch. Koukouli-ChrysanthaKi - D. Malamidou, in $A D, 44$ Chron. (1989) [1995], p. 374-375: During the excavations in the sanctuary of Heros Auloneites (Kepia, Thrace) vases with dedicatory inscriptions adressed to the hero were found as well as a bronze tablet with the Latin dedicatory inscription of a Roman soldier. Many jars bear sealings inscribed with the words and $\theta \varepsilon o \hat{v}$, which indicate the production of pottery at this particular sanctuary. The jars were probably used for the storage of wine. $C f$. Ch. KOUKOULI-CHRYSANTHAKI - D. MALAMIDOU, Tó iepó tỗ

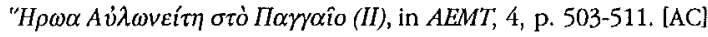

139) J. KUBínSKA, L' $\alpha \dot{\lambda} \lambda \dot{\eta}$ et le $\varphi \theta$ óvoৎ dans deux inscriptions du Hauran de l'époque du bas-empire, in Eos, 89 (1991) [1992], p. 195-198 [SEG 41, 1526]: K. studies inscriptions intended to protect an $\alpha \dot{\nu} \lambda \dot{n}$ (rural house, villa) from envy and the 'evil eye' (near Bostra, 6th cent.). The texts use formulas known also from pagan apotropaic texts: ó $\varphi \theta 0 v \omega \hat{0}$ ṕ $\alpha$ í $\tau \omega$ ("let him, who shows envy,

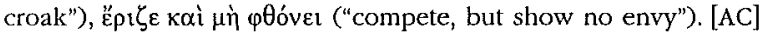

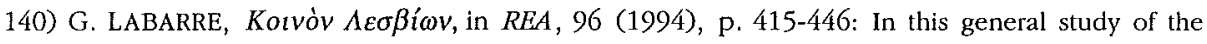
development of the Lesbian Koinon L. discusses in detail the history of the common sanctuary at Messa, known from epigraphic sources. This sanctuary became the center of a common cult of the cities of Lesbos sometime in the archaic or classical period; in the 2nd cent. BC it developed into the center of the Lesbian confederation. [AC]

141) Y. LAFOND, Pausanias et les paysages d'Achaie, in REA, 96 (1994), p. 485-498: Survey of the cults of Achaia mentioned by Pausanias with occasional references to epigraphy. [ES]

*142) M. LE GLAY, Héraclès - Hercule en Afrique du Nord, in Héraclès, p. 293-317: L. studies the religious and political aspects of the cult of Herakles in North Africa. Herakles' cult had deep roots in this area because of his identification with Melqart. Due to the importance of Melqart in Phoenician colonization, Herakles was perceived as founder of cities and was worshipped as protector of cities (Hercules conservator, genius civitatis) until imperial times. A second type of Herakles attested in North Africa is the hero of Greek mythology, who was assimilated with Melqart, suppressing indigenous features. From the Severan period on Herakles was also closely connected with the imperial ideology (Hercules Augustus) as protector of the emperor. In the 3rd cent. AD Herakles' cult acquired a more spiritual / 'mystical' character. [AC]

143) B. LEGRAS, Mallokouria et mallocourètes. Un rite de passage dans l'Égypte romaine, in $C C G, 4$ (1993), p. 113-127: A series of papyri as well as funeratry portaits attest a Greek rite of passage in Roman Egypt, the cutting of hair ( $\left.\mu \alpha \lambda \lambda_{\text {oxovpí }} \alpha\right)$ of young men upon entering adolescence. This ritual, known in mainland Greece from a variety of sources, was practiced by the members of

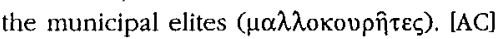

144) C. LETTA, Il dossier di Opramoas e la serie dei legati e degli archiereis di Licia, in Studi ellenistici, IV, p. 203-246: L. proposes a chronological rearrangement of the archiereis and the legati Augusti in Lykia in the period AD 103-152 and provides a new chronological table, which differs from the list constructed by M. WÖRRLE (Stadt und Fest im kaiserzeitlicben Kleinasien, Munich, 1988, p. 35-42) [EBGR 1988, 193]. [ES]

*145) P. LÉVÊQUe - A. VERBANCK-PIÉRARD, Héraclès, béros ou dieu?, in Héraclès, p. 43-65: In the first part of this article L. explores the bronze-age origins of the image of Herakles, suggesting that Herakles "est le troisième personnage d'une sainte famille de type néolithique dont les deux figures féminines, déesse mère / déesse fille, sont représentées par Héra et Athéna." In the second part, V. offers an insightful analysis of the methodological issues and the prolems with sources 
(archaeological, literary, and epigraphic) related to the very complicated question whether Herakles had a double nature as a hero and as a god [cf. EBGR 1990, 310]. [AC]

146) B. LEVICK - S. MITCHELL - J. POTTER - M. WAELKENS, Monumenta Asiae Minoris Antiqua. Volume X. Monuments from the Upper Tembris Valley, Cotiaeum, Cadi, Synaus, Ancyra, and Tiberiopolis Recorded by C.W.M. Cox, A. Cameron, and J. Cullen, London, 1993 $[B E$ 1995, 479]: The volume contains introductory chapters on the historical geography of the region (parts of Mysia, Phrygia, and the Phrygo-Mysian border), the Roman roads, the sculpture workshops, and Christianity, and presents 547 monuments, most of them inscribed; new texts are marked with an asterisk [cf. C. BRIXHE, in $B E 1995,479$, with several restorations and many remarks primarily on linguistic issues].

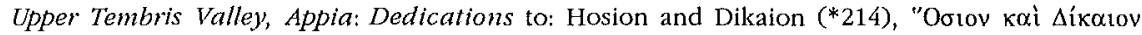

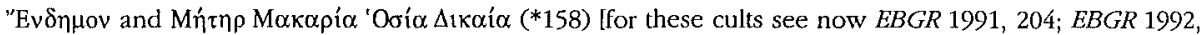

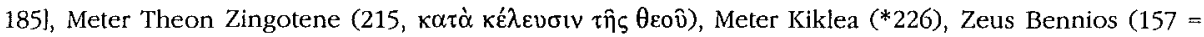
$S E G 40,1200$, for the welfare of Elagabalus and a village), Zeus (*222: $\Delta$ ì $\kappa \alpha i ̀ ~ ' E \rho \mu \alpha \beta \varepsilon v v \varepsilon \hat{i})$. The editors

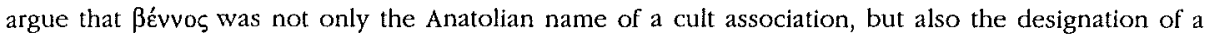

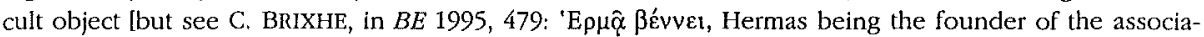
tionl. Cult officials: Two honorific inscriptions (*70 and 193, early 3rd cent.) were set up by the high priest of Asia M. Sestullius Severus Flavianus for his father. No. 198 is the epitaph of a priest. [The word iepev́s can be read also on the sarcophagus $\mathrm{n}^{\circ} 21^{*}$. Funerary cult: Numerous funerary impreca-

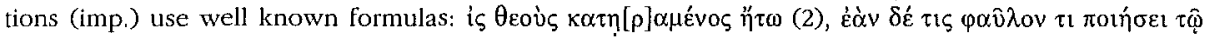

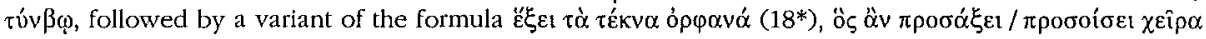

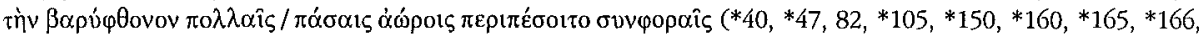

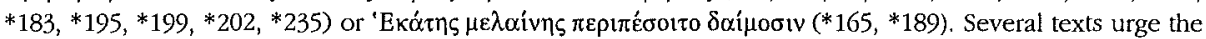

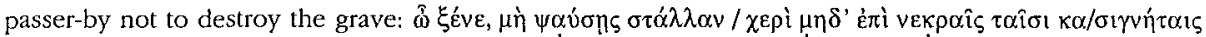

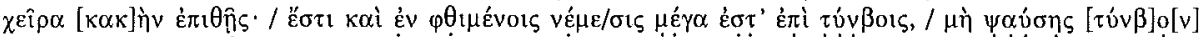

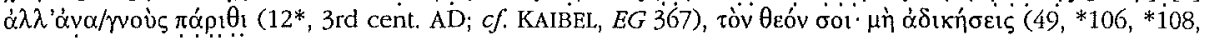

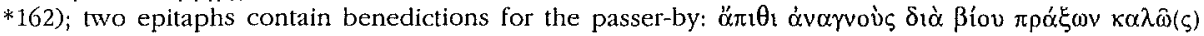

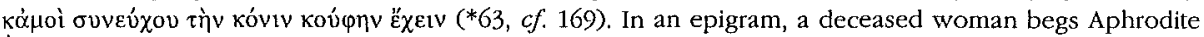

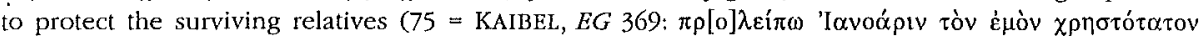

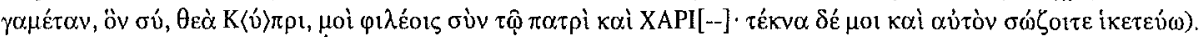
The care of the living for the dead is often expressed with the notion of $\operatorname{\varepsilon v\sigma } \varepsilon \hat{\varepsilon} \beta 1 \alpha\left({ }^{*} 40, * 60,{ }^{*} 218\right)$. A

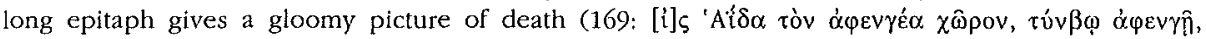
$\pi \circ \lambda \nu \beta \varepsilon ́ v \theta \varepsilon \varepsilon \tau \dot{v} v \beta \omega)$. An epitaph offers a unique variant of the topos that not death, but dying young is painful, suggesting that dying is not painful if the deceased had achicved something as valuable as

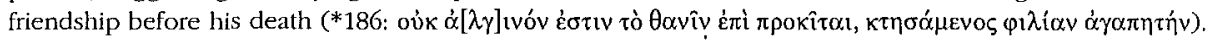
Two fragmentary epitaphs expressing thoughts about life after death are probably the work of

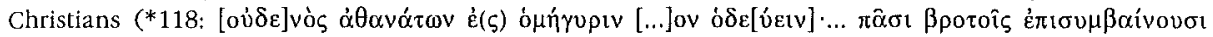

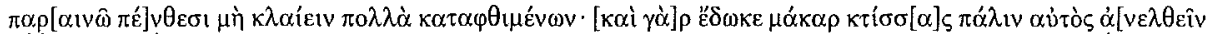

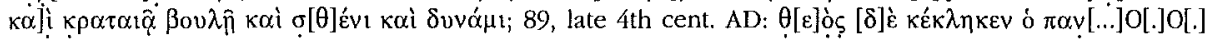

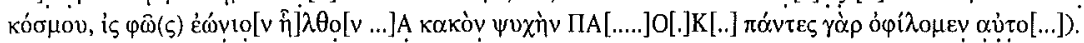

Kotiaion: Dedications to: Artemis $(* 344, \kappa \alpha \tau \dot{\alpha} \dot{\varepsilon} \pi 1 \tau \alpha \gamma \eta \dot{\eta})$, Meter Oriene $(* 307)$ [i.e., Oreine: C. BRIXHE, in $B E$ 1995, 479], Theos Hypsistos (262), Zeus Bronton $(290,294)$, Zeus and the Benneitai

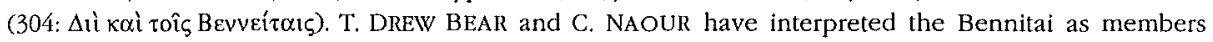
of a cult association ( $c f$. supra on the word $\beta$ Évvos). Funerary cult: Several funerary imprecations use

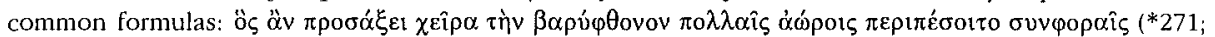

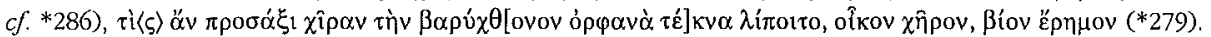

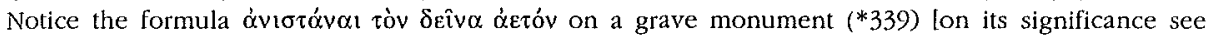

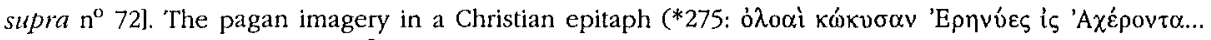

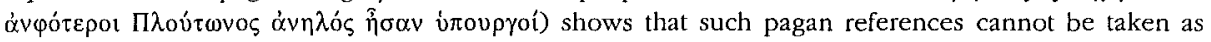
criteria of non-Christianity. Notice also the word $\alpha \omega \rho 0 \theta \alpha v \eta ! \zeta ~(* 308)$ [Cf. C. BRIXHE, in $B E$ 1995, 479].

Synaus: Dedications to: Helios Mithras ( $449=$ CIMRM 23), Meter Thea $(527=I G R$ IV 554), Thea Epekoos (*430), Theos Epekoos (*488, an altar and a $\pi v p \alpha ́ \mu \eta \varsigma=$ 'shovel'), Theos Epekoos Hypsistos $(* 504)$, Theos Hypsistos $(* 427, * 435, * 443)$, Theos Rhodios $(* 447)$, and Theos $(* 440)$. The addressee of

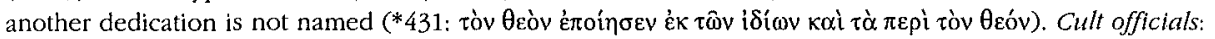


A high priestess of Asia in Ephesos (418), a priest (521), the grave of a priest and priestess (*439), the grave of an hieros (*437). An epitaph expresses thoughts about life after death $(517=C I G 3847$ and

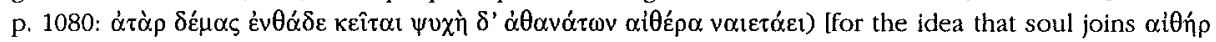
after death $c f$. parallels in $E B G R$ 1988, 32, 124, 179; 1989, 45]. [AC]

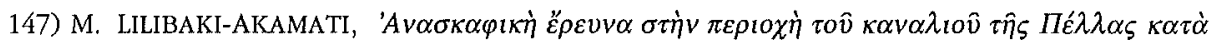
$\tau \dot{v} v \pi \varepsilon \rho i ́ o \delta o ~ 1988-1991$, in $A E M T, 5$, p. 83-95 [BE 1994, 414]: A dedication to Darron (= Tharron) Epekoos, a Macedonian healing deamon (HESYCH., s.v.), in fulfillment of a woman's vow was found in Pella, in a building complex which may have served as his sanctuary (2nd cent. BC). [AC]

148) J. LLOYD JONNES - W. AMELING, Inscriptions of Heraclea Pontica (IGSK, 47), Bonn, 1994 $[B E$ 1995, 5]: This corpus contains the inscriptions of and the testimonia on Herakleia Pontika in the Black Sea as well as a prosopography (compiled by A., p. 115-168); new texts are marked with an asterisk. Dedications: A physician dedicated of a statue of Hygieia to Asklepios (7, 2nd cent. AD). A dedication to the emperors (Theoi Sebastoi) and the Demos is inscribed on the rim of a weight (79a, no date). The ancient glory of the city is praised in a fragmentary dedication to Antoninus Pius and

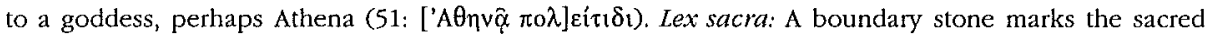

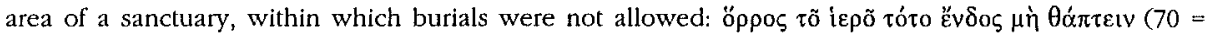
LSAM 83, ca. $400 \mathrm{BC}$ ). Sacred officials: Aurelius Alexander, high priest of Pontos is praised as

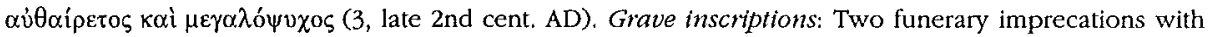

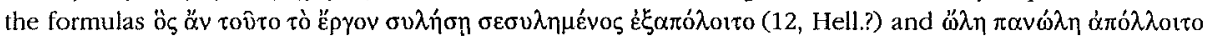
$\left(13^{*}, \mathrm{imp}.\right)$. Another epitaph provides for the payment of a fine for the violation of the grave (14*, imp.). The fragmentary epitaph of a mime (biologos) mentions the offering of incense on his grave,

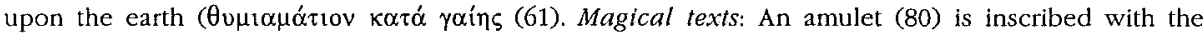
magical words $\alpha \beta \rho \alpha \sigma \alpha \xi$ and $-\Sigma I \Sigma P \Omega$ ('son of the ram', of Coptic origin, as noted by R. MERKELBACH). [ES]

149) Chr. LÖHR, Die Statuenbasen im Ampiareion von Oropos, in MDAI(A), 108 (1993), p. 183-212: The statue bases found in the Amphiareion at Oropos (late 4th-late 3rd cent. BC) can be divided into two groups, an earlier group set up in the west part of the main street (late 4th cent.-ca. 250), and a later group further east, erected after the demolition of the incubation room (ca. 230 BC). From the 1st cent. on the older bases were often reused for statues of Romans. The earlier group consisted primarily of equestrian statues of Hellenistic royalty, whereas the later group comprised primarily statues of the local aristocracy. The statues were dedicated both by individuals and by Oropos. $[\mathrm{AC}]$

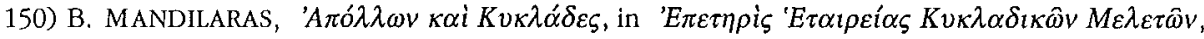
14 (1991-1993) [1993], p. 150-174: M. collects and discusses briefly the evidence for the cult of Apollon in the Cyclades, providing a list of inscriptions which attest this cult (p. 160-172). (This list includes neither the epigraphic evidence for month names related to festivals of Apollon nor the relevant theophoric names]. [AC]

151) G. MANGANARO, Iscrizioni "rupestri" di Sicilia, in Rupes loquentes, p. 447-501 [BE 1993 , 715; SEG 42, 820, 824-836, 850]: Collection and discussion of the Greek rock-inscriptions of Sicily (3rd cent. BC). Syracuse: The inscriptions inscised on the steps of the theater name members of the royal family (Hieron, Philistis, Nereis), Zeus Olympios, and Herakles Kraterophron. A inscription in the cave called Stella records the dedication of an altar and $\tau \rho \operatorname{i} \kappa \varepsilon \varepsilon v \alpha$ to the Nymphs by Aristoboula (IG XIV 4). The most interesting group of inscriptions, whose reading is revised by $M$. , was found in the rural sanctuary at Buscemi (1st cent. $\mathrm{BC} / \mathrm{AD}, \mathrm{p}, 452-487$ ) dedicated to the worship of the Paides $(1,4,6,8,9,10,11)$, Anna $(1,4-6,8,11)$, and Apollon $(4,8,9)$. The 11 texts were engraved by pilgrims, who visited the sanctuary ( $\pi \alpha \rho \varepsilon \gamma \varepsilon$ vov

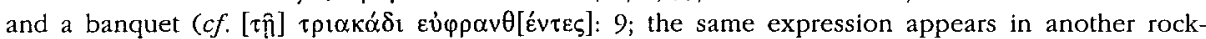
inscription in Adrano, p. 497), brought dedications ( $\alpha \vee \alpha=\theta \eta \alpha: 10$ ), and expressed their thanks

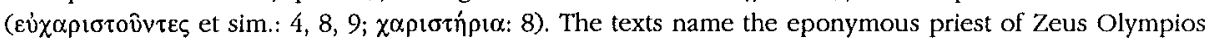

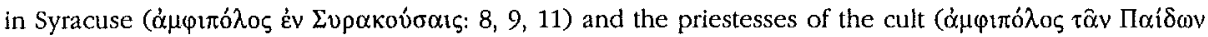

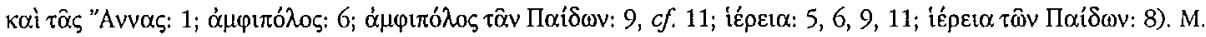

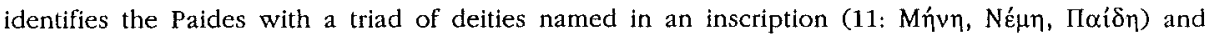
associates their cult with the Sicilian cult of the Materes [cf. infra $\left.\mathrm{n}^{\circ} 230\right]$ and the cult of Maia and 
Tetralea, attested in two enigmatic inscriptions found at Akrai (SEG 31, 821 and 822). According to $M$ 's restorations of the first text, Maia appeared to her priestess in a dream and gave her an oracle. The second text reproduces a dialogue between Tetralea and Zeus [on this text cf. EBGR 1987, 68]. [AC]

152) G. MANGANARO, Una dedica di Samo rivolta non a Leukaspis, ma a Hera Thespis, in $Z P E, 101$ (1994), p. 121-126: After a close examination M. proposes emendations to a dedicatory inscription found in Samos (BE 1965, 159). The text is addressed to Hera Thespis (not to Leukaspis); the dedicants came from the Sicilian city Endesa, where a cult and an oracle of Hera existed. M. argues that the epithet Thespis is related to $\theta \varepsilon \sigma \pi \varepsilon \sigma o s$ and means 'oracular'. [ES]

153) Ch. MAREK, Stadt, Ära und Territorium in Pontus-Bitbynia und Nord-Galatia, Tübingen, 1993 [ $B E$ 1995, 582-585]: In his general study of the area which corresponds to the province Pontos-Bithynia M. briefly presents the cults of Amastris (p. 98) and a corpus of the inscriptions of Pompeiopolis, Abonouteichos/Ionopolis, Amastris, and Kaisareia/Hadrianopolis (new texts are marked with an asterisk) (see the critical remarks of C. BRIXHE, in $B E$ 1995, 582, particularly on the divine epithets, which derive from place names, and on linguistic questions].

Pompeiopolis (p. 135-155): Dedications to: Agathe Tyche, Zeus, Helios, Sarapis, Isis and their synnaoi (24), Agathe Tyche, Zeus, Helios, Sarapis (*25, AD 268), Theos Doumouisenos (*27), Zeus Brontaios Xibenos (26). Cult officials: high priest $(2,21)$. Grave inscriptions: The grave epigram (probably of an Homerist) urges passers-by to enjoy life $(* 28)$; other grave epigrams mention the

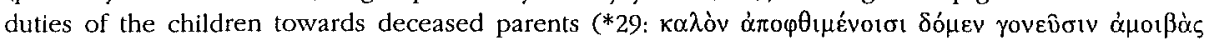

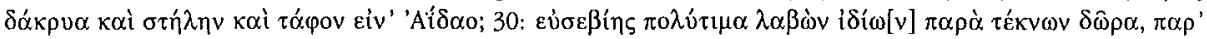

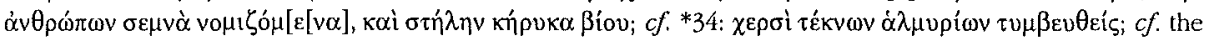

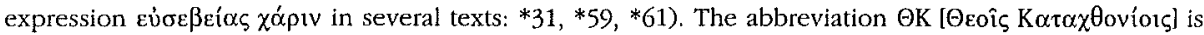
found in three epitaphs $(* 46, * 47, * 48)$. Several texts mention fines for the violation of graves (*32,

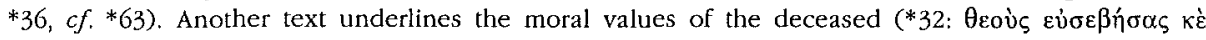

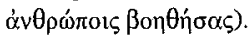

Abonouteicbos/Ionopolis (p. 155-157): A dedications to Zeus Poarinos ( 2 ; for his sanctuary cf. 1) and a high priest of the emperor cult (3).

Amastris (p. 157-187): Dedications to: Agathe Tyche (30), Agathe Tyche and Dionysos (28, by a

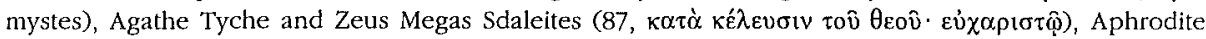

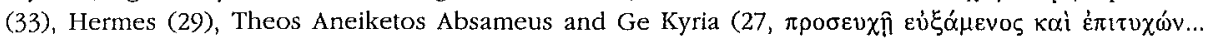

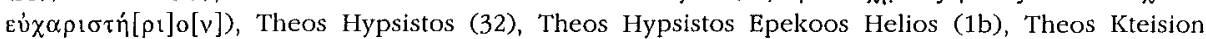
Epekoos and Tyche (26), Theos Monios (113), Zeus Gaini[os?] (96), Zeus Koropizos (96), Zeus Sarsos (112), Claudius and the Demos (2). Several ephebarchs dedicated altars and statues of a Satyr (10), Herakles (11, cf. 114), and the Demos (18); another altar was dedicated in fulfillment of a vow (34). An honorific inscription for two agoranomoi contains a prayer to Zeus Strategos and Hera, $\pi \alpha \tau \rho t o t$

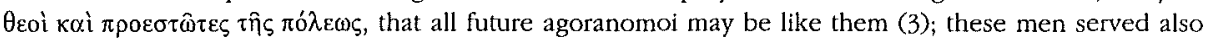
as high priests; their father had served as high priest for three successive terms and as agonothetes.

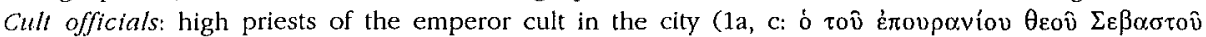

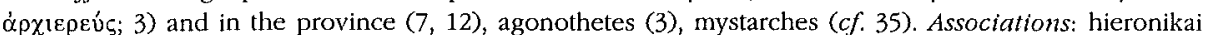
and hieranphodeitai (56) [C. BRIXHE, in $B E$ 1995, 582: "indication du quartier des vainqueurs aux

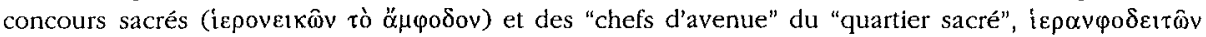

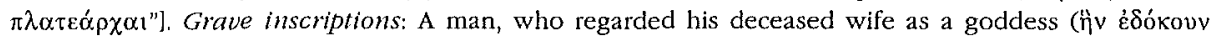

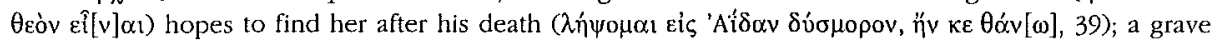
epigram mentions the participation of a young man in Dionysiac choruses ( $44=S E G 35,1327$; 40,

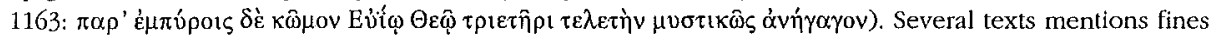
for the violation of graves $(60,61,63-70,72,88, * 110)$. The notion of evośpelo is used to describe the

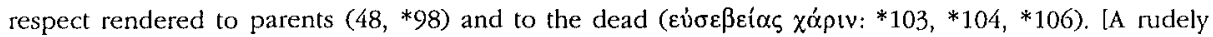
inscribed block $(* 116)$ is probably a curse ( $c f$. the expression $\alpha \pi \alpha \lambda i \psi\langle\eta \eta\rangle \hat{n} \gamma \varepsilon v / \varepsilon \hat{\alpha})$, related to the 'prayers for justice' studied by H.S. VERSNEL (see EBGR 1988, 184; 1991, 261). M. gives the following

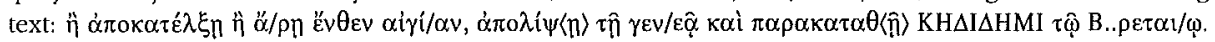

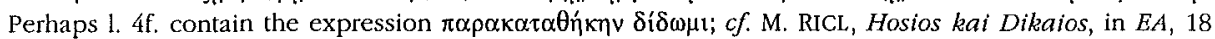

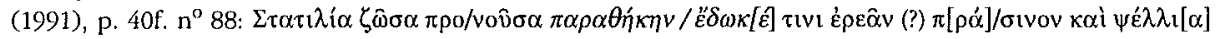

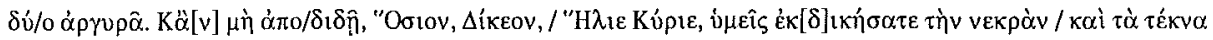




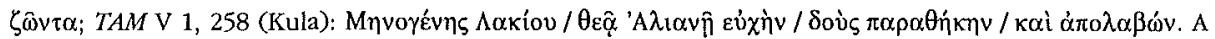
tentative translation would be "whoever draws down or takes away the $\alpha i \gamma i \alpha$ (?, 'goat's skin'?), let him and his descendants be destroyed. I have placed a pledge with B.,retaios (?)"].

Kaisareia/Hadrianopolis: Dedications to: Artemis Euktea (15, a temple), Artemis Kratiane (13,

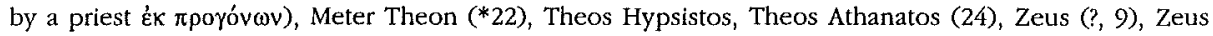
Baleos (18), Zeus Brontaios (17), Zeus Epekoos (23), Zeus Epidemios (19) [for Zeus Epidemios cf. supra $\mathrm{n}^{\circ}$ 82], Zeus Epikarpios (20), Zeus Es[-..] (*21), Zeus Karzenos (16), Zeus Kimistenos (14). An hiketes constructed and dedicated to Demeter and Kore a temple and statues, in obedience to their

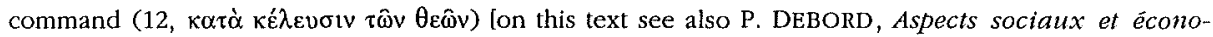
miques de la vie religieuse dans l'Anatolie gréco-romaine (EPRO, 88), Leiden, 1982, p. 355 note 72 ,

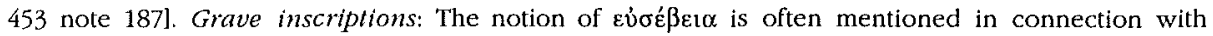
burials $(31,39,48,85, * 86)$. Three epitaphs underline the piety of the deceased (32: $\theta \rho \eta \sigma k \varepsilon v \sigma \alpha \nu \tau \alpha$

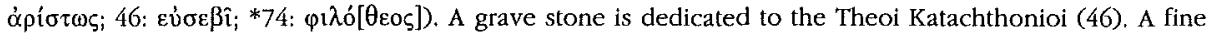
for the violation of the grave is mentioned in an epigram (81). A veteran is compared with Achilles and Hector (*79, for parallels see p. 107f.). [AC]

154) S. MARKOUlAKI, Archaeological Reports, in Kretike Hestia, 4 (1991/93), p. 207: M. mentions a base of a statue dedicated to Herakles (Kydonia, 5. Jh. BC). [AC]

155) A. MARTIN, Notes relatives à la dédicace $S B$ III 6184, in CE, 68 (1993), p. 212-218 [BE 1994, 686]: $M$. discusses an incription found in Ptolemais ( $S B$ III 6184, 138/7) which records the dedication of a sanctuary to the gods Thripis, Kolanthes, and Pan by the 28 members of a cult association (oi $\sigma u v o \delta i \tau \alpha \imath$ ) and their $\dot{\varepsilon} \pi \mu \varepsilon \lambda \eta \tau \dot{n} \varsigma$ Paniskos, high official of the court. The dedication was made for the welfare of Ptolemy VIII, Kleopatra II, and Kleopatra III, and shows the way cult associations expressed their loyalty by associating their respect towards the dynasty with the cult of local gods ( $c f$. the $\beta \alpha \sigma i \lambda t \sigma \tau \alpha i$ in Setis: ITbSy. 305. After a study of the onomastics of the dedicants $M$. supports the communis opinio that the members of this association were (primarily) soldiers. [ACl

156) A. MARTÍNEZ-FERNÁNDEZ, Notas sobre una inscripción métrica de Falasarna, in Fortunatae, 2 (1991), 319-330: M. discusses the magical verses written on a lead tablet from Phalasarna (Crete, 4th/3rd cent.) [unfortunatelly, with no knowledge of the new edition published later by D.R. JORDAN: $E B G R$ 1992, 112; cf. supra $\mathrm{n}^{\circ}$ 49], focusing on questions of dialect (mixture of koine and Dorian forms) and vocabulary (particularly the use of an epic vocabulary). [AC]

157) O. MASSON, Nouvelles notes d'antbroponymie grecque, in ZPE, 102 (1994), p. 167-184 [BE 1995, 169, 403]: $M$. discusses the name Noumenios ('child of the new moon') and studies the history of the personal name $\Delta$ ins along with its numerous variants. A concentration of this name on Lesbos and in the Aiolis can be observed, with sporadic examples from Asia Minor and Macedonia. [ES]

158) A. MASTROCINQUE, Orpbeos Bakcbikos, in ZPE, 97 (1993), p. 16-24 [BE 1994, 157]: $M$. demonsrates that an amulet in Berlin (O. KERN, Orphicorum Fragmenta, Berlin, 1922, $\mathrm{n}^{\circ} 150$,

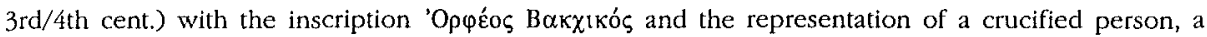
crescent moon, and seven stars, is not a forgery. The same inscription appears on three gems in private collections in 18th century Florence and Rome. The representation of the crucified figure cannot be of pagan origin. It is a representation of Jesus, who was often associated with Orpheus in early Christian literature and iconography. $[\mathrm{AC}]$

159) A. MATTHAIOU, Two New Attic Inscriptions, in Accounts Lewis, p. 175-188 [BE 1995, 87]: Ed. pr, of a dedication to Athena engraved on a statue base from the Acropolis (shortly after $350 \mathrm{BC}$ ). The dedicant, Philoumene, is the sister of Leosthenes, the Athenian general during the Lamian war (PA 9142). [ES]

160) R. MERKELBACH, Ein beiliger Baum der Heiden wird abgebackt, in ZPE, 96 (1993), p. 58: M. suggests that a Christian epigram published by G. WAGNER (ZPE, 96, 1993, p. 53f., Panopolis,

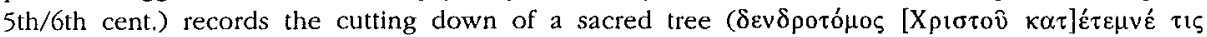

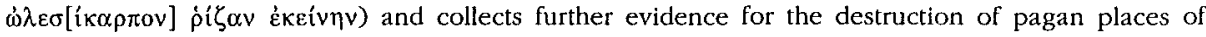
worship in late antiquity. $[\mathrm{AC}]$ 
161) L. MIGEOTTE, De la liturgie à la contribution obligatoire; le financement des Dionysies et les travaux du théâtre à lasos au IIe siècle avant J.-C., in Chiron, 23 (1993), p. 269-294 [BE 1994, 532]: 59 texts from Iasos (I.Iasos 160-218) record the contributions of citizens for the celebration of the Dionysia and the construction of the theater. This dossier illustrates the problems a small Hell. city faced when celebrating a festival. The texts can be divided into two periods: in the first period (ca. 196-185/180) the contributions consist of the payment of various amounts of money by choregoi and the performances of artists without an honorarium. The contributions of the second period (after ca. 185/180) are uniform (200 drachmas for citizens, 100 drachmas for metics). [AC].

162) T. MIKOCKI, Les impératrices et les princesses en déesses dans l'art romain, in Eos, 78 (1990), p. 209-218 [SEG 40, 1649]: M. uses the epigraphic and iconographic evidence (particulartly coins and gems) for the assimilation of female members of the imperial family with goddesses (Ceres / Demeter, Fortuna / Tyche, Isis, Juno, Diana, Kybele, Proserpina / Persephone, Nymphe, Charis, Venus / Aphrodite, Victoria, Caelestis, Roma, Minerva / Athena, Vesta / Hestia). This phenomenon continues Hellenistic traditions, but in addition to the goddesses, to whom Hellenistic queens were usually assimilated (Isis, Aphrodite, Demeter), the female members of the imperial family were assimilated to popular Roman deities and to abstract ideas. The assimilation usually had political motifs originating in Rome. From there it was imposed on the provinces. [AC]

163) M.C.J. MILlER, Two Inscriptions from West Lokris and Doris: a Reconsideration, in Boeotia Antiqua IV, p. 175-183: A dedicatoy inscription from Lokris [EBGR 1992, 219] has been

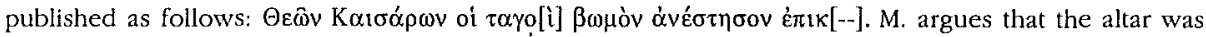
dedicated to honour all the emperors, living and dead, i.e., to the combined imperial Genius. An alternative to the reading $\tau \alpha \gamma_{0}[i]$, which would imply that this region had been assigned to the Thessalian koinon, is $\tau \alpha \dot{\gamma} \gamma \mu[\alpha \tau \sigma \zeta]$, an abbreviation of $\dot{\eta} \gamma \varepsilon \mu \grave{\omega} v \tau \dot{\alpha} \gamma \mu \alpha \tau o \zeta$. M. also proposes to restore $\dot{\varepsilon} \pi \dot{k}[\rho \mu \alpha \alpha]$ or $\dot{\varepsilon} \pi ı[\rho \dot{\mu} \mu \alpha \tau \alpha]$ on the last line. [This hardly makes any sense; other alternatives (e.g, $\dot{\varepsilon} \pi \dot{\mathrm{i}}$ $\mathrm{K}[--])$ are more probable]. [ES]

164) N.P. MILNER - M.F. SMITH, New Votive Reliefs from Oinoanda, in AS, 44 (1994), p. 65-76: Ed. pr. of votive reliefs found at Oinoanda. Two of them $(1,2)$ were dedicated by Licinnius Eutyches; the addressees are not named, but they are represented on the reliefs: the reliefs represent the Dioskouroi as horsemen flanking a female goddess (1) and a goddess accompanied by three epichoric warrior gods, commonly known as $\theta \varepsilon o i$ ö $\gamma p$ lo (2). The same triad of warrior gods is represented on $n^{\circ} 3$ (no inscription). An interesting monument was dedicated to the Synnaoi Theoi by the dadouchos Licinnius Hyakinthos $(4,2 \mathrm{nd} / 3 \mathrm{rd})$. It consists of a small apsidal niche over a tank (perhaps a fountain), with reliefs carved in rock-cut panels and representing the gods worshipped there. The dedicatory inscriptions identify them as the Dioskouroi Soteres (4a), Helios Mithras (4b), Hermes Prohegetes (4c), and Zeus Soter (4d). The epithet Prohegetes was unparalled for Hermes, but attested for Apollon and Artemis at Sidyma (TAM II 188); Hermes was conceived as a god who gave guidance. Three holes were cut for metallic attachments, probably the lamps which were lit by Hyakinthos, the keeper of the shrine. [AC]

165) P. VAN MINNEN, Drei Bemerkungen zur Gescbichte des Judentums in der griecbischrömiscben Welt, in ZPE, 100 (1994), p. 253-258 [BE 1995, 721]: M. discusses critically H. FELDMAN's theory of a massive proselytism in the Jewish diaspora (Jew and Gentile in the Ancient World, Princeton, 1993), pointing to the absence of a proselytizing literature, to the few attestations of proselytes, and to the fact that the large number of Jews in the 1st cent. $\mathrm{AD}$ can be the result of a plausible demographic increase. The list of Jews and god-fearers found in Aphrodisias (SEG 36, 970, 3rd cent. AD) [EBGR 1987,95; 1992, 209] shows that only three families were proselytes. The first line of this text should be restored as $\theta \operatorname{cò} \zeta \beta o \eta \theta \dot{\delta} \zeta \pi \alpha \tau \varepsilon \lambda \lambda \hat{\alpha} \delta \mathrm{o}[\zeta]$ or $\pi \alpha \tau \varepsilon \lambda \lambda \dot{\alpha} \delta \omega[\mathrm{v}]$ ('God, helper of the patella' or 'of the patellades', i.e. of the association of cooks). This line was a late addition and thus it does not prove the existence of the rabbinic institution of the 'soup kitchen' at Aphrodisias. [AC]

166) V. Missailidou-DESPOTIDOU, A Hellenistic Inscription from Skotoussa (Thessaly) and the Fortifications of the City, in ABSA, 88 (1993), p. 187-217 [BE 1994, 96; 1995, 336]: Ed. pr. of a decree of Skotoussa in Thessaly (ca. 197/185) concerning the description of a zone inside and outside the city walls which should not be private property. The text mentions the eponymous priest

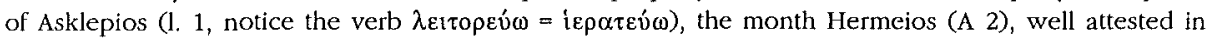


the Thessalian calendars but hitherto unattested in Skotoussa, and a series of sacred buildings: the Kerdoion (sanctuary of Apollon Kerdoios: A 71-75), the Herakleion (B 5), and the Helenelon

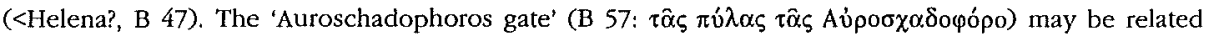
to a sanctuary of Dionysos or to a religious procession in which vine branches were carried ( $\alpha \dot{v} p o \sigma \chi \alpha ́ \varsigma$ is according to ERATOSTH. 37 'a branch of vine with bunches of grapes') [cf. the Athenian Oschophoria]. [AC].

167) S. MITCHELl, Anatolia: Land, Men, and Gods in Asia Minor, Oxford, 1993 [BE 1995, 463, $565-568,572,573,592$ ]: I single out the most important subjects of religious interest treated by $M$. in his extremely important contribution to the history of Asia Minor (esp. central Asia Minor) from ca. the 2 nd cent. $\mathrm{BC}$ to the 6 th cent. $\mathrm{AD}$. The first volume deals, among other things, with the religious practices of the Galatians (p. 47-50), the introduction and development of the emperor cult (p. 100117 ), the forms of worship and the religious mentality in rural communities (p. 187-195, e.g., invocation of gods to inflict punishment, confession inscriptions, rural sanctuaries, particularly the sanctuary of Apollon Lermenos), and the agonistic festivals (p. 217-225). The second volume, which is primarily devoted to the rise of Christianity, includes discussions of the pagan worship in the first three centuries (p. 11-19), the indigenous cults of Anatolia (esp. Zeus, Meter, Mes, Hosion kai Dikaion, and Ares, p. 11-30), the existence of Jewish communities (p. 31-37), and the persistence of pagan culture in 4 th cent. Ankyra (p. 84-91) [ $c f$. the remarks of C. BRIXHE, in $B E 1995,463$, primarily on linguistic issues]. M. presents (vol. II, p. 20f. and 26f.) several unpublished reliefs from Phrygia, dedicated to Artemis (fig. 13), Hekate (fig. 10), Hosion kai Dikaion (fig.14) [see now EBGR 1991, 204], Zeus Abozenos (fig. 7, an anatomical votive, with the representation of a leg), Zeus Petarenos (fig. 9), and Zeus Thallos (fig. 6). One relief dedicated to Theoi Basileis was found near Antiocheia in Pisidia (fig. 12). $[\mathrm{AC}]$

168) S. MITCHELL, Three Cities in Pisidia, in AS, 44 (1994), p. 129-148: In a topographical study on Kretopolis, Panemoteichos, and Kodrula M. publishes (p. 139) an honorific decree for C. O[---]us Sempronius Visellius, high priest of the emperors and agonothetes at Panemoteichos (3rd cent. AD). $[\mathrm{ACl}$

169) G. NÉMETH, Hekatompedon-Probleme, in ZPE, 101 (1994), p. 215-217 [BE 1995, 63]: Revised edition of the first 20 lines of the Athenian inscription concerning the protection of the Hekatompedos on the Athenian Akropolis (IG $\mathrm{I}^{3} 4$, ca. 499/8 or 498/7) [cf. G. NÉMETH, Übersetzung und Datierung der Hekatompedos-Inschrift, in JdI, 108, 1993, p. 76-81]. [ES]

170) G. NEUMANN, Beiträge zum Kypriscben, in Kadmos, 32 (1993), p. 39-49: The month name

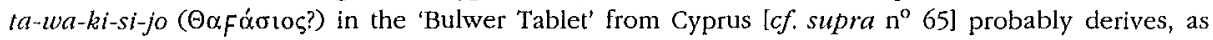
other Cypriote month names, from a divine name or epithet. It may be an epithet of Apollon

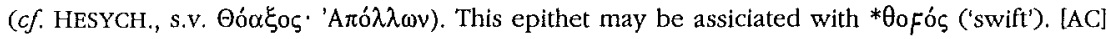

171) I. NICOLAOU, Inscriptiones Cypriae Alphabeticae XXXI, 1991, in RDAC, 1992, p. 257-262 [BE 1993, 612; 1994, 129; SEG 42, 1312, 1318]: Ed. pr. an inscription recording the dedication of an

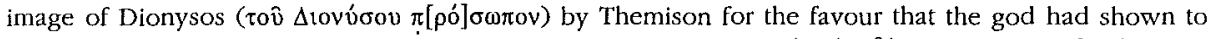

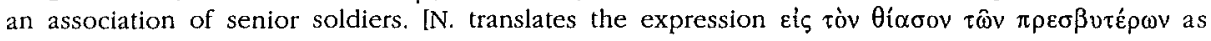
follows: "in fulfilment of a vow (made to the god) for the prosperity of the association of the senior military servicemen"; the expression rather implies that the dedication was made in a shrine of the association]. The dedication of an image of Dionysos probably expressed the loyalty of the soldiers, since this god was particularly related to the Ptolemies. (13, Kition, mid-3rd cent. BC). Ed. pr. of an inscription recording the dedication of a statue of Glykon to Aphrodite Paphia by his parents in fulfillment of a vow (15, Paphos, 2nd/1st cent.). [AC]

172) I. NICOLAOU, Inscriptiones Cypriae Alphabeticae XXXII, 1992, in RDAC, 1993, p. 223-232 [BE 1995, 605]: Ed. pr. of numerous inscriptions found in Cyprus. Amatbous: A dedication to Theos Hypsistos (1, 2nd/3rd cent.); N. collects another 24 published dedications to Theos Hypsistos from various sites on Cyprus. Papbos: An altar dedicated to Arsinoe II Philadelphos (5, ca. 277/270). N. presents all the published inscriptions which attest the cult of Arsinoe, both the official ( 6 texts) and household cults (19 texts). [AC] 
173) P.M. NIGDELIS, Synagoge( $n$ ) und Gemeinde der Juden in Thessaloniki: Fragen aufgrund einer neuen jüdischen Grabinschrift der Kaiserzeit, in ZPE, 102 (1994), p. 297-306 [BE 1995, 424]: Ed. pr. of a Jewish funerary inscription (Thessalonike, 2nd/3rd cent. AD) mentioning

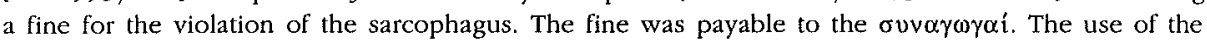
plural does not necessarily imply the existence of more than one synagogue in Thessalonike; it may refer to other buildings belonging to the synagogue. [ES]

174) J. NOLLÉ, Side im Altertum I (IGSK, 43), Bonn, 1993 [BE 1994, 599]: In the first volume of his exhaustive study on Side $\mathrm{N}$. discusses the topography, the history, and the cults of the city until the 3rd cent. AD. In the chapters dedicated to the floruit of Side in the 2nd and 3rd cent. (p. 80-95) N. discusses important building programs (temples of Athena and Apollon, Nymphaion), the civic agons (particularly the pentaeteric agon mystikos dedicated to Demeter and Dionysos, the epibaterios agon in honour of Athena and Apollon, and the agon Phoibeios, renamed later to Agon Apolloneios Gordianeios Antoneinios or Pythia, Olympia), and the competition between the cities of Asia Minor for the rank of 'the first city' ( $\pi \rho \omega \tau \varepsilon i \alpha)$, the title of neokoros, and other privileges [cf. infra $\mathrm{n}^{\circ}$ 175]. The cults of Side are presented on the basis of inscriptions, coins, theophoric names, and archaeological monuments (p. 105-125). The most important cults were those of the

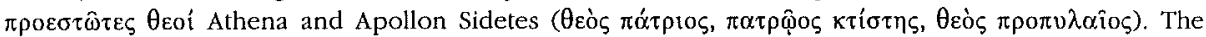
festival $\dot{\varepsilon} \pi \beta \alpha \tau$ mplos in honour of Apollon and Athena was probably associated with navigation. The emperor cult, particularly prominent in Side, which received six neokories, was associated with that of other deities (Athena, Apollon, Asklepios, and Dionysos), as we may infer from their designation as neokoroi. Other deities worshipped in Side were Aphrodite, Ares, Artemis, Asklepios, (Athena?) Boulaia, Demeter (Anarsitike), Dionysos, Helios, Hephaistos, Herakles, Hermes, Isis and Sarapis, the local goddess Klea, Kybele, Nemesis, Poseidon Asphaleios, Dea Roma, Themis, Theoi Megaloi, Tyche ( $c f$. the existence of a Tycheion) and Zeus (Halonites, Norites, Nikator). The cult officials include the priestesses of Athena, Demeter, Themis, the priests of Apollon and Dionysos, and the kleidophoros of Isis and Sarapis. Some priests / priestesses served for life (Athena, Themis) or for a pentaeteris

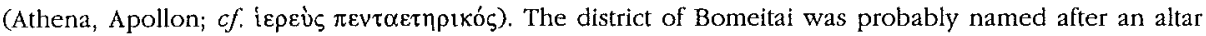
of Zeus (p. 115). The volume also contains the literary sources on the city (p. 147-194), the epigraphic testimonia on Side found in other places (p. 195-249), a few papyri (p. 251-254), and the first part of the corpus of the inscriptions of Side $\left(n^{\circ s} 1-69\right)$; $N$, discusses all the testimonia in detail. Since these texts have been exploited by $N$. for the chapters dedicated to the cults of Side, they will not be

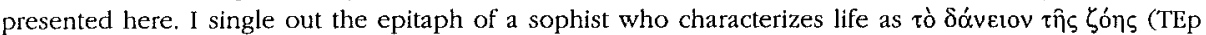

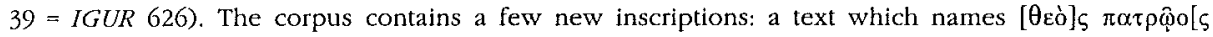

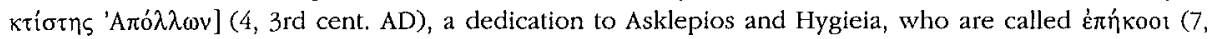
2nd/3rd cent.), a dedication to Helios $(9,2$ nd cent. $A D)$, a vow (21, imp.), and a small fragment of an alphabetical oracle (23) [on alphabetical oracles $c f . E B G R$ 1992, 160 and 179]. [AC]

175) J. NOLLÉ, Die feindlichen Scbwestern. Betrachtungen zur Rivalität der pampbyliscben Städte, in Erforschung Kleinasiens, p. 297-317: N. presents and discusses the epigraphic and numismatic evidence for the rivalries between the cities of Pamphylia (particularly between Perge and Side) for the rank of the 'first city', the title of neokoros, and the right of asylia in imperial times. $[\mathrm{AC}]$

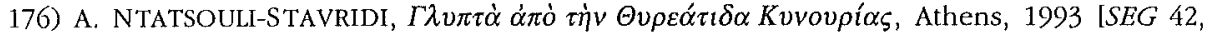
366]: N. publishes the works of sculpure found in Thyreatis (Peloponnese). A relief with the representation of a funerary banquet is dedicated to the hero Polemokrates (p. $24 \mathrm{n}^{\circ} 2$; 4 th cent. BC) [cf. $E B G R$ 1990, 85]. A dedicatory relief with the representation of a woman seated on a throne, a woman carrying a basket with fruits, and the statue of a deity (Artemis?) hanging on a tree bears the

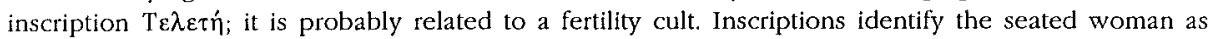
Epiktesis [not Epiklesis, as in the commentary] and the standing woman with Euthenia (p. 27f., $\mathrm{n}^{\circ} 1390$, Eua, 2nd cent. AD). [This monument is also published by M.-O. JENTEL, Euthénia. Corpus des monuments et étude iconograpbique, Québec, 1993, p. 187f., fig. 148-150; $c f . B E$ 1994, 71]. [AC]

177) S. PALigA, La divinité suprême des Tbraco-Daces, in DHA, 20.2 (1994), p. 137-150: P. studies the Thracian divine names Zalmoxis (Zamolxis, Salmoxis) and Gebeleizis from a linguistic point of view. Gabeleizis is probably an epithet of Zalmoxis, and not a separate deity. [ES] 
178) A. PANAYOTOU - P. CHRYSOSTOMOU, Inscriptions de la Bottiée et de l'Almopie en Macédoine, in BCH, 117 (1993), p. 359-400 [BE 1994, 390, 401, 403, 404, 405, 406, 408, 417]: Ed. pr. of 25 inscriptions found in Bottiaia and Almopia in Macedonia. Bottiaia, Edessa: A female slave of Syrian origin was freed through dedication to Parthenos, i.e., a local goddess or Dea Syria $(1,2$ nd cent. BC) [cf. $E B G R$ 1992, 47]. A $\pi \alpha 1 \delta \varepsilon v \tau \eta$ c dedicated an Hermaic stele with the image of Herakles (2, 3rd cent AD) [EBGR 1989, 19]. Anydron: A dedication to Zeus Hypsistos (6, AD 164?), Mandalon: An inscription (7, late 4 th cent. $B C$ ) records the organization of an agon (horse race, foot race); the

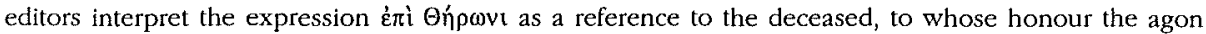
was dedicated (M. HATZOPOULOS, however, suggests that this text commemorates an initiatory ritual; see supra $\mathrm{n}^{\circ}$ 110]. Kyrrbos: Record of a manumission in the form of dedication to Artemis (11, 2nd/3rd cent.). Giannitsa: In the record of a manumission of slaves dedicated to Thea Syria

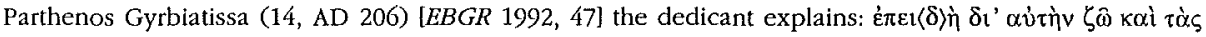
$\dot{\alpha} \rho \varepsilon \tau \dot{\alpha}, \varsigma \alpha \dot{\tau} \hat{\eta} \zeta$. The editors offer parallels for the dedication of slaves as expression of gratitude for healing. Agriosykia: Dedication of the statue of an eagle (to Zeus Hypsistos?) as a vow (20, 3rd cent.

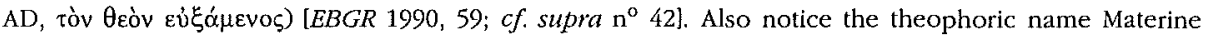
(<Meter, 3, 1st/2nd cent.). Almopia, Promacboi: A dedication to Artemis Agrotera, made from the revenues of her sanctuary (23, late 4 th cent. BC) [cf. supra $\mathrm{n}^{\circ}$ 40]. [M. HATzOPOULOS, in BE 1994, 401, recognizes in the small fragment $n^{\circ} 22$ a dedication to the goddess Ma; the dedicant had constructed

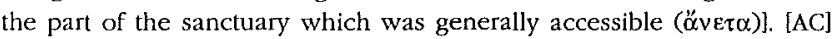

179) A. PANEV - M. RICL, Nouvelles inscriptions votives de Macédoine orientale, in ZPE, 101 (1994), p. 139-150: a) New edition of inscribed votive plaques from the sanctuary of Bargala (2nd/3rd cent. AD). The dedications are addressed to Zeus $(6,10)$ and to the Thracian Theos He[ros?] (1) and [Theos/Heros?] Mestenos (2); the epithet Mestenos is otherwise unattested [on the numerous epithets of the Thracian hero with the ending -nvós see EBGR 1990, 78]. b) New edition of an inscribed votive plaque dedicated to Soter Asklepios found in Crvulevo $(23,3$ rd cent. AD). [ES]

180) E. PAPAKONSTANTINOU, in $A D, 44$ Chron. (1989) [1995], p. 102-103: P. presents a dedication to Aphrodite by Phila, who served as theokolos (Elis, 2nd cent $\mathrm{BC}$ ). [AC]

181) R. PARKER, Artemis Lemnia, in ZPE, 99 (1993), p. 122: A decree of Myrina found in Athens (IG $\mathrm{II}^{2}$ 1224) shows that the sanctuary of Artemis Lemnia was the place where public documents were published in Myrina, making it the major civic sanctuary of Myrina. The series of decrees of 'the demos of the Athenians at Myrine' $(I G$ XII 8,2) was probably found in this sanctuary. [AC]

*182) R. PARKER, Atbenian Religion Abroad, in Accounts Lewis, p. 340-346: P. examines the Athenian religion in the Attic settlements abroad as a remarkable case-study of the interconnection between the established religious order at home and the new conditions in areas where new settlements were founded. The Athenian klerouchies of the 5th cent. differ from the 'old' foundation of colonies: the consultation of oracles is not attested, the role of an oikistes was lost, and the klerouchies were placed within the territories of existing Greek states. These differences seem to have influenced the religious life of the Attic klerouchs: a) The klerouchs maintained contact with the gods of Athens, the city which they still regarded their own. They often made collective dedications in the temples of Attika (e.g., the 'Lemnian Athena' of Pheidias on the Acropolis, dedicated by the Athenian settlers on Lemnos). b) The klerouchs, as newcomers to territories with established religious traditions, respected the local gods, even though they tended to make adjustments to please their own taste. The klerouchies of the 4th cent. were small-scale replicas of Athens. This can be seen in the introduction of the Dionysia ( $I G$ XII 8, 4 Myrina, Lemnos), in the existence of prosperous orgeones devoted to the cult of a hero (Herakles at Kome: IG XII 8, 19 1. 21, Myrina), or in the adoptation of the Athenian tribal system on Samos and the offering of separate sacrifices to the ten tribal heroes (G. KLAFFENBACH, in $M D A I(A), 51,1926$, p. $36 \mathrm{n}^{\circ}$ ). An enigmatic sacrificial calendar of the 5th century found in Euboia $\left(I G \mathrm{I}^{3} 255\right)$ is probably that of a klerouchy at Chalkis. In this calendar a single Euboean hero is mentioned among Attic gods and heroes. P. also discusses the atypical and remarkable case of the Athenian klerouchies in Lemnos. Lemnos exemplifies the enthusiastic adoption by Greek colonists of pre-Greek forms of worship. From the inscriptions ( $S$. ACCAME, in $A S A A$, NS $3 / 5,1941 / 43$, p. $75-105$ ) we may infer that the cult of the Great Gods of Lemnos was just as important to the Athenians in Lemnos as the cult of Demeter and Kore was to the Athenians in Athens. The 
acceptance of local traditions is also evident in the worship of Artemis, Hermes, and the ithyphallic god Orthanes by the Athenian klerouchs in Lemnos and Imbros. [ES]

183) K. PARLASCA, Zeugnisse ägyptischer Kulte in Lykien, in Lykien-Symposion, vol. 1, p. 249252: Presentation of the epigraphic, numismatic, and iconographic evidence for the worship of Isis and Sarapis in Lykia. $[\mathrm{AC}]$

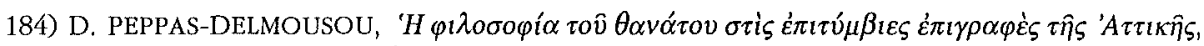
in Aphieroma Vanderpool, p. 67-78: P. presents a small selection of grave epigrams of Attika and discusses the attitudes towards death and the eschatological beliefs attested in them, especially the idea that just persons may expect a better treatment after death, e.g., in W. PEEK, Griechiscbe

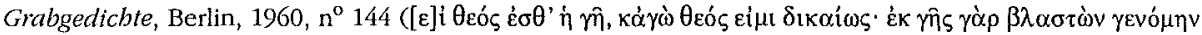

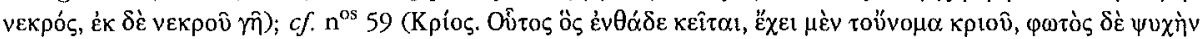

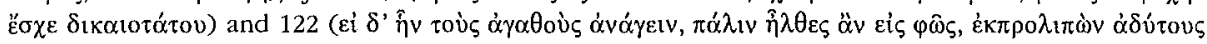

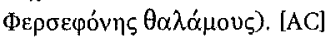

185) P. PERLMAN, Inscriptions from Crete, $I$, in ZPE, 100 (1994), p. 123-125 [BE 1995, 460]: a) Ed. pr. of an inscription from Knossos (2nd/1st cent.) which records building works probably in a sanctuary (2, cf. 1. 4: $\pi \alpha \sigma \tau \alpha \dot{\delta} \delta \mathrm{o}$ ) (cf. now A. CHANIOTIS, Kretische Inschriften, in Tekmeria, 1 (1993), p. 31f.]. b) A lex sacra from Knossos (SEG 35, 989, 2nd/1st cent.) concerns the cult of Artemis Skopelitis worshipped by the association of the Epilykoi. P. argues that the Epilykoi were worshippers of Apollon Lykeios. Another Knossian inscription is dedicated to Apollon Lykeios and his oúvvoor (I.Cret. I, viii 15); if Artemis Skopelitis is one of Apollon's synnaoi, the sanctuary of Apollon Lykeios should be located in Ano Fortetsa. The expressions $\kappa \alpha \tau \dot{\alpha} \pi \rho o ́ \sigma \tau \alpha \gamma \mu \alpha$ and $\kappa \alpha \tau \dot{\alpha}$ É $\pi \tau \tau \alpha \gamma \alpha$ v used in the two texts indicate that the divine will (request of the dedication, approval of the lex sacra) was expressed through oracles (rather than through dreams). [ES]

186) F. PESANDO, Nota di topografia Delia, in Ostraka, 2 (1993), p. 105-115: From the inscrip-

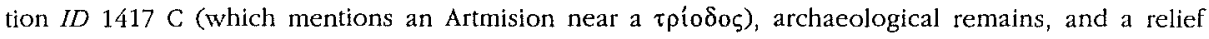
with the representation of Artemis Soteira (ID 2379) P. infers the existence of a separate sanctuary of Artemis on Delos, in addition to the one within the sanctuary of Apollon. This Artemision should be identified with 'the sanctuary of the bastion'. [AC]

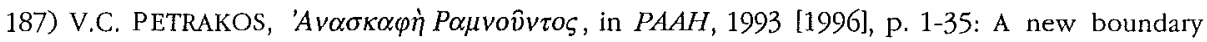
stone of the shrine of Heros Archegetes was found in a small shrine excavated in Rhamnous (p. 25). The shrine, however, cannot be attributed to this cult. $[\mathrm{AC}]$

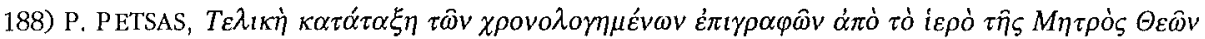

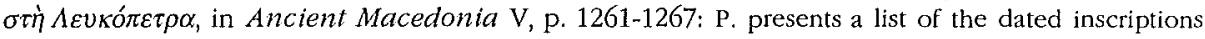
(almost exclusively manumission records) found in the sanctuary of Meter Theon in Leukopetra (Macedonia); they range between AD 145 and 313. He also presents briefly an altar with 5 manumis-

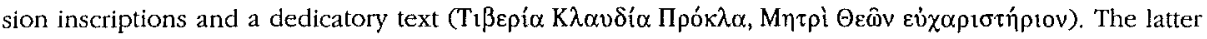
is the earliest dated text from the sanctuary (AD 145). [AC]

189) M. PIÉRART, Les bonneurs de Persée et d'Héraclès, in Hêraclès, p. 223-244 [BE 1994, 336;

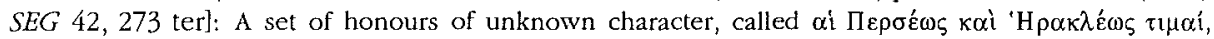
appear among the honours awarded by Argos to benefactors in imperial times. Indeed, numerous inscriptions attest the association of the two heroes with Argos. Perseus and Herakles were often considered 'founders of cities' and played an important part in the mythological self-representation of $\mathrm{Argos}$ and in its relations with cities of Asia Minor, in periods when mythological genealogies and mythological relationships between cities were very common [on this subject see now O. CURTY, Les parentés légendaires entre cités grecques, Genève, 1995; cf. infra $\mathrm{n}^{\circ}$ 216]. However, while the myths of Perseus occupy a prominent position in Pausanias' description of the monuments of Argos, Pausanias neglects to mention monuments related to Herakles. This is even more striking, since epigraphic sources attest cults of Herakles in the territory of Argos and since this hero is often mentioned in other parts of the periegesis, e.g., in relation to Troizen. The different treatment of Perseus and Herakles probably reflects the situation in the 2nd cent. AD, when Perseus had acquired a priority as the Argive hero par excellence and had become far more important for the collective identity of the Argives than Herakles. [AC] 


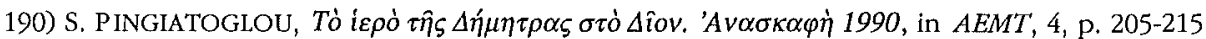
[BE 1994, 388]: In her report on the 1990 excavation in the sanctuary of Demeter at Dion P. presents an unpublished inscribed cup dedicated to Demeter. [AC]

191) M. PIZzocAro, L'inno di Epidauro alla Madre degli Dèi $\left(I G^{2}, I V, 131=\right.$ Telesilla 2 Diebl ${ }^{2}=$ PMG fr. adesp. 935), in AION (fil.), 13 (1991) [= L'inno tra rituale e letteratura nel mondo antico. Atti di un colloquio, Napoli 21-24 ottobre 1991, Rome, 1993], p. 233-251 [SEG 42, 294]: P. gives a new edition of the hymn to Meter Theon from Epidauros (3rd cent. AD, $I G \mathrm{IV}^{2} 1$, 131) [cf. EBGR 1992, 239] and suggests that the hymn, perhaps one of the $\mu \eta \tau \rho \hat{\alpha} \alpha \mu \varepsilon^{\prime} \lambda \eta$ (DION. HAL, Ant. Rom., II, 19, 4), was composed in the 4th cent. BC. Its content corresponds to the mythological and cultic traditions related to Meter Theon. The structure of the Epidaurian hymn is similar to the structure of the Homeric hymns, but differs from that of the Orphic hymns. P. discusses the evidence for the association of Meter Theon with healing and her cult in the Asklepieion of Epidauros (IG IV $1001,1002,1034,1308$ ). [AC]

192) G. PUGLIESE CARRATELli, Epigrafi onorarie di Iasos in Caria, RAL, Ser. 9, 4 (1993), p. 261-269 [BE 1994, 102]: Ed. pr. of three honorific inscriptions from Iasos, 1) An honorific inscription for the benefactor Potens was erected in front of the Kaisareion. This stele lists his benefactions. Among other things Potens had dedicated a phiale to Isis and Sarapis, had erected a statue in the Kaisareion (?), and had financed the banquet ( $\tau$ pík $\lambda$ ivov) held for the council and the magistrates during the celebration of the birthday of emperor Claudius (1st cent.). 2) M. Aurelius Daphnous Kataplous is honoured for his public services. He served as stephanephoros and high priest of the civic cult of three emperors (Septimius Severus, Caracalla, Geta?). On the occasion of the dedication of the statues of the emperors Daphnous distributed aromatic wine. [P. assumes that the $\sigma \tau \varepsilon \varphi \alpha v \eta$ popia, which took place on that occasion was the crowning of the statues: "ai concelebranti dei riti dell'incoronazione (delle statue degli Augusti)"'. Daphnous probably organized a stephanephoria of

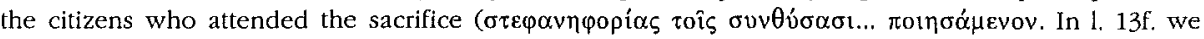

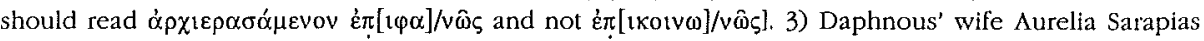

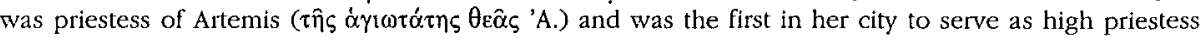

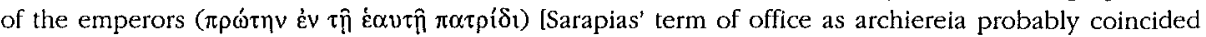
with that of her husband; she was the first woman in Iasos who served as high priestess together with her husband, and not in her own right. On this question cf. supra $\mathrm{n}^{0 \mathrm{~s}} 33$ and 85, and infra $\left.\mathrm{n}^{\circ} 205\right]$. $[\mathrm{AC}]$

193) N.K. RAUH, The Sacred Bonds of Commerce: Religion, Economy, and Trade Society at Hellenistic Roman Delos, Amsterdam, 1993: R.'s study, which focuses on the presence of Roman traders on Delos (166-88 BC), includes a discussion of their religious activities, i.e., the religious remains in the principal commercial complexes ('Agora of the Italians', 'Agora of the Compitaliastai', p. 81-108), the rôle of oaths in commerce (p. 132-150), the religious mentality of the Roman merchant (oaths, curses, worship of Hermes/Mercurius and Herakles/Hercules, p. 151-188), the religious activities of associations (žpavor, collegia, esp. Hermaistai and Compitaliastai), and the dedication in the 'Agora of the Italians' (p. 295-322). This evidence suggests that the Graeco-Roman business community in late Hellenistic Delos depended heavily on religious forms and institutions to organize its trade: gods, who were universally revered, witnesed the transactions, and religious associations brought merchants of various nationalities and backgrounds together. [AC]

194) G. REGER, Two Estates of Delian Apollo on Mykonos and the Date of ID $452+467$, in Hesperia, 63 (1994), p. 105-110 [BE 1995, 438]: R. comments on the inscription $I D 452+467$, which records the lease of the estate Dorion - Chersonesos and presents the earliest known inventory for the Delian estate Epistheneia. R. dates the inscription during the archonship of Oineus in Delos (177 BC). [ES]

195) J. REYNOLDS - Ch. ROUECHÉ, The Funeral of Tatia Attalis at Apbrodisias, in Ktéma, 17 (1992) [1996], p. 153-160: Two new fragments of the decree of Aphrodisias concerning the funeral of Tatia Attalis, priestess of the emperors and member of a prominent family, were found ( $c f . R E G$, $19,1906, n^{\circ}$ 9, 2nd cent. AD). The new fragments show that Attalis, called $\dot{\eta} \rho \omega i \zeta$ (B 4), was honoured with burial within the city, in the grave of her grandfather Adrastos, with the dedication of images 


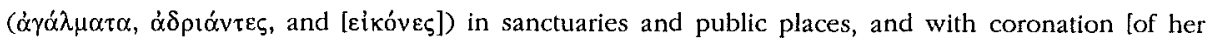

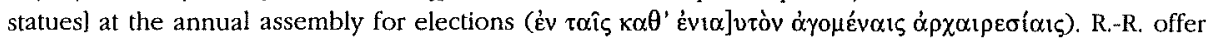
parallels for these honours as well as for the spontaneous expression of public grief at the announcement of Attalis' death (seizure of her bier, perhaps by a civic organization, acclamations, decree, public funeral). [ACl

196) M. RICL, New Greek Inscriptions from Pelagonia and Derriopos, in ZPE, 101 (1994), p. 151-163: Ed. pr. of a funerary stele from Nikodin $(5,2$ nd cent. AD), which mentions a priest of Dionysos. Dionysos' cult is very prominent in Northern Macedonia. [ES]

197) A. RIZAKIS, Epigraphical Notes, in J.A. PAPAPOSTOLOU, Achaean Grave Stelai, Athens, 1993, p. 110-123: R. discusses a recently found grave stele from Kalivia (Eleia, 2nd cent. AD) which expresses the idea that the deceased woman deserved heroic honours (p. 57 note 140 and p. 120:

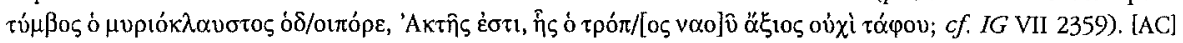

*198) N. ROBERTSON, Atbens' Festival of the New Wine, in HSCPb, 95 (1993), p. 197-250: $R$. attempts to put the fragmentary and often ambiguous evidence concerning the Athenian Anthesteria in order and to reconstruct the sequence of the rituals on the three days of the festival. On the first day the wine was distributed from the producers to the customers; on the second day, after the drinking in the household, the sacrifice of a he-goat and libations in the sanctuary of Dionysos at Limnai took place; the rituals of the third day differed between country and town. According to R.'s interpretation, the dead, which some sources associate with the day called Chytroi, were entirely absent from the Anthesteria. $[\mathrm{AC}]$

199) L.E. ROLLER, Attis on Greek Votive Monuments: Greek God or Pbrygian?, in Hesperia, 63 (1994), p. 245-262: R. examines the origin of the representations of the Phrygian god Attis in Greek art and his reception by the Greeks. The earliest representation of Attis is found on a votive stele

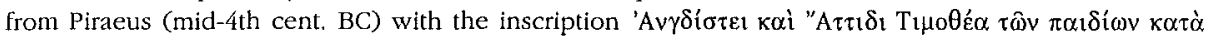
$\pi \rho o ́ \sigma \tau \alpha \gamma \mu \alpha$ (CCCA II, p. 93). Attis is defined here as the companion of the Phrygian mother goddess, protector of children, who is invoked here by the name she bore in Phrygia (Agdistis, not Meter or Kybele). This definition is consistent with the epigraphic testimonia for the cult of Attis in Piraeus, where by the 3rd cent. BC Attis had become an integral part of the cult of Meter and had his own festival, Attideia (CCCA II, $\mathrm{n}^{\text {os }} 262,263$ I, 265). Attis became an accepted figure in Greek religion in connection with the cult of the Great Mother and was widely represented. Originally, however, in the context of the Phrygian cult, Attis was the Great Mother's principal religious official. The use of the word 'Attis' as the title of an official serving in the cult of the Great Mother is also known in Greece; an inscription of the 1st cent. BC from Athens, concerning the cult of Agdistis at Rhamnous (CCCA II, $\mathrm{n}^{\circ} 245$ ) refers to one of the principal attendants of the cult using the title of $\alpha \delta \alpha \dot{\alpha} \mu \alpha \varsigma_{\varsigma}$, a variant of Attis (HESYCH., s.v. $\dot{\alpha} \delta \alpha \mu v \varepsilon i v$ ). Since in Phrygia, where Attis originally had no iconography, his iconography is a Hellenic creation. Attis' iconography was modeled after that of other Oriental figures represented in Greek art, and enabled the Greeks to worship Attis in conjunction with Meter. [ES]

200) V.J. Rosivach, The System of Public Sacrifice in Fourtb-Century Athens, Atlanta, 1994: R. examines the economic and social aspects of public sacrifice in Athens. He points out that there were two separate but related systems, one serving the needs of the polis and the other serving the needs of the multiple political units below the polis-level. The latter system is better documented, e.g., the raising of funds for sacrifice through the leasing of property dedicated to the preservance of cult activities. Within the sub-polis system the principal sacrificial animals were sheep and goats. These animals had not been raised to be sold in the open market for their meat, since in the subpolis units there was no meat-market independent of the sacrificial system. The polis system spon-

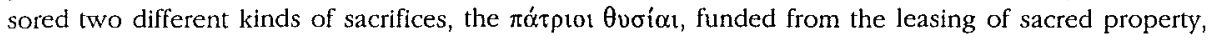

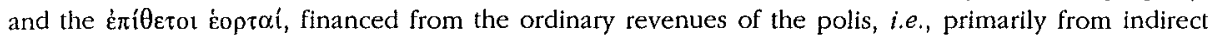
taxation. The main sacrificial animals at the patrioi thysiai were sheep and goats, whose meat was distributed to limited groups; on the contrary, sheep and goats were not sacrificed at the epithetoi heortai; goats were sacrificed only at the festival of Athena Agrotera. The sacrificial animals at the epithetoi heortai were oxen, whose meat was distributed to the citizen population at large. [ES] 
201) Ch. ROUECHÉ, Performers and Partisans at Apbrodisias in the Roman and Late Roman Periods, London, 1993 [BE 1993, 763]: In her excellent study on entertaiments and entertainers in Aphrodisias R. publishes several inscriptions related to the celebration of festivals and agons (new texts are marked with an asterisk). Three memorials were set up for troupes (familiae) of gladiators and wild-beast-fighters belonging to high priests of the civic emperor cult (*13,14, 15, 1st-3rd cent.

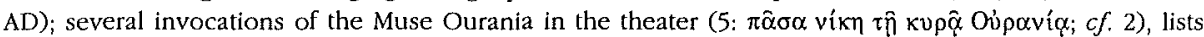
of the Muses written on columns of the theater (6.1 and 2, $6.13 \mathrm{a}-\mathrm{b})$. Philologos won a victory in Olympic games (of an unknown city) in an unknown discipline (1.4). Notice the use of mythological names by gladiators (Xanthos: $* 25$; Patroklos: $* 26$ ). Inscriptions engraved on the steps of the stadium (45.30) attest for Aphrodisias the institutions of the iepoi oikovónot (perhaps the oikonomoi of a

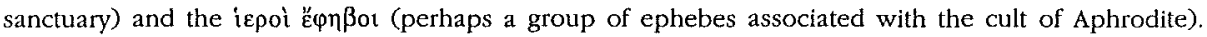
In an appendix $R$. collects the epigraphic and numismatic evidence for the celebration of agons $(\dot{\alpha} \gamma \hat{\omega} v \varepsilon \varsigma \Sigma \varepsilon \beta \alpha \sigma \tau \hat{\omega} v$, Aphrodisia Isolympia, Aphrodisia Adoneia, Attaleia Gordianeia Kapitolia, Epinikia,

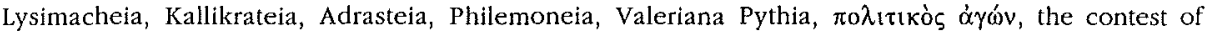
Hosidius Iulianus, the $\dot{\alpha} \gamma \hat{\nu} v \tau \hat{\omega} v \dot{\alpha} \pi$ ò $\tau \hat{\eta} \zeta \sigma v v o ́ \delta o v)$ at Aphrodisias ( $\left.n^{\text {os }} 48-65\right)$. They include honorific inscriptions for two agonothetai of the $\alpha \gamma \hat{\omega} v \varepsilon \varsigma \Sigma \varepsilon \beta \alpha \sigma \tau \hat{\omega} v(* 48,49$, 1st cent. AD), an agonothetes of the Lysimacheia $\delta \mathrm{t}^{\prime} \alpha \mathrm{i} \omega \mathrm{v} o \zeta(54,2 \mathrm{nd}$ cent. AD), an agonothetes of the Great Gordianeia Attaleia for life (56, 3rd cent. AD), for the benefactor Hosidius Iulianos who dedicated to his city an in $\mu 1 \alpha \lambda \alpha v \tau \imath \alpha \hat{\imath} \circ$

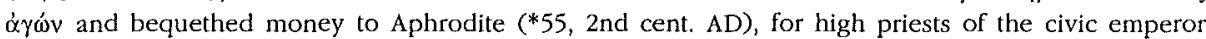
cult $(49,54,1$ st-2nd cent. AD), and neopoioi $(54,2$ nd cent. AD). Valuable information for these agons is provided by the letters of the imperial curator $M$. Ulpius Appuleius Eurykles concerning the disposition of funds set up for the financing of agons (50-51, ca. AD 180/189), two schedules of prizes for agons (52-53), a schedule for the Attaleia (*57,3rd cent. AD), and a series of decrees of Aphrodisias (58-64, ca. AD 240/250) for neighbouring cities (Keretapa, Hierapolis, Kibyra, Apollonia

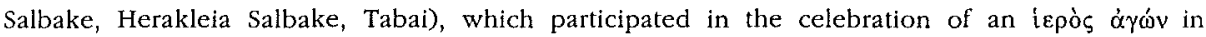

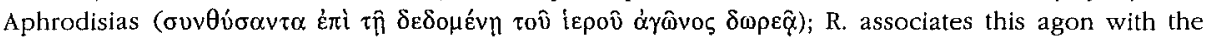
Attaleia or the Valeriana Pythia. A second appendix contains the inscriptions of victors and competitors in agons at Aphrodisias and in other cities (66-87). I single out the new texts: honorific incriptions for the kitharist Meliton (*69, early 3rd cent. AD, victor at the Aktia of Nikopolis, Damaskos, Kaisareia Stratonos, and another city, Ephesia, Pythia in Hierapolis and Laodikeia, Augusteia at Tralleis, Dia Haleia at Philadelpheia, Herakleia Kommodeia of Tyros, and the provincial agons of Kappadokia in Kaisareia, Bithynia in Nikomedeja, and Asia at Tralleias and Philadelpheia), a victor at Aktia $(* 74,3$ rd cent. AD), a boy runner who won at the third celebration of the pentaeteric Aphrodisia Philimonieia $(* 80$, late 2nd cent. AD), and a new fragment of the sarcophagus of a pankratiast attesting a victory at Herakleia $(* 71 \mathrm{e}, 2 \mathrm{nd} / 3 \mathrm{rd}$ cent.). A third appendix presents the texts relating to the activities of the associations of athletes and entertainers (88-93, no new texts). [AC]

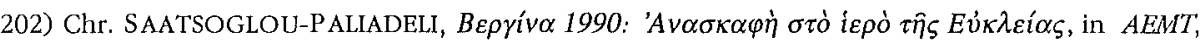
4, p. 21-34 [BE 1994, 392; 1995, 411]: A second dedication to Eukleia by Eurydike, the mother of king Philip II, was found in Eukleias' sanctuary at Vergina (ca. 350/340). A statue found in this area can be associated with this dedication. [AC]

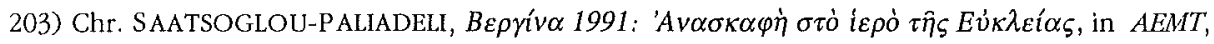
5, p. 9-21: Part of a huge marble serpent on an inscribed base was found in the area of the sanctuary of Eukleia at Vergina (2nd cent BC). The word $\theta \varepsilon \hat{\omega}[1]$ can be read on the dedicatory inscription. The statue may have been a cult statue of Zeus Meilichios. [AC]

204) S. SAHIN, Ein Ebrenmonument für Hadrian und Sabina in Rbodiapolis, in EA, 21 (1993), p. 92 [ $B E$ 1995, 563]: S. presents a recent find, an inscription written on the base of statues of Hadrian and Sabina set up by the Lykian Koinon under the high priest Opramoas (Rhodiapolis, 136 $\mathrm{AD})$. $[\mathrm{AC}]$

205) S. SAHIN, Die Inschriften von Arykanda (IGSK, 48), Bonn, 1994 [BE 1995, 80]: Most of the inscriptions included in the corpus of Arykanda are published for the first time (new texts are marked with an asterisk). Dedications to: Artemis (87), Artemis Kombike (*85, imp., the epithet, attested only in Lykia, derives from the place name Komba), Artemis Thrasenike ( 86 a, b, imp., from the place name Thersenos near Oinoanda), Helios $(* 88, * 89$, imp.), Nemesis $(* 84$, imp., attested also 
in Rhodiapolis), Traian Theos Sebastos (*17, ca. AD 117, an altar), Theos Somendeus called $\mu \varepsilon ́ \gamma(\sigma \tau o \varsigma$

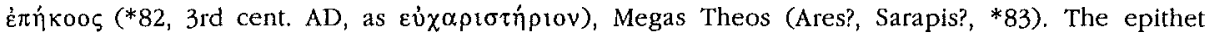
Somendeus may be associated either with Mount Somenda in the region or with Mount Solymos near Termessos, where the cult of Zeus Solymeus is attested. The fragment of a decree concerning confiscated property $(* 2$, 1 st cent. BC?) shows that the sanctuary of Artemis was the recipient of fines.

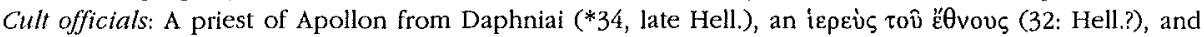

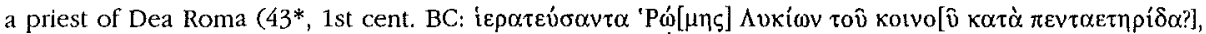
whose cult is attested from $167 \mathrm{BC}$ to the mid-3rd cent. AD. Priests of the emperor cult are attested

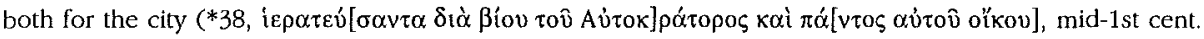

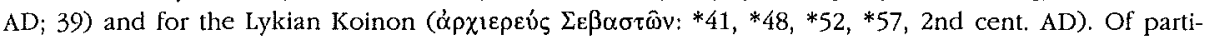
cular interest are the inscriptions mentioning the wives of high priests, who served as archiereiai

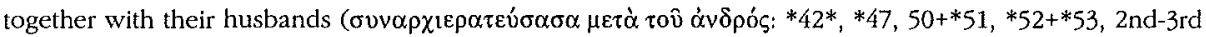
cent. AD). These honorific inscriptions show that the wives of archiereis shared with their husbands the duties of the annual priesthood of the emperor cult. They also make clear that women did not serve as high priestesses of the emperor cult in their own right, but during their husbands' term of office. [This material is of relevance for the position of archiereia in Asia; cf. supra $\mathrm{n}^{\circ} 33$, 85]. All high priests belonged to prominent families, whose members often served in this and other offices. In one case $(50+51$, p. 67) the high priestess probably served as priestess of Hera as well. Festivals: An inscription $(* 52,2$ 2nd cent. $A D)$ refers to pentaeteric festivals in connection with the emperor cult

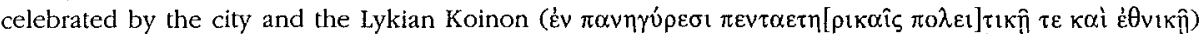

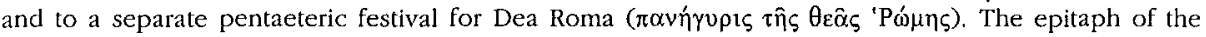
priest Hermaios (*162, 1st/2nd cent) mentions the fact that he had established agons in honor of

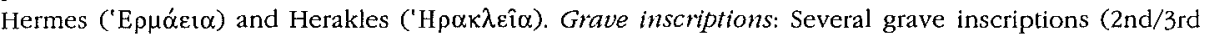
cent. AD) contain funeral imprecations and mention fines for the violation of graves (Ë $\gamma \kappa \lambda \eta \mu \alpha \tau v \mu \beta \omega$ -

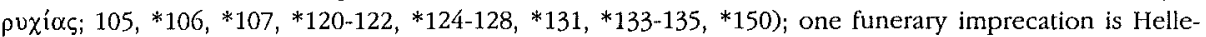

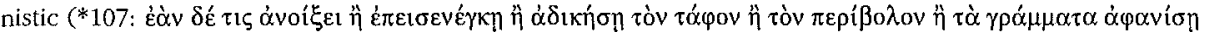

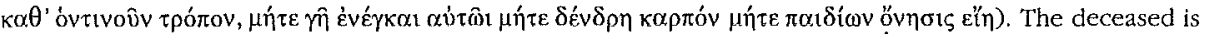

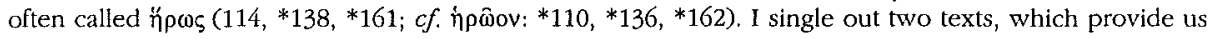
with some information about the funerary rites: Aristainete set up an altar in the heroon of her grandfather and her daughter, where she would be buried as well; she - and after her death her two

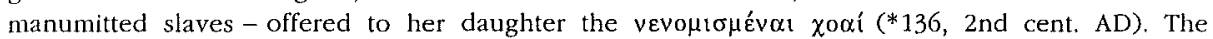
$\mu \nu \eta \mu$ ó $0 v \lambda_{0 \varsigma}$ Zosimas, i.e., a slave responsible for the grave and the performance of the funerary cult, dedicated an altar to the memory of his mistress (147, imp.). [ES]

206) S. SAHIN, Piratenüberfall auf Teos. Volksbeschluß über die Finanzienung der Erpressungsgelder, in $E A, 23$ (1994), p. 1-36: Ed. pr. of a decree of Teos concerning the collection of ransom demanded by Cretan (?) pirates for the release of captives (second half of the 3rd cent. BC). This decree mentions the festivals of Dionysia (1. 9, 32, 61) and Thesmophoria (1. 61). This inscription is the earliest attestation of the Dionysia at Teos. It is conceivable that the Teans declared the asylia of their city in the late 3 rd cent. because of the events described in this decree (or similar attacks). [ES]

207) F. SALVIAT, Timodamos et son gaulos. Oracles et marchands à Dodone, in L'Tlyrie, p. 61-64 [BE 1993, 346]: S. offers a restoration and interpretation of an oracular question addressed by a merchant at Dodona ( $P A A H, 1968$, p. 42-59, 4th cent. BC): Side A: "O Zeus, conseille Timodamos: faire commerce (sur terre et sur mer) en engageant son argent, aussi longtemps qu'il le voudra, estce là le meilleur?" Side B: "Habiter la ville; y tenir boutique; y faire commerce; et céder ta part du gaulos [designation of a ship], faire commerce, en faisant circuler des marchandises sur terre et sur mer; en vendant et en achetant". $[\mathrm{AC}]$

208) L.J. SAMONS, II, Atbenian Finance and the Treasury of Athena, in Historia, 42 (1993), p. 129-138: S. critically examines the recent view that the building of the Parthenon was not financed by the tribute of the allies [ $c f . E B G R$ 1990, 108 and 150]. He presents [inconclusive] evidence to support the opinion that at least a large part of the reserve fund of the league was not simply deposited with Athena, but was owned or controlled by the goddess. [AC] 
209) D. SAMSARIS, Les Thraces dans l'empire romain d'orient, Jannina, 1993 [BE 1995, 177]: S.'s study of the Thracians in the Eastern Roman Empire contains brief dicussions of the participation of Thracians in cult associations (p. 89-92), their worship of Greek (Dionysos, Artemis, Apollon, Zeus Hypsistos, Hera, Aphrodite, Poseidon, Pan, p. 92-95), Thracian (Totoes, Bendis, Brauro, Myndrytos, Souregethes, Vertumnus, p. 94, 337-346) and Roman gods (Iupiter, Mercurius, Fulvus, Saturnus, 95f.), the funerary cult (p. 96), the cult of the Thracian rider god by individuals and associations (p. 325-337). [AC]

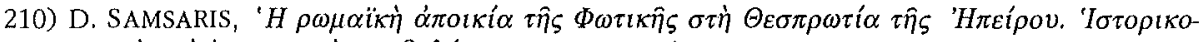

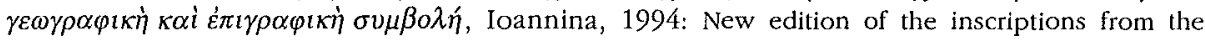
territory of the Roman colony Photike in Epirus (Thesprotia), A Latin dedication is addressed to Diana Tenacra (4, early 2 nd cent. AD); the epithet derives either from a place name or from an

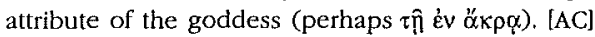

*211) J.M. SANDERS, The Dioscuri in Post-Classical Sparta, in Sculpture, p. 217-224: S. discusses the rôle of the Dioskouroi in Sparta after the revival of the agoge in $146 \mathrm{BC}$ in the light of the 'Dioskouroi reliefs' and the inscriptions. The hereditary priesthood (priest and priestess) was held by the family of the Memii; their festival included a sacrificial banquet. [AC]

212) A. SARTRE-FAURIAT, Le nymphée et les adductions d'eau à Soada-Dionysias de Syrie au. Ile siècle ap. J.-C., in Ktéma, 17 (1992) [1996], p. 133-151: An aqueduct and nymphaeum were constructed at Soada-Dionysias under Trajan (AD 105/6). Its building inscription can now be restored thanks to a rediscovered copy of the text made by William John Bankes (ca. 1816-1818). Two other texts, related to water management in this area, show that Athena (the indigenous Allat), worshipped at Arra, was regarded as protector of the water sources. [AC]

213) M.H. SAYAR, Epigraphische Forscbungen in Ostkilikien 1990. Ein Reisebericht, in Epigraphische Erforschung, p. 319-327: S. briefly present the results of a research journey in East Kilikia in 1990, during which he found 301 inscriptions. They include a dedication to Dea Roma and three altars dedicated to Zeus Theos, Zeus Olympos, and Zeus Olybreus Epekoos (Anazarbos), an epitaph with an invocation of Helios Kyrios and a funerary imprecation (Mopsouhestia), a dedication to Dionysos (Rhossos), and two letters of Sulla and Lucultus granting the right of asylia to the sanctuary of Isis and Sarapis at Mopsouhestia [see infra $\mathrm{n}^{\circ}$ 214]. [AC]

214) M.H. SAYAR - P. SIEWERT-H. TAEUBER, Asylie-Erklärungen des Sulla und des Lucullus für das Isis- und Sarapisheiligtum von Mopsubestia (Ostkilikien), in Tyche, 9 (1994), p. 113-130 [BE 1995, 601]: Ed. pr. of an inscription with two letters of Sulla and Lucullus (86 and $85 \mathrm{BC}$ ) granting the right of asylia to the temple of Isis and Sarapis at Mopsouhestia (East Kilikia) [cf. the remarks of Ph. GAUTHIER, in $B E$ 1995, 601]. From the coins of Mopsouhestia it was

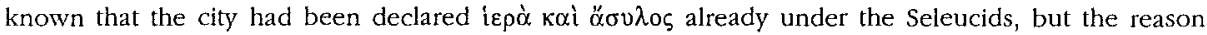
for this (i.e., this particular sanctuary) was obscure. Lucullus' letter also refers to the priest of the sanctuary, Diodoros, who generously took care of the temple and its surroundings. [ES]

215) A. SCHACHTER, The Politics of Dedication: Two Athenian Dedications at the Sanctuary of Apollo Ptoieus in Boeotia, in Accounts Lewis, p. 291-306 [BE 1995, 15]: S. discusses the political context of two archaic dedications made by prominent Athenians in the sanctuary of Apollon Ptoieus: the dedication of Alkmeonides ( $I G \mathrm{I}^{3}$ 1469, mid-6th cent.) and the dedication of Hipparchos $\left(I G \mathrm{I}^{3}\right.$ 1470, before 519). Both dedications have been interpreted in the light of Athenian politics. The dedication of Alkmeonides has been seen as an outright political statement in the context of either his purported propaganda against his opponent Peisitratos, or a conflict between Athens, Thebes, and Akraiphia; the dedication of Hipparchos is attributed to the general interest shown by the Peisistratids in oracles and as evidence for the good relations between the Peisistratids and Thebes. From an analysis of archaeological evidence concerning the temple of Apollon Ptoieus S. infers that the cult activity at Ptoion reached a peak in the period ca. 550-540/30, which coincides with the destruction of the second temple of Apollon at Delphi. S. argues that Ptoion may have profited from the partial disruption of worship at Delphi; this would explain why Alkmeonides chose this sanctuary for his dedication. The Homeric Hymn to Apollon and the pseudo-Hesiodic Aspis may have aimed at re-establishing the supremacy of Delphi by ignoring Apollon's cult a Ptoion. Hipparchos' 
dedication most likely had a political motivation; it can be taken as an indication of the friendly relations between the Peisistratids and Thebes before 519. S. also makes interesting remarks on the significance of ethnika in dedicatory inscriptions for the interpretation of cult activity in extra-urban sanctuaries. The ethnikon of a dedicant alone cannot be used as a criterion for the identification of the polis which supervised or controlled a sanctuary; on the other hand, it indicates, that the bearer of the ethnikon, and presumably his fellow-citizens, were welcome in the polis to which the sanctuary belonged. [ES]

*216) T.S. SCHEER, Mythische Vorväter. Zur Bedeutung griechischer Heroenmythen im Selbstverständnis kleinasiatischer Städte, München, 1993: S. studies the rôle of mythological traditions (Telephos in Pergamon, Mopsos in Pamphylia, the Argive heroes Perseus and Herakles in Pamphylia and Kilikia) for the collective identity and the interstate relations of cities in Asia Minor in Hellenistic and imperial times, making extensive use of the relevant literary, numismatic, and epigraphic evidence. [AC]

217) H. SCHWABL, Zum Kult des Zeus in Kleinasien, in Erforschung Kleinasiens, p. 329-338 [BE 1994, 485]: S. summarizes the contribution of new epigraphic finds to our knowledge of the cult of Zeus in Asia Minor, focusing particularly on Zeus' association with local gods (esp. Zeus Kerdylas, Kersoullos, Labraundos, Olybreus, and Panamaros). S. discusses the inscriptions relating to the sanctuary and oracle of Zeus Kersoullos, who should not be regarded as a vegetation god. He offers a new interpretation of the epigram of Gauros found in this sanctuary (I.Hadrianeia 24) [EBGR 1987, 104]. The text should be understood as follows: "I, Gauros, have received the undeceiving words of the prophetes and have represented (Кغ́ле́ $\gamma p \alpha \psi \alpha$ ) the victory of Caesar and the fights of the gods ( $\kappa \ddot{\alpha}[\theta] \lambda$ ouৎ $\theta \varepsilon \hat{\omega} v$ ), from whom I have received everything, from the beginning to the end, due to my

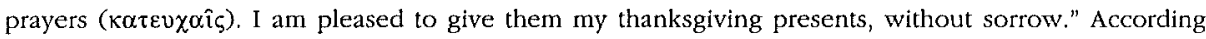
to this interpretation, Zeus was the only occupant of the oracle; Gauros was not a scribe of the oracle, but dedicated a painting which represented victories of an emperor and of the gods. [AC]

218) A.-V. SCHWEYER, Essai de définition des $\chi \hat{\omega} p \alpha \imath$ de Telmessos el de Myra, in LykienSymposion, vol. 2, p. 39-42: S. gives a new edition of the inscription on a sarcophagus (near Myra, 1st cent. BC/AD; R.M. HARRISON, in $A S, 29,1979, \mathrm{p} .205$ ), which provides for the payment of a fine to

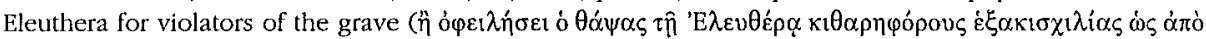

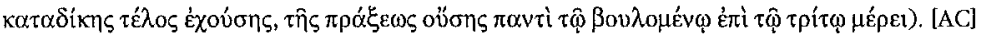

219) M. SEGRE, Iscrizioni di Cos, edited by D. PEPAS-DELmousou and M.A. RIZZA, Rome, 1993 [BE 1994, 48, 450; 1995, 448]: The two volumes (texts and plates) contain the inscriptions of Kos which S. studied in 1934-1938. S.'s death in Auschwitz (1944) left his catalogue unedited. Most texts (marked with an asterisk) are published here for the first time, with critical apparatus and very brief commentaries (if any). The editors follow S.'s (confusing) arrangement of the texts and their division into two groups (public documents: ED; dedications: EV). It is understandable that they did not alter S.'s readings and restorations and did not add any commentaries, but it is very unfortunate they do not indicate later editions of these texts (especially in $L S C G$ ), often omit cross-references to texts which belong together, and (most regretable) did not take pains to compile indices, without which S.'s valuable work is almost impossible to use. Because of these deficiencies and in view of the great importance of the new texts (among them 28 new leges sacrae), the presentation of the new texts here is slightly more detailed, including concordances with $L S C G$, a summary of the content of the texts, and in some cases an elementary commentary. The presentation is predeced by a synopsis of the leges sacrae (if not otherwise stated, all dates are $\mathrm{BC}$ ):

a. Leges sacrae conceming the sale of priesthoods: ED *15 (unknown deity, early 3rd cent.); ED $*_{2}$ = (in part) LSCG 162 (Asklepios, Hygieia, Epione, ca. 200); ED *177 (Korybantes, late 3rd cent); ED *216 (Dionysos Thyllophoros, 3rd cent.; for a later regulation about the same priesthood see LSCG 166, 2nd/1st cent.); ED *178 (Aphrodite Pandemos, late 3rd cent.); ED $* 237$ (unknown deity, 3rd cent.); ${ }^{*}$ ED 261 (unknown deity, 3rd cent.); ED *262 (unknown deity, 3rd cent.); ED $144=$ LSCG 160 (Nemesis and Adrasteia, 2nd cent.?); ED $62=$ LSCG 161 (Nemesis and Adrasteia, 2nd cent. BC?); ED *145 (Hermes Enagonios, early 2nd cent); ED *3 (unknown deity, early 2nd cent); ED *182 (king Eumenes II, 2nd cent. BC); ED *238 (unknown deity, 2nd cent); ED $58=$ LSCG 164 (unknown deity, 2nd cent.); ED *109 (unknown deity, 2nd cent.); ED *32 (unknown deity, 2nd/1st cent.); ED *165 
(unknown deity, 1st cent.); ED *180 (Herakles Kallinikos, 1st cent.); ED *215 (Zeus Alseios, 1st cent.); *ED 236 (Artemis?, 1st cent.).

b. Cult regulations, calendars, foundations: $\mathrm{ED} 241=L S C G 151 \mathrm{~B}, \mathrm{ED} 140=L S C G 151 \mathrm{C}$ (sacrificial calendar, 4th cent.); ED $55=$ LSCG 156 A $15-33$ and B 15-34 (cult of Zeus Polieus, the Twelve Gods, and Apollon Delios, 4th/3rd cent.); ED *211 (cathartic law?, early 3rd cent.); *ED 164 (sacrificial regulation, 3rd cent.); ED *16 (agon Hermaia, 3rd/2nd cent); ED *25 (festival of Artemis, 2nd cent.); ED $45=L S C G 165$ (festival calendar of the gymnasium, 2nd cent.); ED 186 (sacrificial calendar, 2nd cent.); ED $89=$ LSCG 163 (cult of Nike, 2nd/1st cent.).

c. Foundations: ED $149=$ LSCG 177 (Diomedon's endowment for the cult of Herakles Diomedonteios, ca. 300); ED 82 (foundation of Pythokles for the cult of Zeus Soter and Athena Soteira, 3rd/2nd cent.); ED *219 (endowment, 3rd/2nd cent.); *ED 146 (endowment of Phanomachos for the festival of Zeus and the Demos, 2nd cent.); ED 86 (funerary foundation, 2nd cent.); ED *257 (funerary foundation); *ED 263 (funerary foundation, imp.).

d. Regulations concerning sanctuaries: ED $181=L S C G 150$ B 12-20 (the protection of the sacred grove of the Asklepieion, 4th cent.); ED $92=$ LSCG 155 (the thesauros of a sanctuary, 3rd cent.); ED 53 (unknown sanctuary, 4th cent.); ED *60+112 (unknown sanctuary, ca. 200); ED *239 (decree about the temple of Aphrodite Pandemos, 2nd cent.)

a. Leges sacrae concerning the sale of priesthoods. New fragments of the lex sacra concerning the purchace of the priesthood of Asklepios, Hygieia, and Epione (ED *2=LSCG 162, ca. 200 BC) permit a better restoration of the text. The reverse (published here for the first time) authorizes the architect to make proposals for the purchace of equipment for the sanctuary in accordance with

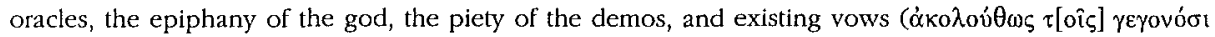

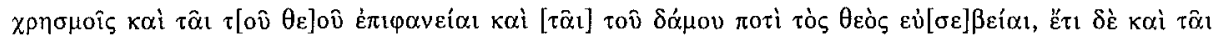

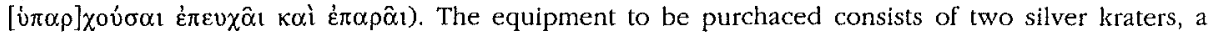
kline made of silver or ivory, and a spread on the couch ( $\sigma \tau \rho \omega \mu v \alpha$ ) prepared for the theoxenia of the god.

The most important among the new leges sacrae is the diagraphe prepared by a commission of three elected citizens about the sale of the priesthood of Hermes Enagonios (ED *145, early 2 nd cent.) [cf. S.M. SHERWIN-WHITE, Ancient Cos, Göttingen, 1978, p. 197, 203, 313]. The priest served for

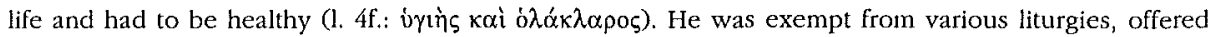
libations, was given prohedria during the agons, received the skin and one leg of the animals sacrificed to Hermes (1. 5-12), attended the procession on the occasion of sacrifices offered to Hermes, and crowned the victors of agons (1. 74-77). The text contains detailed provisions about the offering of sacrifices to Hermes by various officials (1. 12-80), stating the occasion and the minimum price of the sacrificial animal. These events, which give an insight into the education of the Koan youth in the local gymnasium find close parallels in the law from Beroia (supra $n^{\circ} 87$ ); for a discussion of the torch-races mentioned in this inscription and in the lex sacra concerning the priesthood of Zeus Alseios (infra, ED *215) see Ph. GAUTHIER, Du nouveaux sur les courses aux flambeaux d'après deux inscriptions de Kos, in RPb, 69 (1995), p. 576-585; cf. BE 1995, 448. I summarize these events in the following table:

\begin{tabular}{|c|c|c|c|}
\hline Official & Occasion & Date & $\begin{array}{c}\text { Animal } \\
\text { Minimum price }\end{array}$ \\
\hline $\begin{array}{l}\text { 1. monarchos and } \\
\text { hieropoioi }\end{array}$ & monthly sacrifice & $\begin{array}{l}\text { 2nd Hyakinthios, } 10 \text { th } \\
\text { Alseios, and } 4 \text { th day of } \\
\text { all the other months }\end{array}$ & male sheep, $30 \mathrm{dr}$ \\
\hline 2. agonothetes & 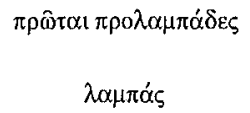 & $\begin{array}{c}\text { 10th Delios, } 16 \text { th } \\
\text { Delios, 20th Delios } \\
\text { 10th Alseios }\end{array}$ & $\begin{array}{l}\text { full-grown, } 20 \mathrm{dr} \text {. } \\
\text { full-grown, } 20 \mathrm{dr} \text {. }\end{array}$ \\
\hline
\end{tabular}




\begin{tabular}{|c|c|c|c|}
\hline 3. each lampadarchos & 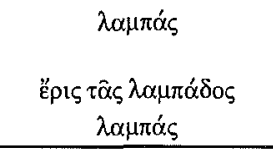 & $\begin{array}{c}\text { 25th Dalios, 1st Alseios, } \\
\text { 6th Alseios } \\
\text { 4th Alseios } \\
\text { 10th Alseios } \\
\end{array}$ & $\begin{array}{l}\text { full-grown, } 20 \mathrm{dr} \text {. } \\
\qquad \begin{array}{l}40 \mathrm{dr} . \\
40 \mathrm{dr}\end{array}\end{array}$ \\
\hline $\begin{array}{l}\text { 4. victorious } \\
\text { lampadarchos in } \\
\text { competitions of } \\
\text { عن่ } \xi \xi^{\prime} \alpha \text { and } \delta \text { pó } \mu \text { os } \\
\end{array}$ & $\begin{array}{c}\kappa \alpha \tau \dot{\alpha} \tau \dot{\alpha} v \alpha u ̈ \rho t o v \\
\tau \hat{\alpha} \varsigma \lambda \alpha \mu \pi \alpha \dot{\delta} \delta \circ \varsigma\end{array}$ & & full-grown, $30 \mathrm{dr}$. \\
\hline 5. gymnasiarchos & 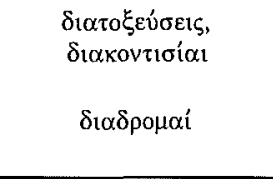 & $\begin{array}{c}\text { Theudaisios, Kaphisios, } \\
\text { Gerastios, Agrianios, } \\
\text { Panamos, and Alseios } \\
\text { Artamitios and Agrianios } \\
\text { 10th Alseios }\end{array}$ & $\begin{array}{l}25 \mathrm{dr} . \\
10 \mathrm{dr} \\
20 \mathrm{dr}\end{array}$ \\
\hline 6. paidonomos & 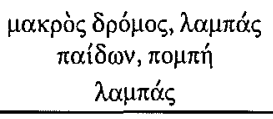 & $\begin{array}{l}\text { 2nd Hyakinthios } \\
\text { 10th Alseios }\end{array}$ & $\begin{array}{c}\text { full-grown, } 20 \mathrm{dr} \text {. } \\
30 \mathrm{dr} \text {. }\end{array}$ \\
\hline 7. strategoi & & $\begin{array}{l}\text { Artamitios } \\
\text { Panamos } \\
\text { Karneios } \\
\text { Kaphisios } \\
\end{array}$ & $\begin{array}{l}40 \mathrm{dr} \\
40 \mathrm{dr} \\
40 \mathrm{dr} \\
40 \mathrm{dr}\end{array}$ \\
\hline 8. paidotribai & after their dokimasia & 2nd Hyakinthios & $30 \mathrm{dr}$. \\
\hline
\end{tabular}

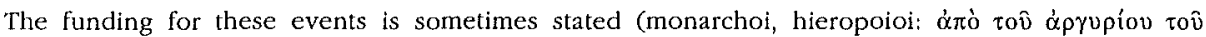

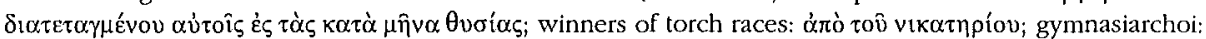

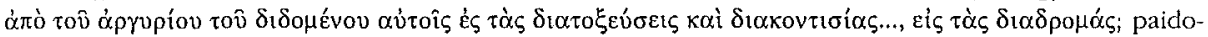

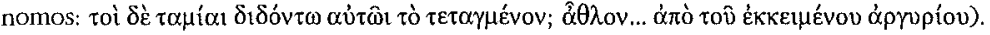

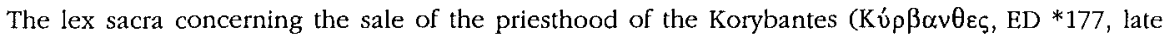
3rd cent. BC) requires for the priest, who served for life [on 1.6 one should restore [żлi ßíov] rather than [ $\delta$ iò $\beta$ Biov]; $c f$. ED *178 l. 7f.], to be healthy and older than 20 . He was exempt from various liturgies, offered libations and was given prohedria at the $\chi 0$ ptкoi $\alpha \gamma \hat{\omega} v \varepsilon \varsigma$, had a share on the meat of animals sacrificed, and had to place offerings on the trapeza on the occasion of sacrifices. On 1.12

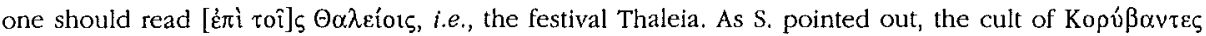
$\Theta \alpha$ ' $\lambda \mathrm{E} 101$ is attested at Erythrai (LSAM $25 \mathrm{l}$. 108, with the commentary of F. SOKOLOWSKI on this epithet).

The lex sacra concerning the sale of the prieshood of Aphrodite Pandemos (ED *178, late 3rd cent.; $c f$. Ph. GAUTHIER, in $B E 1995,448$ ) states the usual requirements for the priestess, provides for sacrifices which had to be offered to the goddess (by all women within a year after their marriage

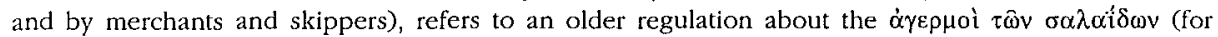
this enigmatic word $c f . S G D I$ 3707: $\sigma \alpha \lambda \alpha i \delta 1 \alpha$ ), and takes measures for repairs in the sanctuaries of Aphrodite Pandemos and Aphrodite Pontia; the Onoovpós was to be opened every year in the month Dalios and its content was divided between the priestess and the goddes. The text also contains a list of women who contributed money for the construction of a peribolos in the sanctuary. The priestess Lykaonis is the daughter of Phanomachos, who dedicated land and houses for the funding of a festival of Zeus and the Demos (infra, ED *146).

Another lex sacra (ED *180, 1st cent. BC; cf. Ph. GAUTHIER, in $B E 1995$, 448) concerns the

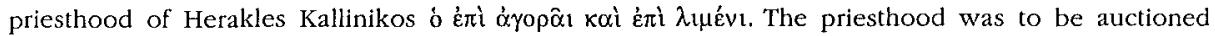
under the prostatai, after a sacrifice for the welfare of the population on the 1st day of Panamos. The priest served for life, had to be healthy and older than 10, was exempt from various liturgies,

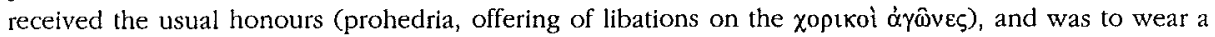

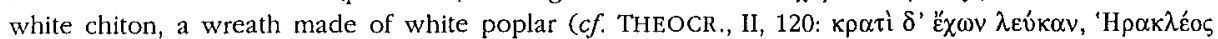

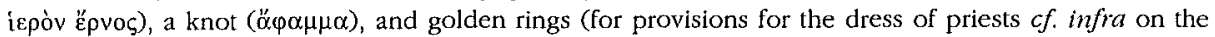
priest of Zeus Alseios and see A. CHANIOTIS, Sich selbst feiern! Die städtischen Feste des Hellenis- 
mus im Spannungsfeld zwischen Religion und Politik, in P. ZANKER - M. WÖRRLE (eds), Stadtbild und Bürgerbild im Hellenismus, München, 1995, p. 158). The text provides for the offering of sacrifices on various occasions and for their funding.

The lex sacra concerning the priesthood of Zeus Alseios (ED*215, 1st cent.) is similar in content. The priest had to be older than 8. Besides the usual privileges (prohedria, offering of libations at the Dionysia, exemption from certain liturgies), he extracted revenues from the temenos and crowned the victors at the various competitions of the Alseia. He wore a purple chiton, gold ornaments

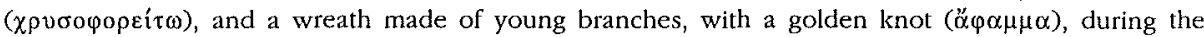
agons. The temenos of Zeus Alseios was equiped with a stadium, a nakoreion, and a house for the priest (oiki $\alpha$ ). Space should be reserved for the erection of tents ( $\sigma \kappa \alpha v o \pi \alpha \gamma i \alpha 1$ ) by the kanephoroi, for $\alpha \gamma \varepsilon p \mu o i$, and for sacrifices offered to a goddess (obviously Athena Alseia). On the 10th of Alseios sacrifices were offered by the monarchos and the hieropoioi ( $1 \mathrm{ox}, 1$ sheep), by each lampadarchos ( 1 pig), by the agonothetes ( 1 pig), and by each deme ( 1 sheep). On the 2 nd of Hyakinthios (the day of an agon?) the strategoi lead a procession together with the priest, the agonothetes, the gymnasiarchos, and the hypogymnasiarchos; the procession was attended by the armed youth; sacrifices were offered by the strategoi, the gymnasiarchos, and the agonothetes ( 1 ox each).

The sale of the priesthood of Dionysos Thyllophoros is regulated by another lex sacra (ED *216, late 3rd cent. $\mathrm{BC}$ ), whose content is similar to that of a later diagraphe on the same subject (LSCG $166,2 \mathrm{nd} / 1$ st cent.); the only substantial difference is the age of the priestess (older than 12 in the earlier text, older than 10 in the later). The passage about the share of the priestess on parts of the sacrificial animals is better preserved in the text published here, thus permitting the restoration of LSCG 166 I. 61f. According to an amendment (B 19-24) the priestess should contribute to the repairs in the sanctuary of Antigonos, probably Antigonos Doson (SHERWIN-WHITE, o.c., p. 115; cf. LSCG 166 1. 69 and ED *85 1. 9: 'Avtróveiov).

From another lex sacra concerning the priesthood of an unknown deity, perhaps Artemis, (*ED 236, 1st cent. BC) only the regulations about the sacrifices (1. 1-5) and the duties of the priestess (1. 5-12) are preserved. The priestess was responsible for the organization of an $\alpha \gamma \varepsilon \rho \mu$ ó $s$ on the 1st of Artemisios, on the same conditions as those established for the $\alpha \gamma \varepsilon \rho \mu$ ó for Artemis Pergaia. She

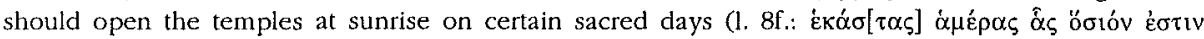

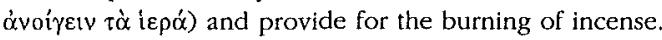

A lex sacra (ED *85, 2nd cent.) concerns the sale of the priesthood of an unknown deity (1. 7: tóv

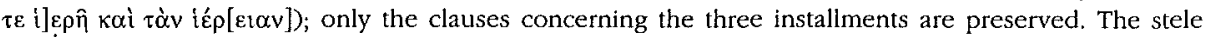
with the text was to be set up in the Antigoneion, i.e., the sanctuary of Antogonos Doson (see supra on the priesthood of Dionysos Thyllophoros).

Two fragments of another lex sacra $(\mathrm{ED} * 3$, early 2 nd cent. $\mathrm{BC})$, which concern sacrifices, are probably part of a diagraphe on the sale of a priesthood as can be inferred from the words $\delta 1 \alpha \gamma \rho \alpha \varphi n$

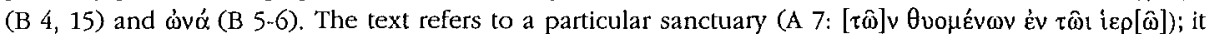
defines the perquisites ( $\gamma \varepsilon \dot{p} \eta$ : A 3, 8) of a priestess ( $\alpha$ lépet $\alpha$ : A 2, 4, B 7, 16) with regard to the sacrifices offered there (A 4-16) and mentions her duty to place the offerings on the trapeza (A 9). The festival Dipanamia is mentioned twice (A 2, B 11). The word ['A $p \rho o$ ] íoiov (B 7) probably refers to a sanctuary of Aphrodite and not to a tax on prostitutes (on the cult of Aphrodite on Kos see V. PIRENNE-DELFORGE, L'Apbrodite grecque, Liège, 1994, p. 117, 120, 385, 434; on the tax of courtisans: ibid., p. 117, 120).

A fragmentary diagraphe (ED $* 32,2$ nd/1st cent.) is probably of similar content. It concerns sacri-

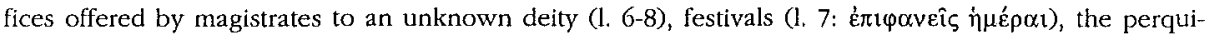
sites of the priest (1. 8), the possibility of a relocation of the sanctuary (1. 12?), and the decoration of statues in the bouleuterion (1. 15).

The preserved passages of two already published leges sacrae concerning the sale of the priesthood of Adrastela and Nemesis (ED $144=L S C G$ 160, 2nd cent?; ED $62=$ LSCG 161, 2nd cent.?) deal with sacrifices and the perquisites of the priest. Another lex sacra regulates the sale of an unknown priesthood (ED*109, 2nd cent); the text mentions a sacrifice and a prayer; the priest was to be older than ten; he was exempt from various liturgies and had a share on the sacrificial animals.

The texts concerning the priesthoods of king Eumenes II (ED *182, 2nd cent.) and of unknown deities (ED *15,*165,*237, *238,*262; ED $58=$ LSCG $164,3 \mathrm{rd} / 2$ nd cent.) are very badly preserved; ED 
* 15 (early 3rd cent.) contains clauses about the perquisites of the priest and his duty to place the offerings on the trapeza. ED $58=$ LSCG 164) is probably part of a lex sacra about the sale of a priesthood; the preserved passage deals with sacrifices, the duties and perquisites of the priest, and the thesauros of the sanctuary. It is not clear whether *ED 261 (3rd cent.) also concerns a sanctuary or the sale of a priesthood.

b. Cult regulations, calendars: A few texts were already known, but in several cases S. gives different readings or restorations. Two fragments belong to an already published sacrificial calendar (ED $241=\operatorname{LSCG} 151 \mathrm{~B}$; ED $140=L S C G 151 \mathrm{C}$, 4th cent.). S.'s restorations of the festival calendar of the gymnasium (ED $45=$ LSCG 165, 2nd cent.) differ in two points. According to $\mathrm{S}$. the sacrifice to Zeus and Athena (A 1) was offered in Gerastios ([K $\alpha \rho v \varepsilon]$ iov Herzog, $[\Delta \alpha \lambda]$ íov] Rayet); a procession for a

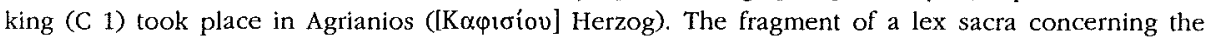
cult of Zeus Polieus, the Twelve Gods, and Apollon Delios (ED 55, 4th/3rd cent.) is now fully published with additional fragments (LSCG 156; ED $55=\angle S C G 156 \mathrm{~A} 15-33$ and B 15-34). S.'s restorations

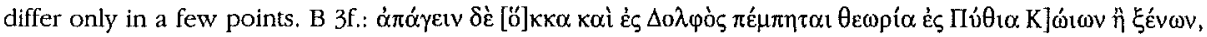

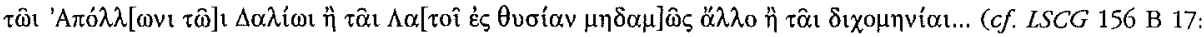

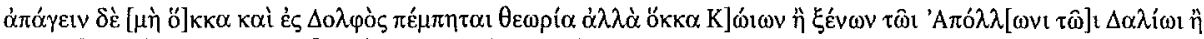

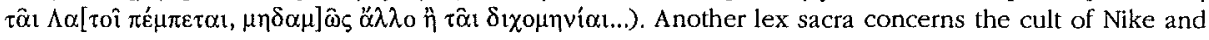
the procession organized to honour her (ED $89=L S C G 163,2 \mathrm{nd} / 1$ st cent.).

The fragments of a lex sacra concerning the Hermaia (ED *16, $3 \mathrm{rd} / 2$ nd cent.; cf. supra on the priesthood of Hermes Enagonios) provides for sacrificial animals to be contributed by the gymnasiarchos, the hypogymnasiarchos, and members of the gymnasium.

A lex sacra (ED *25, 2nd cent.) concerns a festival of Artemis. The prostatai, together with the monarchos and the hieropoioi, were to lead a procession from the prytaneion and to sacrifice to

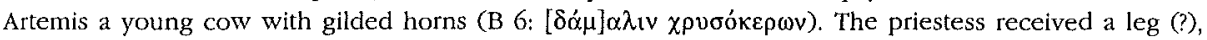

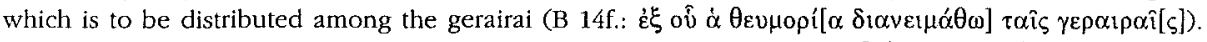
After (?) the sacrifice a torchlight procession took place (B 4, 10f.: $\lambda \alpha \mu \pi \alpha \delta \varepsilon i \alpha$ ). An i $\pi$ tépeı $\alpha$ is mentioned on A 7; cf. the íplépel $\alpha$ appointed by the priestess of Dionysos Phyllophoros (LSCG 166 l. 23f.).

From another lex sacra (*ED 164, 3rd cent.) only the sacrifice of a she-goat can be inferred; the

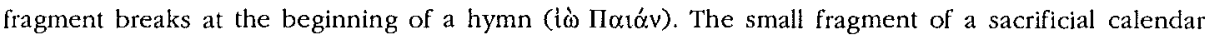
(ED 186, 2nd cent.) mentions Hekate, the Twelve Gods, the Nymphs, and a goddes with the epithet Teleia (Hera?), and the use of wine.

Two small fragments (ED *211, early 3rd cent.) seem to be part of a cathartic law of similar content to LSCG 154 (early 3rd cent.). The monarchos, the hieropoioi, and the heralds are mentioned in the first lines (A 1-2; cf. LSCG 154 A 33); the tamiai were to provide with funds, perhaps for the setting up of an inscription (A 4; $c f . L S C G 154 \mathrm{~A} \mathrm{12)}$; the rest of the text is concerned with purifica-

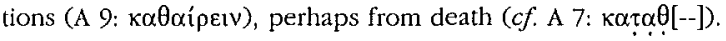

c. Foundations: The lex sacra concerning the foundation of Pythokles for the cult of Zeus Soter and Athena Soteira (ED 82, 3rd/2nd cent.) was published (W.R. PATON - E.L. HICKS, The Inscriptions of Cos, Oxfod, 1891, $\mathrm{n}^{\circ} 34 ;$; $f$. LGS II 131), but S.'s text offers numerous restorations. The festival Pythokleia is also mentioned in $\mathrm{EV} * 1341$. 5. A lex sacra deals with the festival of Zeus and the Demos established after the endowment of Phanomachos (*ED 146, 2nd cent.), who dedicated ( $\dot{\alpha} \vee \varepsilon \rho \rho \hat{i})$ plots of land and houses to Zeus and the Demos (A). The procession in the month Gerastios (B) was lead by the priest and the prostatai from the prytaneion to the sanctuary (of Zeus?) and was attended by the ephebes and by paides who played the kithara. If the reading in lines B $12 f$. is correct, a phallophoria took place (tò $\varphi \propto[\lambda] / \lambda$ ó $\varsigma$ ). The sanctuary was still under construction (C 1f.:

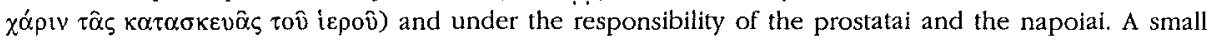

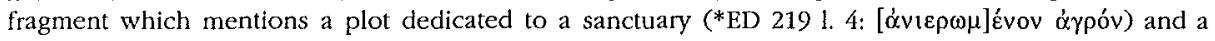
sacrifice (1. 3f.) is probably also part of an endowment. Diomedon's endowment for the cult of Herakles Diomedonteios was already known (ED $149=L S C G 177$, ca. 300).

Another lex sacra concerns the endowment of bereft parents in a gymnasium; on the é $\pi \omega v v \mu \circ$ $\dot{\eta} \mu \varepsilon \dot{\varepsilon} \rho \alpha$ of their son sacrifices were offered to Hermes and an agon took place (ED 86, 2nd cent.). Another fragmentary text $(\mathrm{ED} * 257$, imp.) contains the endowment of an individual for the celebra-

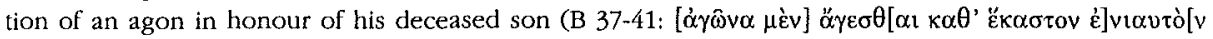

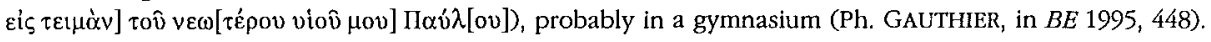


S. recognized that $* \mathrm{ED} 263$ (imp.) refers to an endowment for the organization of an agon on the

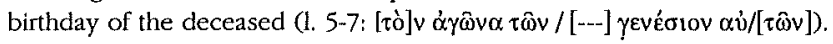

d. Regulations concerning sanctuaries: A fragment of the law concerning the protection of the sacred grove of the Asklepieion was already published (ED $181=L S C G 150 \mathrm{~B} 12-20$ ), as was the fragment of the lex sacra dealing with the thesauros of a sanctuary, perhaps the Asklepieion (ED $92=$ LSCG 155, 3rd cent.), and a lex sacra concerning a sanctuary and threatening violators with a curse ('̇ $\pi \alpha \rho \alpha$ ) and punishment (ED 53, 4th cent.). From the decree concerning the temple of Aphrodite Pandemos (ED *239, 2nd cent.) only the beginning is preserved. A fragmentary text (ED *60+112, ca. 200) deals with the finances of a sanctuary and mentions a priest and a neokoros.

In addition to the leges sacrae presented above the volume contains many inscriptions which illuminate different aspects of religion in Hell. and Roman Kos.

Dedications, contributions: A proscription about the use of water (ED *10, 1st cent. BC/AD)

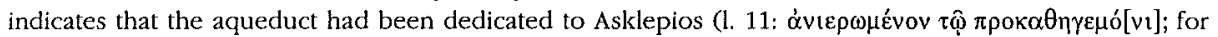

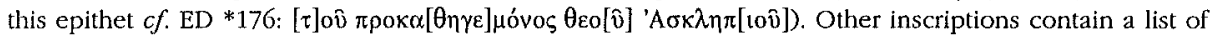

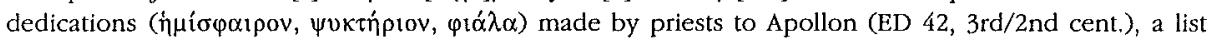
of women who contributed money to a sanctuary of Demeter (ED *14, 3rd/2nd cent.; $c f$. Ph. GAUTHIER, in $B E 1995,448$ ), and a list of donors to an unknown sanctuary (ED $47=$ PATON-HICKS, o.c., $\mathrm{n}^{\circ} 12$, 3rd cent.). Other dedications are addressed to Aphrodite and Homonoia (EV $* 2$, $3 \mathrm{rd}$

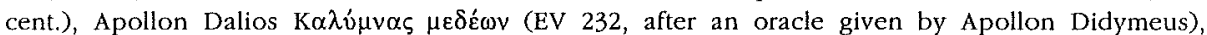
Apollon Didymeus Soter and Apollon Didymeus (EV 14,*192, by the crews of a warship), Apollon Karneios (?, EV *195, various buildings, by his priest), Artemis (EV 99), Artemis Pergaia (EV *179, a temple), Asklepios (EV*28), Athena and the other gods (EV 80), Athena Phatria (EV*334), Demeter (EV 4, 270, 271), Eileithyia (EV *198), Eirene (EV *227, by agoranomoi), Hermes and Herakles (EV 5 , by a victor; EV $* 12$, by a paidonomos; $* 175$, by the victors of the torch-race at the Hephaistieia),

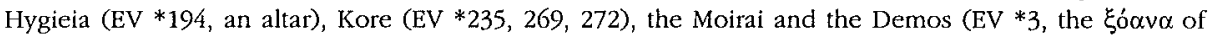
gods and the buildings of a sanctuary, by the father of a priestess), Ourios (EV*196), Podaleirios (EV *197), Poseidon Asphaleios (EV *154, by his priest), Poseidon Hippios (EV 180), Theos Hypsistos (EV *69), Theoi (EV 32,*141, *156,*157,*159,*177, 209, 211,*215,*217, *229, *345?, usually by generals), Theoi and the Demos $(\mathrm{EV} * 212)$, Theoi Soteres and Apollon Kalymnios (EV*210), Zeus Alseios and Athena Alseia (EV *1, 10,*214, 228, 1st. cent., by paidonomoi for the walfare and $\varepsilon \dot{\tau} \tau \dot{\xi} \dot{1} \alpha$ of the boys; * 178 , by the priest of the Muses; $* 196$, by the victors of a competition of $\varepsilon \dot{\varepsilon} \varepsilon \xi i \alpha ; * 372$ by the boys and their teachers; the name of Zeus Alseios should be restored on the left side of EV *228), Zeus Basileus (EV *27), Zeus Hikesios (EV 335), Zeus Hypsistos, Hera Ourania, Asklepios, Hygieia, and all the gods (EV *127, for the rescue of the city), Zeus Olympios, Sarapis, and Hera Ourania (EV 6, for the welfare of the city), Zeus Olympios, Hera Ourania, Poseidon Asphaleios, Apollon, and all the

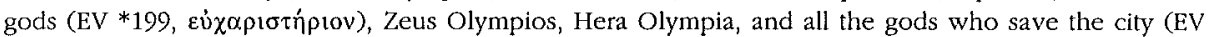

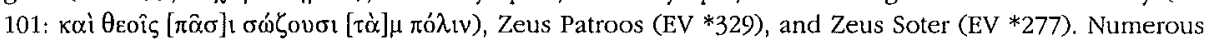
dedications are addressed to the Theoi Patrooi for the health of prominent citizens, i.e., the tyrant Nikias (*57, *74, 130,*283,*285,*291, 293,*309, 310,*312,*340 probably *295, 1st cent.), the physician of emperor Claudius C. Sertinius Xenophon (EV *22,*25,43,*46,68,*70,*83, 97, *112, *117, *119, $* 124, * 143, * 286, * 288, * 289, * 296-298,299, * 300-302, * 311, * 314-322, * 325, * 327337, * 341, * 344, * 347$, $* 365, * 366$, probably also $* 290, * 294,324)$, M. Aelius Savinianos $(* 71,84, * 86, * 88, * 281, * 282, * 287$, $* 292, * 304-308,313, * 323,336,338, * 342, * 343)$, M's Spedius Rufinus Phaidros $(81, * 303,339)$, and M. Ulpius Trajanus (EV 326, this one is also addressed to Apollon Archegetes).

The dedicated objects include statues of Aphrodite (EV*171), Dionysos (EV 102 bis, for the welfare of the emperors), Eueteria (EV 32, to the gods), and Herakles (EV *214 Ab), and a silver

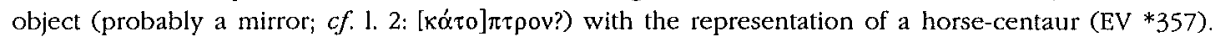
The dedicatory epigram of the paidonomos Philippos mentions that he dedicated to Zeus Alseios and Athena Alseia (called also Pallas, Tritogenes) a statue of Herakles, whom he regarded as his

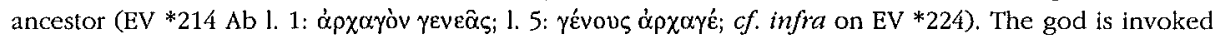

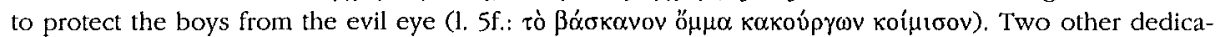
tory epigrams, which refer to a goddess (EV *184) and to a pentaeteric festival (EV *326, probably the Asklepieia) are very fragmentary. 
An altar for domestic use is inscribed on its four sides with the names of four groups of deities (EV * 18, 3rd cent.). As S. points out, the deities of side A are protectors of Kos (Apollon, Asklepios, Herakles, the Dioskouroi); side $B$ mentions deities associated with nature and with literature (Helios, Hemera, the Horai, the Charites, the Nymphs, Priapos, Pan, Hermaphroditos); the deities on side C protect the individual (Zeus Philios, the Theoi Soteres, Hermes Probakchos, Peitho, Nikeros); the deities of side D are associated with the glory of two members of the family, who probably won victories at the Nemea and the Isthmia (Zeus Nemeios, Poseidon Isthmios, Athena Nike, and Mvń $\mu \eta$

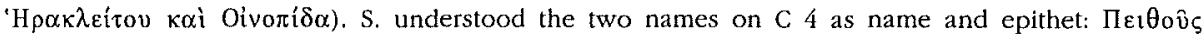

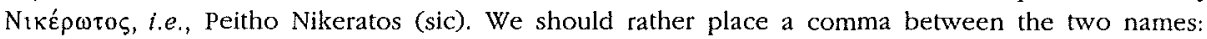

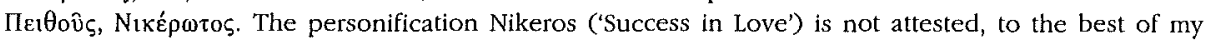
knowledge, and should be understood as the opposite of Anteros, the god who avenges slighted love or the god who struggles against Eros. An analogous assemblage of deities associated with abstract ideas (Zeus Eumenes, Hestia, Eudaimonia, Ploutos, Arete, Hygeia, Tyche Agathe, Agathos Daimon, Mneme, the Charites, and Nike) is found in the lex sacra of a private cult association at Philadelpheia (LSAM 20; $c f$. the commentary of S.C. BARTON-G.H.R. HORSLEY, A Hellenistic Cult Group and the New Testament Cburch, in JAC, 24, 1981, p. 12-14).

Some dedications are addressed to Egyptian, Roman, and Oriental deities: Isis and Sarapis (EV *16; 149, $\kappa \alpha+\alpha \grave{\alpha} \pi \rho o ́ \sigma \tau \alpha \gamma \mu \alpha)$, Sarapis, Isis, and Anoubis (EV*13, by a cult association of enatistai and dekatistai), Osiris (EV 375, by a synod of Osiristai), Minerva (EV 276), Mars Pater (EV 284), Baal and Aphrodite/Bala (EV 259 and 260, 1st cent. AD, these two texts are bilingual, Greek-Nabatean, dedications).

Festivals: Numerous texts give information about the Koan Asklepieia (ED *36, 132, *171; $c f$. ${ }^{*} 169$, *170; EV *372, 3rd cent.) and the Great Asklepieia (ED 134, 3rd cent.; cf. EV*362). A Koan decree (ED 136, 3rd cent.) refers to a theoria and sacrifice to Asklepios and the other gods sent by Ptolemy (Euergetes?). The new texts include the decree of an unknown city (ED * 38, 3rd cent.) which recognized the asylia of the Asklepieion and accepted the festival (sacrifice, truce, agon). Other festivals attested for Kos are the Dionysia (ED *8, *39,132,134,*171, 3rd-1st cent; $c f$. two lists of victors at the Dionysia: ED 52, 234, 3rd cent), Dipanamia (ED*3, 2nd cent.), Hephaistieia (EV *175), and Thaleia (related to the Korybantes, ED *177, see supra). Various agons of the youth are mentioned in the leges sacrae concerning the priesthoods of Hermes Enagonios and Zeus Alseios (supra). 'A of women are attested for the worship of Aphrodite Pandemos, Athena Alseia, and Artemis Pergaia (see supra on the priesthoods of Aphrodite, Zeus Alseios, and Artemis). The leges sacrae concerning

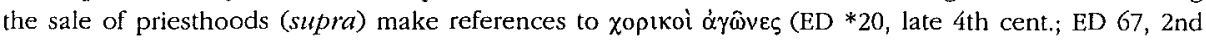
cent.). An incription records the tribal leaders ( $\alpha p \chi \varepsilon v \sigma \alpha \nu \tau \varepsilon \varsigma$ ) who offered sacrifices to the Nymphs and feasted their tribesmen (ED $81=$ PATON-HICKS, o.c., $\mathrm{n}^{\circ} 44, \mathrm{ca} .200$ ). A benefactor is honoured for donating money for sacrifices (ED 131, 2nd cent.).

Festivals of other cities are mentioned in honorific decrees of foreign cities for Koans; the honours were to be announced at the Dionysia in Samothrake (ED *28-29, 3rd cent), Chios (ED 71d, after the procession), and Iasos (ED 133, 2nd cent.), and at the Panathenaia in Athens (ED 71c). Kos sent a theoros to the Great Gods in Samothrake (ED *28 and 29, 3rd cent; cf. Ph. GAUTHIER, in $B E$ 1995, 448). The decree by which the Koans accepted the festival of Artemis Hiakynthotrophos in Knidos (ED 77, ca. 201) has been published recently (SEG 38, $812 \mathrm{~A}$; I.Knidos $220=$ EBGR 1987, 90). A few agonistic inscriptions mention athletic victories in agons of various cities (EV *42: Aktia; *53: Kapitolia; * 242: Nemea; *247: Olympic games; 203: Megala Eleusinia, Isthmia, Rhomaia in Kos, Kaisareia in Metropolis, Hekatesia in Stratonikeia, Theogamia in Nysa, Klaria in Kolophon, Archegesia in Halikarnassos, Apollonia in Mydnos; 218: Megala Panathenaia, Kaisareia in Patrai, Megala Aktia, Megala Asklepieia, Kaisareia, Kaisareia for C. Caesar, Agrippeia, and Nea Agrippeia in Kos, Rhomaia Sebasta of Asia in Pergamon, Apollonia in Myndos, Doreia in Knidos, Kaisareia in Halikarnassos, Herakleia in Iasos, Dionysia in Teos, Kaisareia in Sardeis). The places of the victories of another pleistonikes are not preserved (ED *271, imp.). The auletes Ariston (EV 234, imp.) mentions his victories at various agons (Pythia, Nemea, Isthmia, Aspis of Argos, Panathenaia) in his metrical dedication of a statue of Dionysos.

Cult officials: For the priests and priestesses of Asklepios, Hygieia, and Epione (cf. EV 226), the Korybantes, Dionysos Thyllophoros, Aphrodite Pandemos, Nemesis and Adrasteia, Hermes 
Enagonios, king Eumenes, Herakles Kallinikos, Zeus Alseios, and Artemis see supra (sale of priesthoods). For the priests of the emperor cult see infra. Other priests attested are those of Apollon (EV *134), Apollon Karneios (EV*195*219), Asklepios and Hygieia (EV 26), Askepios Kaisar (EV 206), the Muses (EV *178), Poseidon (EV*154, for life), Sebaste Rhea (EV*219), Zeus Olympios (?, EV

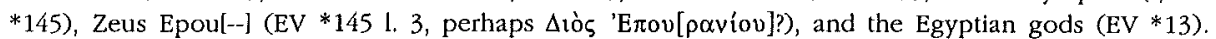
Priestesses are attested for Apollon Delios and Apollon Karneios (EV 226), Asklepios (ED *264 1. 7 :

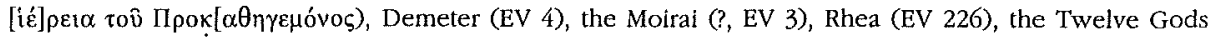
(EV 226), Zeus Polieus and Athena Polias (EV 226). Other cult officials include agonothetai (EV *15,

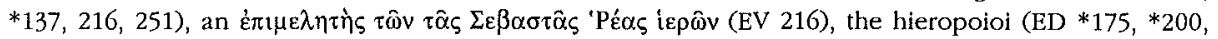
$* 211$; EV *2, 32,*220; $c f$. the hieropoioi of unknown cities: ED 71f, *93, 3rd cent.), the neopoioi (ED *185), a neokoros (EV 149), the kanephoroi (ED *216), and a female hierodoulos (EV 41). Several prominent individuals accumulated offices, as, $e . g$, Minnis who held simultaneously the priesthoods of Asklepios, Hygieia, and Epione, Rhea, the Twelve Gods, Zeus Polieus, Athena Polias, and Augustus, and had already served as priestess of Apollon Dalios and Apollon Karneios (EV 226, 1st cent. AD), an anonymous (EV *134, 1st cent. AD) who served as priest of Apollon and various emperors, and had an unknown function with regard to the cult of Hestia, and Zeus Soter and Athena Sotera (cf. on 1. 5 the name of their festival Pythokleia), or C. Stertinius Xenophon, the most famous Koan doctor

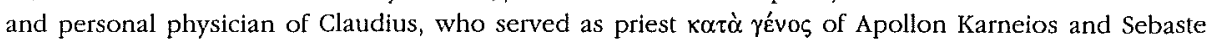
Rhea, and as priest of the emperors for life (EV *219). Priests and priestesses of unknown deities are mentioned in different contexts (priests: ED 121,*175,*192, EV *67; a priest for life: EV *79; a priestesses: $\mathrm{EV} * 3$ ).

Cult associations: An association honoured a priest and a kleidouchos (ED*102, 2nd cent.).

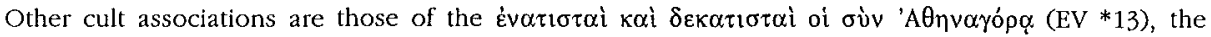

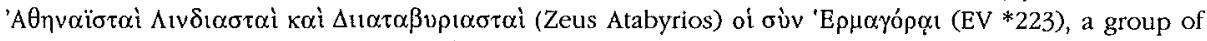
eranistai (EV *278), and the Osiristai oiv 'Ióowv (EV 375).

Royal cult: The sanctuary and the altar of Antigonos Doson (Antiogoneion) is mentioned in two texts (ED *85 1. 9; ED*216 1. B 20; cf. SHERWIN-WHITE, o.c., p. 115; LSCG 166 1. 69). A lex sacra concerns the priesthood of king Eumenes (supra). A decree concerning celebrations in honour of the Kappadokian royal couple, Ariarathes IV and Antiochis (ED 5, ca. 188/166), has already been published by F. PIEJKO ( $S E G 33,675$; $c f$. Ph. GAUTHIER, in BE 1995, 448). Of the two fragments of a decree for the establishment of the cult of Arsinoe Philadelphos in accordance with an oracle only fr. B was published (ED *61, 3rd cent.).

Emperor cult: A document refers to the deification of Iulius Caesar by the province Asia (ED

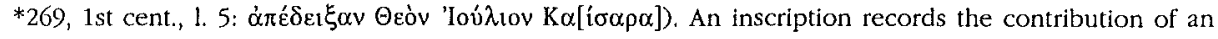
individual to the cult of Asklepios, the Emperors, and the Demos (ED 142, 1st cent. AD, 1. 1f:; [ $\tau \hat{\omega} 1$

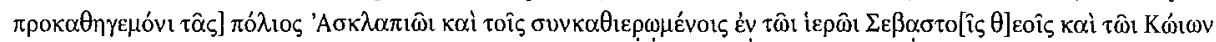
$\Delta \alpha \dot{\alpha}(\omega 1)$. A text records the purchase of the priesthood of Asklepios and Augustus (*ED 266, 1st cent. $\mathrm{AD})$. Various priesthoods are attested with regard to the emperor cult: We know of a high priest of the Sebastoi (EV 222) and Claudius, ktistes of Kos (EV*134 1. 5f.), priests of Augustus (EV *241, for life; $c f$. EV *134), Tiberius (EV*134 l. 3f.), the Sebastoi (EV*219, for life), Claudius (EV*219, for life), and Trajan (EV *214 B), and of priestesses of Augustus (EV 226, cf. EV *240), Claudius (EV *72, for life), and for a female member of the imperial family (EV 364, for life). Another priesthood was dedi-

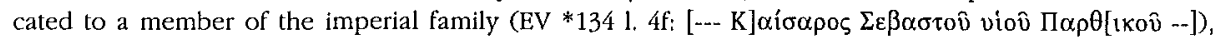
obviously not Trajan; perhaps this is reference to Caius Caesar (after his meeting with the king of the

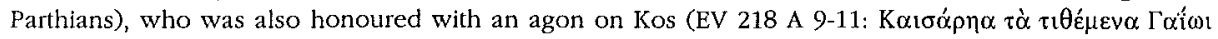

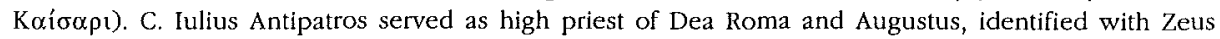
Patroos, in the province of Asia (EV *219, 1st cent. AD). Several dedications are addressed to emperors: Augustus (ED *146 block E), Augustus and the sacred Tyche (SEGRE) of the Roman people

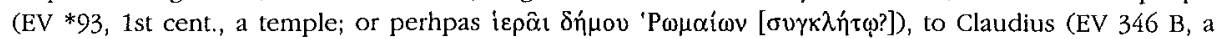
temple), to Claudius, identified with Zeus Soter, and Agrippina, identified with Demeter Karpophoros (EV 248, 252), to Tiberius und Zeus Kapetolios Alseios (EV *135), and to Tiberius (EV *279, by Caligula).

Sanctuaries: A series of boundary stones of the classical period (EV 328,*330-333) name the

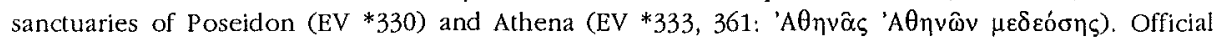


documents were usually inscribed in the sanctuary of the Twelve Gods (ED 54, 73,*190, 4th-3rd cent.) or in the Asklepieion (ED*91,132,134,206, 4th-3rd cent.). A small fragment (ED*125, imp.)

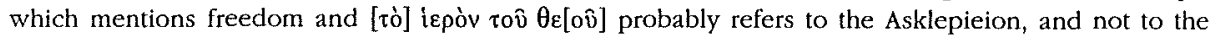
sanctuary of an emperor, as suggested by $S$. Another text (ED*166) probably deals with the construc-

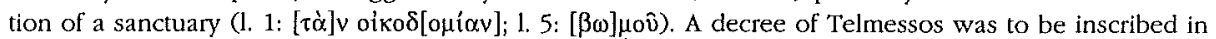
Telmessos in the sanctuary of Artemis (ED 56, 3rd cent.).

Calendar: Koan months: All the names of Koan months are mentioned in texts of this volume: Agrianios (ED *145), Alseios (ED *145,*166, *216), Artamitios (ED *145,*180), Badromios (ED *145, 241), Dalios (ED *145,*178), Gerastios (ED *145, *146,*216), Hyakinthios (ED *145, *180), Kaphisios (ED *145), Karneios (ED *145,*154,*174,*216), Panamos (ED *3,*145,*180), Petageitnyos (ED 149, 241), and Theudaisios (ED *145, 149). ED *3 shows that $\delta$ evirepoc Panamos was the intercalary month on Kos. A few months of other cities are mentioned as well: Anthesterion (ED*31, Halikarnassos?), Artemision (ED 203, in an unknown city), Eleutherion (ED 132, Halikarnassos).

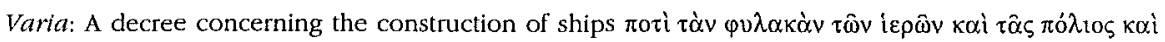
$\tau \hat{\alpha} \zeta \chi \omega \hat{\rho} \alpha[\zeta]$ asks the trierarchoi to apply on the stern and the prow of the ships images of Herakles

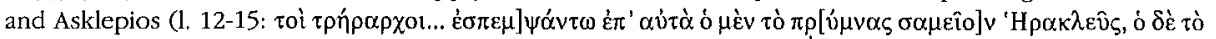

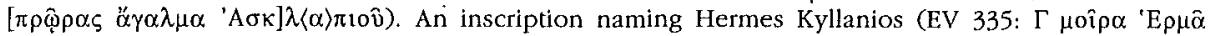
Kv $\lambda \lambda \alpha\langle v\rangle$ ív $)$ is probably related to a part of the city wall set under the protection of the god (according to R. HERzOG). Finally, notice the honorific inscription for Ti. Claudius Alkidamos Ioulianos (EV *224, 1st cent. AD) who was regarded as a descendant of Asklepios (35th generation) and Herakles (50th generation). Such claims are common in Hell. and imperial times (cf. supra on the dedicatory epigram of Philippos, who regarded Herakles his ancestor; for further examples see A. CHANIOTIS, Historie und Historiker in den griecbischen Inschriften, Stuttgart, 1988, p. 225f.). [AC]

*220) B. SERGENT, Les petits nodules et la grande Béotie, in REA, 96 (1994), p. 365-384: S. discusses the question of early Theban domination of large parts of Euboia and Attika, focusing on the Boiotian cults and their origin. [ES]

221) M. SÈve, Les concours d'Épidaure, in REG, 106 (1993), p. 303-328 [BE 1995, 256]: S. reviews what we know about the agons of Epidauros. Although competitions (perhaps dedicated to Apollon) are attested already in archaic times, the Asklepieia are attested only from the 5th cent. $\mathrm{BC}$ on and until the middle of the 3rd cent. $\mathrm{AD}$. The floruit of this agon was in the 4th and 3rd cent. $\mathrm{BC}$; it lost its importance after the 3rd cent. BC due to the rise of the Asklepieia at Kos and Pergamon. The pentaeteric agon included athletic events (for boys and men), equestrian events, and musical competitions; attested are events for rhapsodes, auletai, kitharodes, tragedy, and comedy. The victors received a laurel wreath. S. provides a list of the known victors. [AC]

222) M. SEYER, Die Grabung in den Hangbäusem von Limyra, in Lykien-Symposion, vol. 2, p. 171-181: S. presents a small altar dedicated to Artemis Pergaia found in a domestic context in Limyra (p. 175f., fig. 4) [supra $\mathrm{n}^{\circ}$ 97]; altars of this type were probably used in domestic worship. [AC]

223) K.W. SLANE - M.W. DICKIE, A Knidian Phallic Vase from Corinth, in Hesperia, 62 (1993), p. 483-506 [BE 1994, 143]: Presentation of a moldmade plastic vase of Knidian fabric in the form of a phallus (Korinth, late 2 nd cent. $A D$ ). The self-strangulating figure represented in relief can be iden-

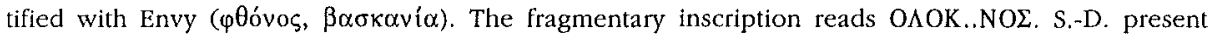
ample evidence for the use of phalluses against the evil eye, apotropaic inscriptions ( $\alpha \pi \varepsilon \tau \rho \tilde{0} \pi \eta \sigma \alpha$,

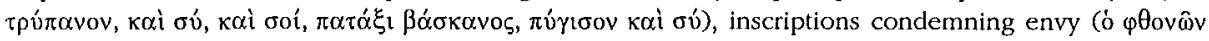

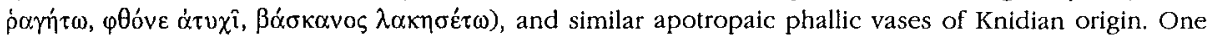
of the latter (CVA, Cracow, Musée Czartoryski [Poland 2], pl. 14, inv. 1239) is inscribed with an apotropaic formula ( $\Sigma \Omega \Sigma I O I K O \Sigma I \Sigma \Pi E T A I X O \Sigma H K A \Lambda H$, a form of $\sigma \omega \sigma i o r k o \zeta)$. The content of the vases is not known. $[\mathrm{AC}]$

224) WJ. SLATER, Three Problems in the History of Drama, in Pboenix, 47 (1993), p. 189-212: The inscription concerning the Sarapieia at Tanagra ( $S E G$ 19, 335, early 1st cent. BC) records among other things indirect expenditures for costumes, fluteplayers, etc. S. argues that this text is no proof for the use of a chorus in performances of old tragedy; the choruses mentioned in the text were for the new tragedies and satyrplays. [AC] 
225) M.F. S MITH, New Readings in the Demostheneia Inscription from Oinoanda, in $A S, 44$ (1994), p. 59-64: On the basis of photographs and squeezes $S$. gives numerous minor new readings of the inscription concerning the organization of the Demostheneia festival at Oinoanda. These, however, bring no substantial changes to the text published by M. WÖRRLE [EBGR 1988, 193]. [AC]

226) R.R.R. SMITH, Aphrodisias 1992, in XV. Kazi Sonuçlari Toplantisi, Ankara 24-28 mayir 1993, Ankara, 1994, vol. II, p. 351-371: An epistylion bearing a dedicatory inscription addressed to (Zeus) Nineudios was rediscovered in Aphrodisias (p. 315, fig. 13). The metrical epitaph for

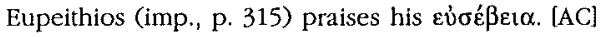

*227) Chr. SOURVINOU-INWOOD, Something to do with Athens: Tragedy and Ritual, in Accounts Lewis, p. 269-290: S. suggests a reconstruction of the different stages of the rituals performed at the Great Dionysia and discusses the development of the tragedy from the sacrificial ritual performed during the xenismos of Dionysos. [ES]

228) A.J. SPAWFORTH, Corinth, Argos, and the Imperial Cult: Pseudo-Julian, Letters 198, in Hesperia, 63 (1994), p. 211-232; addendum, p. 522 [BE 1995, 55]: S. reconstructs the historical setting of a letter of disputed date and authorship preserved in the correspondence of Julian (letter 198). The letter recommends to an unidentified person an Argive embassy, seeking a hearing regarding a dispute with Korinth over Argive payments for the staging of wild-beast shows (venationes) in Korinth. S., following partly B. KEIL, rejects the Julianaic authorship and proposes to date the letter between $\mathrm{AD} 80$ and 120. Thus, the text is an important source for the history of early imperial Achaia. It relates to the cult of the emperors founded by the 'younger' (post $146 \mathrm{BC}$ ) Achaean League in $\mathrm{AD} 54$, to mark the accession of Nero. Combining some epigraphical evidence (IG V 1, 1451; IV 61 ) and 1605) S. shows that the new cult was celebrated at Korinth; C. Iulius Spartiaticus served as the first high priest for life (E.M. SMALLwOOD, Documents illustrating the Pricipates of Gaius, Claudius and Nero, Cambridge, 1967, $\mathrm{n}^{\circ} 264$ ). The financing of the cult eventually provoked a conflict between Korinth and Argos. [ES]

229) J. SPIER, Ancient Gems and Finger Rings. Catalogue of the Collections. The J. Paul Gelty Museum, Malibu, 1992 [BE 1994, 158; SEG 42, 1704, 1705]: The collection includes a gem with the representation of Aphrodite Anadyomene and the inscribed names of Zeus and Ouranos (359: Zev่ Oujpavovi; 2nd/3rd cent.), a gem with the representation of two Tychai with cornucopia and the benediction $\chi \alpha \rho \alpha$. ('joy', 368, 2nd cent. AD), and a gem with the representation of a dolphin and the wish 'vita tibi' $(385,2$ nd $/ 3$ rd cent.). [AC]

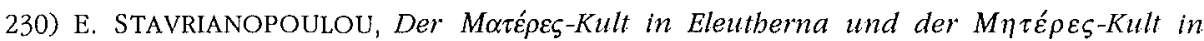
Engyon: Ein gemeinsamer Ursprung, in PP, 48 (1993), p. 161-175 [BE 1994, 63]: A recently published lex sacra from Eleutherna [SEG 41,744; EBGR 1991, 226] attests the cult of Materes in this Cretan city. The identity of these Materes is not clear, and an identification with Demeter and Persephone is not probable. The cult was hitherto known from literary sources. Diodorus, Cicero, and Plutarch mention the Cretan origin of the cult, but locate it in the Sicilian city Engyon, which was believed to be a Cretan colony. The new epigraphic find confirms that the cult existed on Crete and suggest a Cretan origin for the cult in Engyon. In view of the legends about Minos' adventures and death in Sicily, the possibility of close contacts between Crete and Engyon before the age of colonization should not be excluded. [AC]

231) M. STEINBACH - R. WAGMAN, Votive Perirbanteria from Epidauros: Anecdota and Revisions, in $Z P E, 103$ (1994), p. 106-108 [BE 1995, 259]: 1) Ed. pr. of a dedication of a perirrhan-

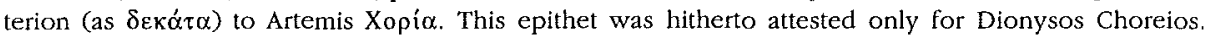
The cult of an Artemis related to choric dances at Epidauros is not surprising, since choruses for Artemis are well attested in the Peloponnese (Sparta, Karyai, Olympia). 2) The inscriptions $I G I^{2} 1$, 191 and $A S A W 63.5$ (1972), p. $8 \mathrm{n}^{\circ} 6$ are two separate dedications to Apollon. Another inscribed perirrhanterion dedicated to Apollon has been found recently [cf. EBGR 1988, 90]. [ES]

232) D. STEINER, Pindar's 'Oggetti Parlanti', in HSCP, 95 (1993), p. 159-180: The statues, stelae, and bases mentioned in Pindar's Odes evoke actual monuments set up for victors of agons or heroes. Just as real monuments, the Pindaric artifacts include inscribed elements, which replicate the content, form, and design of agonistic epigrams. [AC] 


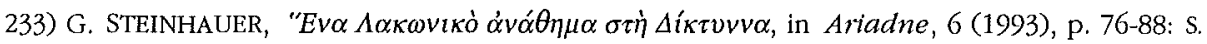
publishes a small column dedicated to Diktynna (Agioi Anargiroi, Lakonia, 4th/3d cent.) and discusses the evidence for the cults of Diktynna in Lakonia. [AC]

234) Frank Sternberg AG, Zürich, Auktionskatalog Nr. 5, September 1993: The catalogue of the auction contains two inscribed magical gems ( 2 nd cent. AD) made of hematite (p. $45, n^{\text {os }} 804-$ 805). $\mathrm{N}^{\circ} 804$ bears on one side a representation of a warrior with a tropaion and on the other the inscription KOMBO/TOPOM. $N^{\circ} 805$ has on the obverse repesentations of scarabs, birds, goats, a crab and a crocodile sorrounding a phoenix seated on an altar; the inscription on the reverse $(\sigma \tau / \mathrm{o} / \mathrm{\alpha} \chi / \mathrm{ov} / \mathrm{F})$ ) shows that the amulet was used against stomach pains (for parallels see supra $\mathrm{n}^{0} 51$ 52]. $[\mathrm{AC}]$

235) C.M. STIBBE, Das Eleusinion am Fuße des Taygetos in Lakonien, in BABesch, 68 (1993), p. 71-106: S. presents the history of the discovery of the Eleusinion at Kalyvia (Lakonia, 8th-4th cent. BC) and the problems related to its topography. Demeter was worshipped there as a goddess of birth. Orpheus and Artemis Bendis were also associated with this cult. In an appendix S. presents the finds of the excavation of 1910 , which include a series of sealed roof tiles ( $n^{\text {os }} 37-42$, all of them published, except for part of $n^{\circ} 42$ with the text $\left.\Delta \alpha \mu[\alpha \tau \rho--]\right)$; the inscriptions on the seals name Demeter. One text was restored by M.P. NILSSON (The Minoan-Mycenaean Religion and its Survival

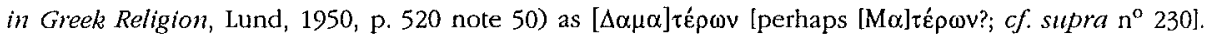
$[\mathrm{AC}]$

236) F. VAN STRATEN, Images of Gods and Men in a Cbanging Society: Self-Identity in Hellenistic Religion, in Self-Definition, p. 248-264: S. studies the interaction between mortals and gods as expressed in the representations (and to some extent in the inscriptions) of Hell. and imp. votive reliefs (dedications, confession inscriptions, etc.). He argues that the closeness between gods and worshippers, which can be observed in the classical reliefs, is followed from the Hell. period on, by a tendency to allocate humans and gods to separate panels or to express little relationship between them. He also considers the dedicatory reliefs of sick persons, dedications after dreams, and reliefs related to the foundation of a sanctuary (e.g., the monument of Telemachos in the Asklepieion of Athens and the sanctuary founded by Artemidoros of Perge on Thera) (on the latter $c f$. F. GRAF, Bemerkungen zur bürgerlicben Religiosität im Zeitalter des Hellenismus, in P. ZANKER - M. WÖRRLE (eds), Stadtbild und Bürgerbild im Hellenismus, München, 1995, p. 107-109]. S. mentions a unpublished inscribed relief from Kyzikos dedicated to Theos Patroa in Copenhagen (p. 253, fig. 11). [AC]

237) C. TANRIVER - S. KÜTÜK, The Katoikia of Daphnous and the Sanctuary of Apollon. Dapbnousios in the Territory of Apollonia ad Rhyndacum, in EA, 21 (1993), p. 99-102 [BE 1995, 468]: Ed. pr. of inscriptions found at Akçapinar (ancient Daphnous), where a previously unknown sanctuary of Apollon Daphnousios existed. The texts consist of an honorific inscription set up in this sanctuary by the inhabitants of Daphnous (1, Hell.), and 5 dedications to Apollon Daphnousios (stelae with relief representations of Apollon kitharodos, 2-6). [AC]

238) P. THEMELIS, Archaeological Reports, in Kretike Hestia, 4 (1991/93), p. 247-257:

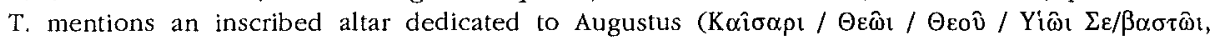
Eleutherna). [AC]

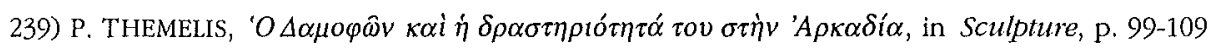
[BE 1995, 88]: A stele with seven honorific decrees for the Messenian sculptor Damophon was found in 1972 in Messene. T. presents the text of a honorific decree of Lykosoura (p. 102, ca. 200/190 $\mathrm{BC}$ ). Damophon appeared before the iєpò $\beta$ ou $\lambda \dot{\alpha}$ of Lykosoura and accepted a request made by the priest of Despoina with regard to money owed to him by the city for previous work (probably the construction of the cult statues in the temple of Despoina); he also agreed to make a statue of Hegemone. Lykosoura honored Damophon with the dedication of his statue in Despoina's sanctuary; the honours were announced at the Nemea, Lykaia, and Ithomaia. (Cf. P. THEMELIS, Damophon von Messene. Sein Werk im Lichte der newen Ausgrabungen, in $A K$, 36 (1993), p. 24-40; see also the remarks of M. SĖVE, in $B E 1994,121 ; 1995,88$ ]. [AC] 


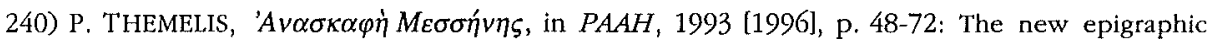
finds in Messene include roof-tiles inscribed with the names of eponymous priests of Zeus Ithomatas (p. 55, 57, 59), an honorific inscription for a Messenian wrestler, boxer, and pankratiast who won victories in 34 agons (Lykaia, Aleaia, Pythia in Megara, Delia in Tanagra, Rhomaia in Aigion and Chalkis, Isthmia, Heraia, Nemea, Panathenaia, Eleutheria in Plataiai, Olympia, Pythia, Eleutheria in Larisa, and Halieia, p. 56f., 2nd cent. AD), an honorific inscription for the high priest of the emperor cult (known also from $I v O 447-448$, p. 57, on the reverse of the pevious text), a new list of kistiokosmoi and prostatai of Athena Kyparissia (p. 60), a fragmentary stele with signs of musical notation

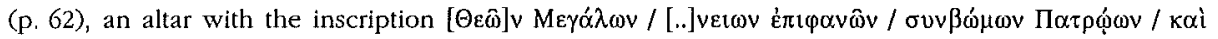

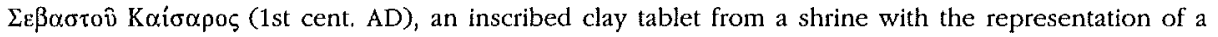

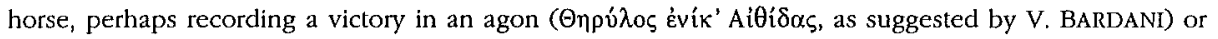
a dedication ('́vík' = ñvike, i.e., 'dedicated', as suggested by Ch. KRITZAS, p. 67f.). [AC]

241) S.V. TRACY, IG II 1195 and Agathe Tyche in Attica, in Hesperia, 63 (1994), p. 241-244 [BE 1995, 227]: T. comments on the date of the decrees (of Athens and of a deme) reconstructed by M.B. WALBANK [infra $\mathrm{n}^{\circ} 268$ ]. The attribution of these texts to a particular cutter and the mention of

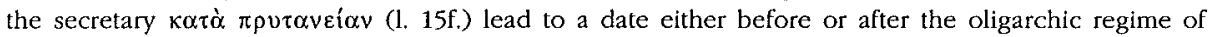
321/0-319/8 BC. The content of the demotic decree, particularly the munificent sacrifices (l. 28-30), indicates an Athenian military success between Alexander's death (June 323) and the battle of Krannon (late summer 322). The second subject of his article is the development of the cult of Agathe Tyche in Athens. Some dedications to Agathe Tyche, jointly with the Twelve Gods or with Dionysos and Zeus, suggest that her cult was already established in the first half of the 4th cent. The cult was fostered by Lykourgos, whose measures (335/4) concern among other things the treasurers and the overseers of the sanctuary of Agathe Tyche. State sacrifices to Agathe Tyche are attested from about this time. The increasing frequency of the words $\alpha{ }^{\gamma} \alpha \theta \dot{\eta} \tau \hat{\eta} \chi \eta$ in inscriptions seems to be related to the rapid development of the cult of Agathe Tyche. An inscription of the 1st cent. BC (IG II ${ }^{2} 1035,1$. 44, 48) mentions two temene of Agathe Tyche, one in Piraeus and another on the outskirts of the city. [ES]

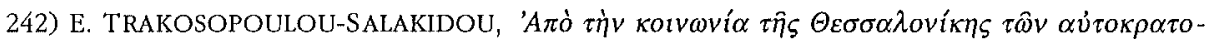

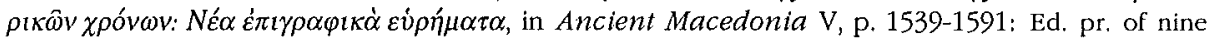
inscriptions from Thessalonike. One of them (1) is dedicated to Isis and records (in Greek and Latin) repairs to her temple and the construction of a $\pi \rho o v$ áiov (pronaium) by a woman (1st cent. AD). A

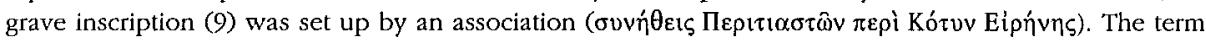

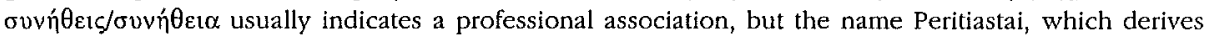
from Peritia, a festival of Dionysos or Hermes, does not exclude the possibility of a cult association (or a combination of the two). The leader of the association can be identified with Kotys, son of

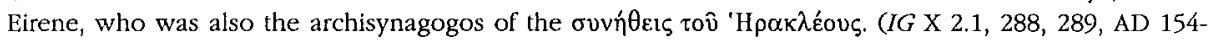
155). $[\mathrm{AC}]$

243) F.F. TROISI, Una piramidetta iscrita da Canosa, in Epigraphica, 56 (1994), p. 196-199: Ed. pr. of a lex sacra written on pyramidal clay object (Canusium, 2nd cent. AD). The text reads: $\beta \lambda \alpha$.

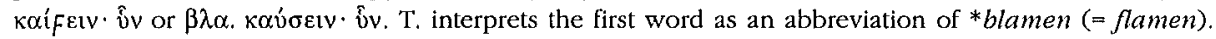
T. relates this text to the cult of Zeus. The cult of Jupiter Pluvialis is attested in a Latin inscription found at the same location. [ES]

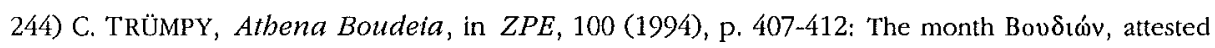

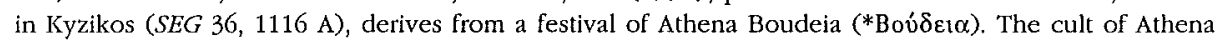
Boudeia is known from Thessaly ( $c f$. the place names Boudeion in Phthiotis and in Boiotia). The epithet of the goddess $\left(<\beta 0 \hat{v} \varsigma+\delta \varepsilon^{\prime}(\omega)\right.$ means 'the goddess who ties up the oxen' and is a synonym of

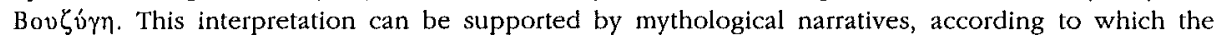
name of Erginos was either Bouzyge or Boudeia, a Boiotian heroine. The month Boudion is a summer month which corresponds to the Attic Metageitnion. The non-Ionian origin of the month Boudion makes it plausible that the population of Kyzikos included a non-Ionian (probably Aiolian) element, which settled there before the colonization of Kyzikos by Miletos. [ES] 
245) G. TSETSKHLADZE, The Interpretation of Picbunari, in DHA, 20.1 (1994), p. 127-145: A stemless bowl found in the Kolchian necropolis bears two graffiti, one of them naming Apollon (late 5th cent. BC). T. sees here an indication for the presence of Ionian settlers at Pichvnari. [ES]

246) G. TSETSKHALDZE, Archaeological Investigations in Georgia in the Last Ten Years and Some Problems of the Ancient History of the Eastern Black Sea Region, in REA, 96 (1994), p. 385-414: T. reports the find of an inscribed bronze plate which will be published by J. VINOGRADOV. [The names of Ge, Helios, and Mes can be read on the photograph]. [ES]

247) M. TÜRKTÜZÜN - M. W ÖRRLE, Eine neue Türgrabstelle aus dem phrygischen Alioi, in Chiron, 24 (1994), p. 95-101 [BE 1995, 570]: Ed. pr. of a funerary inscription (Alioi, early 3rd cent.

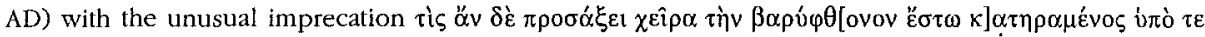
$\Delta i \alpha, \Gamma \hat{\eta} v, " H \lambda_{1 o v}$. The trinity invoked here is not attested as such in the context of funeral imprecations, but it appears in manumission records from Aetolia, Egypt, and the region of Bosporus. The reference to these deities can be explained through the social background of the couple (ex-slaves). [ES]

248) A. TWARDECKI, Weibinschrift für Hermes oder Soucbos?, in $Z P E, 99$ (1993), p. 197-202

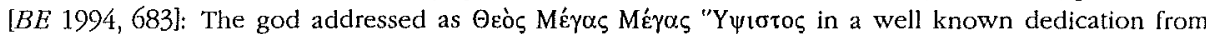
Fayum (29 BC; E. BERNAND, Recueil des inscriptions grecques du Fayoum, Cairo, 1981, 143f; W. HORBURY - D. NOY, Jewish Inscriptions of Graeco-Roman World, Cambridge, 1992, $\mathrm{n}^{\circ} 116$ ) should be identified either with Hermes or with the crocodile-god Souchos-Sobek. The gemination $\mu$ é $\gamma \alpha$, $\mu \varepsilon \dot{\gamma} \alpha \varsigma$ is often attested in connection with the cult of Souchos and should not be associated with the Jewish epanadiplosis. The epithet "Y $\psi 1 \sigma \tau 0$ s was often used in Egypt under Jewish influence, but not always by Jews. This epithet is not attested for Souchos, but it can be explained easily, since in the late Ptolemaic period this god was regarded by his priests as a universal deity, associated also with

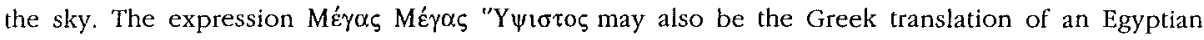
tripartite formula, often attested for Hermes (cf. Hermes Trismegistos). [AC]

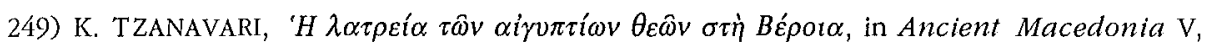
p. 1671-1682: The cult of Isis Lochia in Beroia was known from a dedicatory inscription [SIRIS 107]. T. presents further evidence for the cult of Egyptian deities in the city: two inscribed dedicatory plaques with representations of two footprints (of the right foot) (on the significance of such footprints see $E B G R$ 1990, 77], a statue of Isis, and a statuette of Harpokrates. [AC]

250) A. TZIAFAliAS, in $A D, 44$ Chron. (1989) [1995], p. 233-240: T. reports the discovery of numerous inscriptions in Thessaly. Atrax (p. 238): Hell. dedications to the Nymphs and Dionysos (11) and to Artemis Stratia (15). Larisa (p. 239): A grave stone dedicated to Hermes Chthonios (17); Hell. dedications to Artemis Eileithyia (18), Agathos Theos (19, after a dream), and Leukothea (20). [AC]

251) A. TZIAFALIAS, in $A D, 45$ Chron. (1990) [1995], p. 218-220: New inscriptions from Thessaly. Atrax: A dedication to Poseidon Patragenes $(12,3$ rd cent. $\mathrm{BC})$ and a dedication to an anonymous

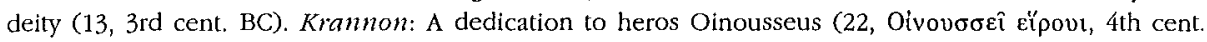
BC). Larisa: A dedication to Zeus Meilichios and Agathe Tyche (25, 1st cent. BC); a grave stone dedicated to Hermes Chthonios (26, 3rd cent. BC). [AC]

252) Y.Z. 'TZIFOPOULOS, Mummius' Dedications at Olympia and Pausanias' Attitude to the Romans, in GRBS, 34 (1993), p. 93-100: PAUSANIAS' statement $(V, 24,4)$ that L. Mummius was the first Roman who dedicated an offering $(\dot{\alpha} v \alpha \dot{\alpha} \theta \eta \mu \alpha)$ in a Greek sanctuary has been regarded as eroneous, since earlier Roman dedications are known. However, what Pausanias meant is that Mummius was the first Roman who dedicated the statue of a god, i.e., two statues of Zeus, and not war-booty, wreaths, or self-portaits. Since Pausanias' aim was to mention the most notable monuments of the Altis, he refers to the dedication of Zeus' statues and 21 gilded shields, but omits, the four statues of Mummius, which the consul dedicated in Olympia (IvO 278-281). [AC]

253) Ch. 'TZOUVARA-SOUl, Common Cults in Epirus and Albania, in L'lllyrie, p. 65-82: The most prominent deity worshipped in both Epirus and Albania is Apollon. From the representation of baetyls on coins and tiles of Ambrakia we may infer that Apollon Agyieus was the protector of the city; baetyls are also known from Apollonia, Orikos, etc. Other cults attested both in Epirus and 
Albania are those of Aphrodite, Artemis, Asklepios, Athena, Dionysos, Herakles, Hermes, the Nymphs, Poseidon, Zeus Boulaios, Zeus Prytanis, Zeus Soter, Zeus Dodonaios, and Dione. The presence of these cults can be the result of the influence of Korinth and its colonies (Ambrakia, Apollonia). [AC]

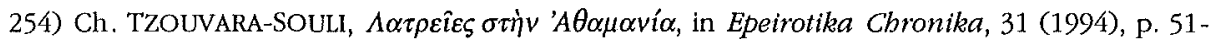
59: $\mathrm{T}$. presents the cults of Athamania, primarily employing the numismatic evidence. The principal cults were those of Apollon, Athena, and Dione; Poseidon (IG IX 1, 690) and Zeus Akraios were also worshipped in this region. These cults are partly common Epirot cults (Dione, Poseidon) and reflect the close relationship of Athamania to the Korinthian colony Ambrakia (Athena, Apollon) and to Thessaly (Zeus Akraios). [AC]

255) E. VARINLIOGLU, Nouvelles inscriptions de Stratonicée, in REA, 95 (1993), p. 533-536: Ed. pr. of four inscriptions from Stratonikeia. Two honorific inscriptions were set up for the deceased benefactor Flavianos $(1,2)$ and one for his wife Aurelia Apphia (4), high priestess of the emperor cult. Flavianos and his wife bequethed to the city money for $\theta \varepsilon \omega \rho i \alpha 1$, probably spectacles. Flavianos

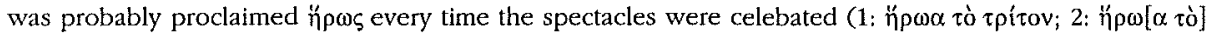

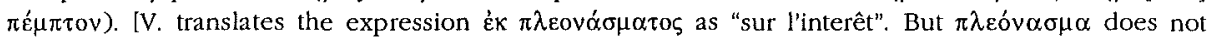
mean 'interest', but 'surplus'. The city dedicated statues from the remaining money, which was not

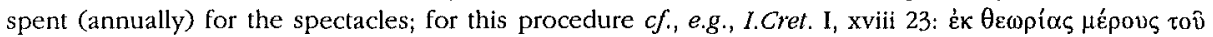

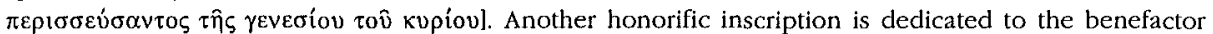
M. Aurelius Antiochos Leon, who also bequethed money for $\theta \varepsilon \omega p i \alpha 1$, on the occasion of the first celebration of the spectacles $(\theta \varepsilon \omega \rho \hat{\omega} v \pi \rho \omega \dot{\tau} \omega \mathrm{v})$. [AC]

256) E. VARINLIOGLU, La fortification bellénistique de Stratonicée, arcbéologie et épigrapbie, in $R E A, 96$ (1994), p. 189-190; Ed. pr. of an inscription (late 3rd cent. BC) referring to the defense

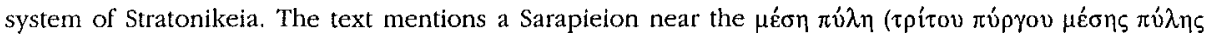

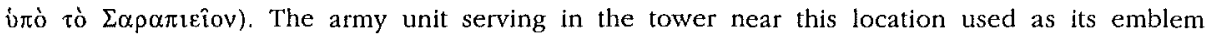

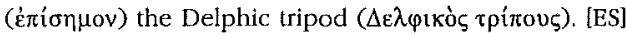

257) C. VATIN, L'offrande des Liparéens à Delphes, in Ostraka, 2 (1993) p. 145-167: V. claims to have seen more traces of letters on the base with the dedication of 20 statues of Apollon by the Lipareans after their victory over the Etruscans ( $c f$. PAUS., X, 11, 3; X, 16, 7; FD III.4, 181-184) and proposes a new restoration of the dedicatory epigrams and the signature of the artist. [AC]

258) Ch. VELIGIANNI, Lex sacra aus Amphipolis, in ZPE, 100 (1994), p. 391-405 [BE 1994, 431]: Ed. pr. of a fragmentary lex sacra concerning the cult of Asklepios in Amphipolis (late 4th cent. BC). The text states the requirements for incubation in the Asklepieion (1. 3 and $7: \dot{\varepsilon} \gamma \kappa \alpha \theta \varepsilon \dot{\delta} \delta \varepsilon v$ ), the payment of one drachme by the visitors of the sanctuary to the priest - in addition to the offering of voluntary sacrifices -, the portion given to the god on the altar ( $\sigma \kappa \varepsilon \dot{\lambda} \eta, \kappa \omega \lambda \varepsilon \alpha \hat{i})$, and the offering of

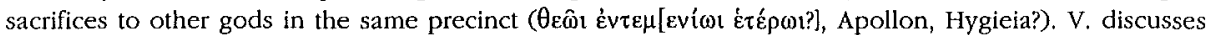
the common cult of Apollon and Asklepios (e.g., in Piraeus, Kos, Epidauros, Beroia, Thermos, Thasos, and Pergamon) and the prominence of the cult of Asklepios in Amphipolis and, generally, in Macedonia, where the priests of Asklepios were (often?, always?) the eponymous officials of cities [on this issue see $E B G R$ 1990, 4]. She suggests that the priest of Asklepios became the eponymous of Amphipolis under Philip II, who probably enhanced this cult. [ES]

259) B. VIRGILIO, Gli Attalidi di Pergamo. Fama, eredità, memoria (Studi Ellenistici, 5), Pisa, 1993 [ $B E$ 1994, 481]: V. studies several aspects of Attalid rule in Pergamon, particularly its reception by contemporaries and in later times. Among other aspects discussed in the book I single out the discussion of the honorific decree of Pergamon concerning the establishment of the cult of Attalos III in the Asklepielon, after a victorious campaign (I.Pergamon 246; p. 23-27); this cult continued even after the end of Attalid rule, at least until the first quarter of the 1st cent. $\mathrm{BC}$; $\mathrm{V}$. shows the discrepancies between the official celebration of Attalos III and the hostile popular tradition. V. also discusses the establishment of the Nikephoria (p. 32f., 85-92), the dedications of and festivals for the Attalids at Delphi and Delos (p. 35-39, 53-55), the cult of Apollonis, the wife of Attalos I, in Hierapolis, Teos, and Kyzikos, and the way her cult served as a model for the association of prominent Roman women with goddesses (p. 45-51), the carreer of Diodoros Pasparos (p. 77-99), for 
whom a temenos was established in Pergamon (1st cent. BC), and the antiquarian interest in mythological and historical tradition in Hadrianic times (p. 114-121). [AC]

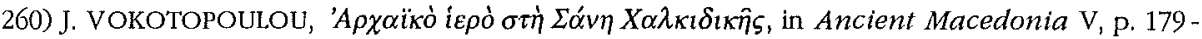
236: A new archaic sanctuary has been excavated in Sane (Chalkidike, 7th-4th cent. BC). The finds indicate a cult of a fertility goddess and the performance of night rituals. Two sherds are inscribed, one with the name of a woman, the other with the epithet of the goddess: $\tau \hat{\alpha} \varsigma \Pi \nu \theta[---]$. The goddess can be identified with Artemis Pythia (rather than Aphrodite Pythonike) [Cf. SEG 42, 624; EBGR 1991, 267]. [AC]

261) I. VOKOTOPOULOU, in $A D$, 45 Chron. (1990) [1995], p. 314-317: During the excavations of an archaic sanctuary at Posidi (Poseidion, Chalikide) vases dedicated to Poseidon were found (5th

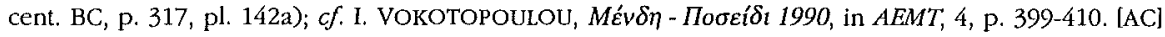

262) I. V OKOTOPOULOU, Mloбeí $\delta t$ 1991, in $A E M T, 5$, p. 303-318 [BE 1994, 427]: New inscribed vases were found in the sanctuary of Poseidon in Posidi; one of them is the dedication of Zenothemis (pl. 14, late 6th cent. BC). [AC]

263) 1. V OKOTOPOULOU - E. TRAKOSOPOULOU, in $A D$, 45 Chron. (1990) [1995], p. 318-319 [BE 1994, 428]: Excavations at Parthenonas Sithonias (Chalikide) have brought to light a sanctuary ( 7 th-3rd cent. BC); several vases were inscribed. The name of the deity may be read on one of them

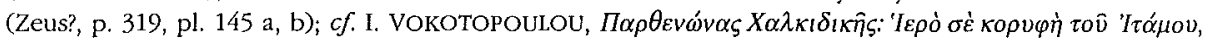
in $A E M T, 4$, p. 425-438). [AC]

264) E. VOUTIRAS, 'H $\lambda \alpha \tau \rho \varepsilon i ́ \alpha$ V, p. 251-265 [BE 1994, 379]: The earliest testimonia for the cult of Asklepios in Macedonia date to the 4th cent. BC, when Asklepieia are attested in Antisara near Kavala, Amphipolis [cf. supra $\mathrm{n}^{\circ}$ 258], and Dion. In later periods Asklepieia are know in Morrylos, Thessalonike, Beroia, Kassandreia, Antigoneia (?), Kalindoia, and Mieza. The priests of Asklepios were eponymous in Kalindoia, Amphipolis, and Mieza [ $f$. EBGR 1990, 4]. The close relationship of Perdikkas III to the Asklepieion of Epidauros suggests that the cult of Asklepios was promoted in Macedonia by the Temenid kings. $[\mathrm{AC}]$

265) R. WAGMAN, An Inscribed Perimbanterion from Epidauros, in $P P, 48$ (1993), p. 394-395 [BE 1994, 173]: An inscribed perirrhanterion found in Epidauros (SEG 33, 386) is identical with IG $\mathrm{IV}^{2}$ 249. [AC]

266) R. WAGMAN, Restorations on the Epidaurian Hymns, in ZPE, 103 (1994), p. 101-102 [BE 1995, 257; SEG 42, 294]: W. proposes emendations to several passages in hymns found in the Asklepieion of Epidauros (3rd cent. AD) [cf. EBGR 1989, 12; 1992, 239 and 241]: IG IV ${ }^{2}$ 129 1. 3, 5; 134 1. 5, 7; SEG 30, 390 1. 11. [ES]

267) R. WAGMAN, Un devoto del dio Sole ad Epidauro, in ZPE, 103 (1994), p. 103-105 (BE 1995, 258]: Ed. pr. of a dedication to Asklepios Soter and Helios Ktistes (Epidauros, AD 166). The dedicant, Seleukos, a descendant of Herakles, had served as priest of this cult for one year. W. identifies him with Seleukos, who made a dedication Helios Pangonos in Epidauros (IG IV ${ }^{2}$ 529). [ES]

268) M.B. WALBANK, A Lex Sacra of the State and of the Deme of Kollytos, in Hesperia, 63 (1994), p. 233-240 [BE 1995, 226]: Ed. pr. of four fragments (fr. a, d, e, f) found in the Athenian Agora, which W. identifies as part of $I G \mathrm{II}^{2} 1195$ (fr. $c=L S C G$ 38) found on the Akropolis, which includes the final clauses of a decree of the Athenian state, followed by the opening clauses of a decree of the deme Kollytos; a further fragment from the Akropolis (IG $\mathrm{II}^{2} 620$, fr, b) almost certainly belongs to the same stele, although it does not join with any of the other fragments. The reconstructed stele contained an Athenian decree and a decree of Kollytos. The decree of the deme provides for sacrifices to all their gods and heroes and above all to Agathe Tyche for the safety of the city. Presumably the state decree referred specifically to the deme Kollytos or to sanctuaries within that deme. The place called Moulseion] (1. 5f.) may be the site of the sanctuary of Agathe Tyche, the primary recipient of the sacrifices (1. 28-30). The appeal to individuals (1. 30f.) to lend money to the deme so that it could finance these sacrifices in some ways reminds us of the measures taken by Lykourgos in 338/7 BC. W. argues, that despite the use of the verb $\delta \alpha v \varepsilon i \zeta \varepsilon i v$ (1. 31), the loans made by 
the citizens of Kollytos may actually have been interest free. The restoration of an archon formula

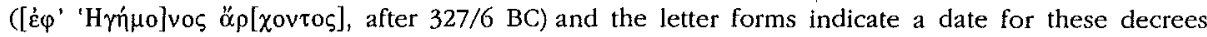
probably in the 320 's, rather than in the 310 's. Although the decrees postdate Lykourgos, they still reflect the spirit of his era. [On this text $c f$. supra $\mathrm{n}^{\circ} 241 ; c f$. the remarks of Ph. GAUTHIER, in BE 1995, 226 ]. [ES]

269) D. WHITEHEAD, The Kolokratai of Kydantidai and Ionidai, in $Z P E, 95$ (1993), p. 159-162 [BE 1994, 297]: Discussion of the common decree of the Attic demes of the Kydantidai and Ionidai

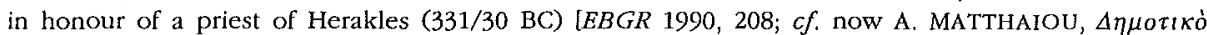

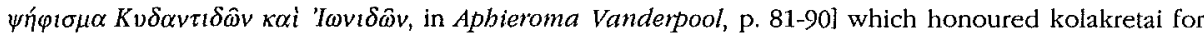

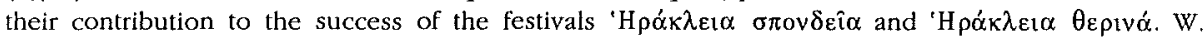
disagrees with A. MATTHAIOU's interpretation of the office of the kolakretai (city magistracy, originally with a religious function, later with financial duties). He suggests that the kolakretai honoured here are local officials of demes Kydantidai with financial duties "with religious overtones". [AC]

270) D. WILliams, Aegina, Aphaia Tempel. XVIII. The Laconian Pottery, in AA, 1993, p. 571598: W. presents the archaic Lakonian pottery found in the temple of Aphaia on Aigina. Three vases bear dedicatory graffiti: an Etruscan inscription (p. $575 \mathrm{n}^{\circ}$ 11) [see supra $\mathrm{n}^{\circ} 123$ ], a dedication to Aphaia (p. $578 \mathrm{n}^{\circ}$ 5), and the dedication of Graphiadas (p. $\left.579 \mathrm{n}^{\circ} 12\right)$. [AC]

271) M. WÖRRLE, $Z$ u den Inschriften von der Südfassade des Stadions, in AA, 1993, p. $446-$ 448: Preliminary presentation of EBGR 1992, $244 \mathrm{n}^{\circ} 2$. [AC]

272) M. WÖRRLE, Zur Weihinscbrift der Brücke 4, in $A A, 1993$, p. 487-489: Preliminary presentation of $E B G R$ 1992, $244 \mathrm{n}^{\circ} 1$. [AC]

273) M. WÖRRLE, Perikles von Limyra. Endlich etwas mebr Griechisches, in LykienSymposion, vol. 1, 187-190: W. presents a metrical dedication of an altar to Zeus by the Lykian dynast Perikles (Limyra, early 4th c. BC) [now fully published: see EBGR 1991, 278]. [AC]

274) M. WÖRRLE, Eine verschwundene Inschrift von Limyra, in Erforschung Kleinasiens, p. 357-362: W. presents a decree of the Pernitai with an imprecation. For publication and commentary see M. WÖRRLE, Epigraphische Forschungen zur Gescbichte Lykiens IV. Drei griechische Inscbriften aus Limyra, in Cbiron, 21 (1991), p. 203-239 [EBGR 1991, 278]. [AC]

*275) M. YON, Héraclès à Cbypre, in Héraclès, p. 145-163: The worship of Herakles is well attested on Cyprus, but the evidence lacks a homogeneity. While part of the iconographic evidence shows that the Cypriotes were familiar with the panhellenic image of Herakles, in Kition Herakles was worshipped as a young god, closely related to the Phoenician Melgart ( 5 th- 4 th cent.). Theophoric names related to Herakles are common in Kition (p. 157f.); in a bilingual inscription, Herakleides appears as the Greek translation of the Phoenician name Abdmelqart, confirming the identification of Herakles with Melqart. [AC]

276) K. ZACHOS, in $A D, 45$ Chron. (1990) [1995], p. 257-258 [BE 1995, 290]: Two honorific inscriptions from Nikopolis for two runners who won the stadion-race in the age-class of boys at the Megala Aktia (8, on the 19th celebration of the agon) and at an agon in Larisa (9) $\left[=\operatorname{supra~}^{\circ} 62\right]$. $[\mathrm{AC}]$

277) F. ZEVI - M.L. LAZZARINI, Hydria bronzea da Pompei, in $A S M G$, 3rd Ser., 1 (1992), p. 91 97 [BE 1993, 709; SEG 42, 921]: A bronze hydria found in the house of C. Iulius Polybius in Pompei was according to an inscription the prize of a victor in the Heraia of Argos (ca. 460/450 BC). [AC]

278) R. ZIEGLER, Aigeai, der Asklepioskult, das Kaiserhaus der Decier und das Christentum, in Tycbe, 9 (1994), p. 187-212: Combining the numismatic and the epigraphic evidence Z. studies the history of Aigeai (Kilikia) in the 2nd and 3rd cent. AD. The cult of Asklepios and Hygieia is epigraphically attested from the late Hellenistic period on. The Asklepieion, which was granted the right of asylia, was as renowned as the Asklepieia in Epidauros, Kos, and Pergamon. Under the Decii the city received the epithet Asklepioupolis. [ES] 
279) M. ZIMMERMANN, Neue Inscbriften aus Kyaneai und Umgebung II, in F. KOLB (ed.), Lykische Studien 1. Die Siedlungskammer von Kyaneai (Asia Minor Studien, 9), Bonn, 1993, p. 139-150 [BE 1994, 548]: Ed. pr. of a bilingual (Lykian-Greek) grave inscription (5, 4th cent. BC)

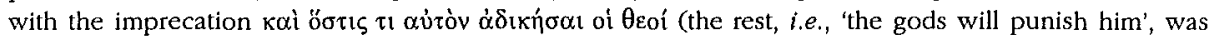
not inscribed). Ed. pr. of a relief with representation of the Twelve Gods, dedicated to Artemis Kynegetis and the Twelve Gods (8, no date) Ion the Lykian Twelve Gods cf, supra $\mathrm{n}^{\circ}$ 84; see also B. FREYER-SCHAUENBURG, Die lykischen Zwölfgötterreliefs (Asia Minor Studien, 13), Bonn, 1994]. [AC]

280) S. Z OUMBAKI, Zu einer neuen Inschrift aus Olympia: Die Familie der Vettuleni von Elis, in ZPE, 99 (1993), p. 227-231: A new fragment permits the restoration of an inscription recording the victory of Cassia, the daughter of M. Vettulenus Laetus, in the quadriga race (IVO 233). Cassia won this victory in the 200th Olympic Festival (AD 21), and not in the 2nd cent. AD. On the basis of this restoration $Z$. discusses the history of the prominent family of the Vettuleni in Elis. [AC]

281) R. ZUCCA, Il complesso epigrafico rupestre della "Grotta delle Vipere", in Rupes loquentes, p. 503-540: Z. gives a new edition (with new readings) of the rock-inscriptions in the cave "Grotta delle Vipere" in Sardinia ( $C I L$ X 7563-7578, 1st cent. AD), which was used as the heroon (CIL X 7578: vๆ[óls) of L. Cassius Philippus and his wife Atilia Pomptilla, who followed her husband in exile in Sardinia, and died after living with him for 42 years. Philippus composed after her death a series of Greek and Latin epigrams expressing his love and his sorrow. Pomptilla, who seems to have

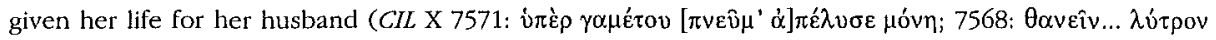

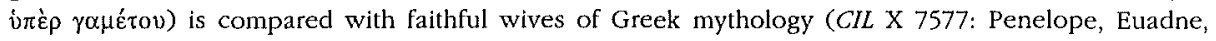
Laodameia, Alkestis).

\author{
Angelos CHANIOTIS \\ Department of Classics \\ New York University \\ 25 Waverly Place \\ NEW YORK, N.Y. 10003 \\ U.S.A. \\ e-mail: chaniots@is2.nyu.edu
}

\section{Eftychia STAVRIANOPOULOU}

Seminar für Alte Geschichte

Universität Heidelberg

Marstallhof 4

69117 HEIDELBERG

Germany 